\title{
Hole U1415I
}

K.M. Gillis, J.E. Snow, A. Klaus, G. Guerin, N. Abe, N. Akizawa, G. Ceuleneer, M.J. Cheadle, Á. Adrião, K. Faak, T.J. Falloon, S.A. Friedman, M.M. Godard, Y. Harigane, A.J. Horst, T. Hoshide, B. Ildefonse, M.M. Jean, B.E. John, J.H. Koepke, S. Machi, J. Maeda, N.E. Marks, A.M. McCaig, R. Meyer, A. Morris, T. Nozaka, M. Python, A. Saha, and R.P. Wintsch²

\section{Chapter contents}

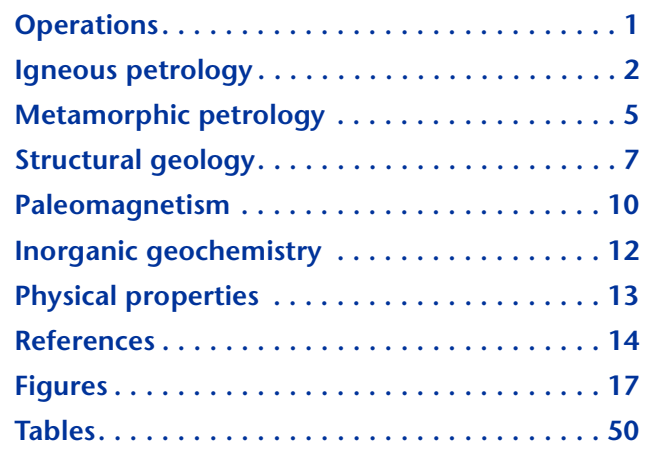

'Gillis, K.M., Snow, J.E., Klaus, A., Guerin, G., Abe, N., Akizawa, N., Ceuleneer, G., Cheadle, M.J., Adrião, Á., Faak, K., Falloon, T.J., Friedman, S.A., Godard, M.M., Harigane, Y., Horst, A.J., Hoshide, T., Ildefonse, B., Jean, M.M., John, B.E., Koepke, J.H., Machi, S., Maeda, J., Marks, N.E., McCaig, A.M., Meyer, R., Morris, A., Nozaka, T., Python, M., Saha, A., and Wintsch, R.P., 2014. Hole U1415I. In Gillis, K.M., Snow, J.E., Klaus, A., and the Expedition 345 Scientists, Proc. IODP, 345: College Station, TX (Integrated Ocean Drilling Program).

doi:10.2204/iodp.proc.345.109.2014

'Expedition 345 Scientists' addresses.

\section{Operations}

The location for Integrated Ocean Drilling Program (IODP) rotary core barrel (RCB)-cored pilot Hole U1415I (see Fig. F8 in the "Expedition 345 summary" chapter [Gillis et al., 2014b]) was selected using $3.5 \mathrm{kHz}$ data that indicated a thin sediment cover and bottom images that showed a flat-lying sedimented seafloor free of rock fragments. Hole operations are summarized in Table T1 and outlined below. All times are ship local time (UTC $-7 \mathrm{~h}$ ).

\section{Near-bottom camera survey}

At the end of operations in Hole $\mathrm{U} 1415 \mathrm{H}$ and while still at that location, we deployed the camera system without the $3.5 \mathrm{kHz}$ pinger and moved the ship $\sim 50 \mathrm{~m}$ northwest to the next potential site for a pilot hole. Once on location, a brief visual survey was conducted with the subsea camera confined to a $\sim 5 \mathrm{~m}$ radius around the target coordinates (see Table T1 and Fig. F3 in the "Bench site survey" chapter [Gillis et al., 2014a]). The area appeared to be relatively free of boulders or any indications of rubble.

\section{Drilling operations}

After the camera system was recovered, we started Hole U1415I at $1110 \mathrm{~h}$ on 28 December 2012. Drilling proceeded much the same as in Hole $\mathrm{U} 1415 \mathrm{H}$, albeit with a slower rate of penetration (ROP). After penetrating $\sim 6 \mathrm{~m}$, drilling was halted, the drill string was picked up a few meters off bottom, and the circulating pumps were reduced. This initial test indicated that the hole was remaining stable. The test was repeated the following morning at $\sim 9$ meters below seafloor (mbsf) with the same result, although once back on bottom, the drilling torque temporarily increased slightly as if something was being ground up below the bit. Associated with this increase in torque was an increase in ROP from 0.4 to $0.8 \mathrm{~m} / \mathrm{h}$. Slow penetration rates were to be expected, given that we were applying very light weight on bit $(5000 \mathrm{lb})$, as the majority of the bottom-hole assembly (BHA) was still unsupported above seafloor. By mid-morning on 29 December, enough penetration had been achieved to allow the core barrel to be recovered and a drill pipe connection to be attempted. We deployed the sinker bars and recovered Core 345-U1415I-1R at $0945 \mathrm{~h}$ on 29 December. The core contained $0.16 \mathrm{~m}$ of gabbroic rock from 0 to 11.7 mbsf. A drill pipe connection was made, the bit was run back 
to bottom, and coring resumed after circulating $\sim 3.0$ $\mathrm{m}$ of fill out of the bottom of the hole.

RCB coring continued in Hole U1415I to 35.2 mbsf under challenging borehole conditions. Cores $1 \mathrm{R}$ through $4 \mathrm{R}$ extended from 0 to $35.2 \mathrm{mbsf}$, with 7.12 $\mathrm{m}$ of recovered core. The overall recovery includes three sections of coarse sand-sized gabbro particles (Sections 345-U1415I-3R-1, 3R-2, and 3R-3). One interpretation of these sand-sized particles is that they are simply cuttings. Alternatively, later examination showed them to be more highly altered and fractured gabbroic material than the recovered core, suggesting that we might have been drilling through a zone of cataclasis. We spent many hours attempting to stabilize the hole with mud sweeps and wiper trips so that we could hang the drill pipe off at the rig floor to deploy a free-fall funnel (FFF), but we were unable to get the bit below 8 mbsf. We eventually abandoned the effort to deploy a FFF because of the excessive risk to the BHA. We pulled the bit out of the seafloor and retrieved a core barrel (Core 5G) that contained $0.21 \mathrm{~m}$ of gabbroic rock inferred to have come from no deeper than $\sim 5$ mbsf. The RCB coring assembly was changed out for a $143 / 4$ inch tricone drilling assembly and deployed back to the seafloor. When the camera system reached bottom, we easily found the mound of cuttings around Hole U1415I; however, the hole appeared to have collapsed, precluding a bare-hole reentry. We decided to abandon Hole U1415I and drill a new hole nearby instead.

\section{Igneous petrology}

Coring in Hole U1415I recovered 25 lithologic intervals and 4 intervals of ghost cores. Table T2 lists these lithologic intervals and their division into two lithologic units. Principal lithologies recovered from Hole U1415I are shown in Figure F1. The upper three sections (345-U1415I-1R-1 through 1R-3) are interpreted as surficial rubble (Unit I). This includes eight lithologic intervals comprising 10\% olivine gabbro and $7 \%$ gabbro (using principal rock names only). The remaining $83 \%$ of Unit I is drilling-induced disaggregated gabbro (gabbroic sand). Unit I overlies an interval of massive gabbro including a $1.1 \mathrm{~m}$ thick layered sequence, defined as Unit II, the Layered Gabbro Series (Sections 345-U1415I-4R-1 through $4 \mathrm{R}-2)$. Unit II is composed of olivine gabbro (39\%), gabbronorite $(27 \%)$, troctolite $(26 \%)$, and gabbro (8\%). The lowermost core from Hole U1415I (Core 345-U1415I-5G) was a "ghost" core recovered during hole cleaning operations from an interval that was previously cored. Analyses of cored rocks of Hole U1415I (two orthopyroxene-bearing olivine gabbro pieces, one olivine-bearing gabbro piece) revealed primitive compositions with $\mathrm{Mg} \#$ (cationic $\mathrm{Mg} /[\mathrm{Mg}$ $+\mathrm{Fe}]-$ all $\mathrm{Fe}$ as $\mathrm{Fe}^{2+}$ ) varying between 81.0 and 82.1 (see "Inorganic geochemistry").

\section{Olivine gabbro}

\section{Olivine gabbro}

Olivine gabbro comprises four lithologic intervals, three as recovered intervals (Intervals 10, 13, and 17) within the layered gabbro sequence of Unit II and one piece from the ghost core (Interval G1; Table T2). The olivine gabbro is medium- to coarse-grained seriate to equigranular granular rock with well-developed magmatic foliation (Figs. F2, F18, F20A). The strong foliation is defined by the alignment of tabular plagioclase (see "Structural geology"). As illustrated by Thin Section 21 (Sample 345-U1415I-4R-1, $35-38 \mathrm{~cm}$ [Piece 6]), olivine gabbro consists of olivine $(5 \%-25 \%)$, plagioclase $(50 \%-70 \%)$, and clinopyroxene $(10 \%-40 \%)$, with trace amounts of oxide and occasionally orthopyroxene (Fig. F18B-F18E). Olivine is fine grained, subhedral to anhedral, and often elongated with an irregular amoeboid habit. Despite their irregular habit, however, the long axes of the olivines are generally parallel to the foliation defined by the plagioclase in the gabbroic matrix. Plagioclase is fine grained and subhedral to euhedral with a tabular habit. Zoning in the plagioclase is variable. The presence of $120^{\circ}$ triple junctions between plagioclase grains indicates that the plagioclase framework is close to textural equilibrium. Clinopyroxene is medium to coarse grained and anhedral with an irregular interstitial to oikocrystic habit.

\section{Orthopyroxene-bearing olivine gabbro}

Orthopyroxene-bearing olivine gabbro is found in four intervals (Interval 3 in Unit I and Intervals 12, 14 , and 20 in Unit II) (Table T2). In general, the orthopyroxene-bearing olivine gabbro is a mediumgrained equigranular granular rock. Two thin sections were cut from Interval 3: Thin Section 13 (Sample 345-U1415I-2R-1, 25-31 cm [Piece 7]) and Thin Section 14 (Sample 2R-1, 51-53 cm [Piece 11]). Modally, orthopyroxene-bearing olivine gabbro consists of olivine $(5 \%-12 \%)$, plagioclase $(50 \%-65 \%)$, clinopyroxene $(20 \%-40 \%)$, and orthopyroxene $(1 \%-4 \%)$, with trace amounts of oxide. Olivine is fine grained and subhedral to anhedral with an equant to subequant habit. Plagioclase is medium grained and euhedral to anhedral with a tabular habit. Intervals in the layered gabbro sequence display well-developed magmatic foliation, defined by the alignment of tabular plagioclase (see "Structural geology"). Clinopyroxene is medium to coarse grained and an- 
hedral with an irregular interstitial and sometimes oikocrystic habit. Orthopyroxene is euhedral to subhedral with a subequant to equant, prismatic or interstitial habit.

\section{Anorthositic olivine gabbro}

Anorthositic olivine gabbro in Interval 9 (Table T2) is a medium-grained poikilitic granular rock with olivine $(5 \%)$, plagioclase $(80 \%)$, clinopyroxene $(15 \%)$, and trace amounts of oxide.

\section{Troctolite and clinopyroxene oikocryst- bearing troctolite}

Troctolite occurs in Interval 18 as part of the layered gabbro sequence in Unit II (Section 345-U1415I-4R1) (Fig. F3). Two thin sections were cut for microscopic observation: Thin Section 19 (Sample 345U1415I-4R-2, 9-13 cm [Piece 2]; Table T3) and Thin Section 24a/24b (Sample 5G-1, 12-14 cm [Piece 3]). Clinopyroxene oikocryst-bearing troctolite occurs in Interval 24 as part of the layered gabbro sequence in Section 4R-2 (Fig. F4) as well as a single piece recovered from Section 5G-1 (Interval G3). The troctolite and clinopyroxene oikocryst-bearing troctolite is medium-grained equigranular rock with well-developed magmatic modal layering and foliation. The strong foliation is formed by the alignment of tabular plagioclase (Fig. F4; see also "Structural geology"). Troctolite consists of olivine (20\%-40\%) and plagioclase (55\%-70\%), with trace amounts of oxide (possibly Cr-spinel) and orthopyroxene. Olivine is fine grained and subhedral to anhedral with an elongated, irregular amoeboid habit (Fig. F21B, F21C). Despite their irregular habit, the long axes of the olivines are generally parallel to the foliation defined by the plagioclase in the troctolitic matrix. Plagioclase is fine grained and subhedral to euhedral with a tabular habit. Overall, plagioclase shows no obvious zoning. Clinopyroxene is sometimes present in the troctolite either as a minor interstitial component (4\%-5\%), ophitic to plagioclase and olivine, or sometimes as thin films between plagioclase and olivine. Although the clinopyroxene is interstitial, alignment of the longer axes of clinopyroxene is generally parallel to the foliation of the troctolitic matrix.

Some troctolite contains large anhedral clinopyroxene oikocrysts (as large as $15 \mathrm{~mm}$ in diameter) that have a distinct population of subhedral to euhedral lath-shaped resorbed plagioclase chadacrysts (Figs. F4, F21). Where these are present, troctolite is referred to as clinopyroxene oikocryst-bearing troctolite (see "Igneous petrology" in the "Methods" chapter [Gillis et al., 2014e]). Olivine is conspicuous by its absence as a chadacryst. The plagioclase chadacrysts are oriented in a random manner within the oikocryst, in sharp contrast to the surrounding foliated plagioclase fabric.

\section{Gabbro}

\section{Gabbro}

Gabbro was described in Intervals 2 and 8 from Unit I as a medium-grained equigranular granular rock (Fig. F5). Thin Section 18 (Sample 345-U1415I-3R-4, $16-19 \mathrm{~cm}$ [Piece 2]) shows that the gabbro consists of plagioclase (50\%-60\%) and clinopyroxene (40\%$50 \%)$, with trace amounts of orthopyroxene. Plagioclase is medium grained and subhedral to euhedral with a tabular habit. Clinopyroxene is medium to coarse grained and anhedral with an interstitial to oikocrystic habit.

\section{Olivine-bearing gabbro}

Olivine-bearing gabbro comprises Interval 23 as part of the layered gabbro sequence in Unit II. The olivine-bearing gabbro is a medium-grained equigranular granular rock. Modally, olivine-bearing gabbro consists of olivine (2\%), plagioclase $(68 \%)$, and clinopyroxene (30\%), with trace amounts of oxide. Olivine is fine grained and subhedral to euhedral with a subequant habit. Plagioclase is medium grained and subhedral to euhedral with a tabular habit. Clinopyroxene is fine to medium grained and anhedral with an irregular interstitial habit.

\section{Anorthositic gabbro}

Anorthositic gabbro defines two intervals in Hole U1415I: Interval 25 from the layered gabbro sequence in Unit II and one piece from ghost Core $5 \mathrm{G}$ (Section 345-U1415I-5G-1; Interval G4). Anorthositic gabbro is medium-grained equigranular to seriate granular rock. This interval displays strong foliation defined by tabular plagioclase crystals similar to the layered gabbros in Unit II. Modally, anorthositic gabbro consists of plagioclase (80\%) and clinopyroxene (20\%). Plagioclase is medium grained and subhedral to euhedral with a tabular habit. Clinopyroxene is medium to coarse grained and anhedral with an interstitial to subequant habit.

\section{Orthopyroxene-bearing gabbro}

Orthopyroxene-bearing gabbro defines Interval 1 at the top of Unit I. This orthopyroxene-bearing gabbro is a medium-grained equigranular granular rock. Modally, orthopyroxene-bearing gabbro consists of plagioclase $(70 \%)$, clinopyroxene $(26 \%)$, and orthopyroxene $(4 \%)$, with trace amounts of olivine (Thin Section 11; Sample 345-U1415I-1R-1, 1-4 cm [Piece 1]). Plagioclase is medium grained and subhedral to 
anhedral with a tabular habit. Clinopyroxene is medium to coarse grained and subhedral to anhedral with an irregular to subophitic habit. Orthopyroxene is anhedral and has an irregular habit.

\section{Gabbronorite}

\section{Olivine-bearing gabbronorite}

Olivine-bearing gabbronorite defines four intervals (Intervals 11, 16, 19, and 21) from the layered gabbro sequence of Unit II. The olivine-bearing gabbronorite is medium-grained equigranular granular rock with a well-developed magmatic foliation (Fig. F6; see also "Structural geology"). The strong foliation is formed by the alignment of tabular plagioclase, similar to that displayed by troctolite. One thin section was cut for microscopic observations (Thin Section 22; Sample 345-U1415I-4R-1, 48-50 $\mathrm{cm}$ [Piece 8A]). Modally, olivine gabbronorite consists of olivine $(5 \%-10 \%)$, plagioclase $(55 \%-60 \%)$, clinopyroxene (20\%-25\%), and orthopyroxene (5\%$15 \%)$. Olivine is fine grained and subhedral to anhedral with an irregular amoeboid habit. Plagioclase is medium grained and subhedral to euhedral with a tabular habit. Clinopyroxene is medium grained and subhedral to anhedral with an equant habit. Orthopyroxene is subhedral to euhedral with a subequant habit.

\section{Gabbronorite}

Gabbronorite was observed in Interval 22 in Section 345-U1415I-4R-2. The gabbronorite is medium grained with a seriate and poikilitic-granular texture. Thin Section 23 (Sample 345-U1415I-4R-1, 136-139 $\mathrm{cm}$ [Piece 12]) was cut for microscopic observations. Modally, gabbronorite consists of plagioclase (50\%), clinopyroxene (40\%), and orthopyroxene (10\%), with trace amounts of oxide. Plagioclase is medium grained and subhedral to euhedral with a tabular habit. Clinopyroxene is medium grained and anhedral with an irregular to poikilitic habit. Orthopyroxene is anhedral with an irregular to equant habit.

\section{Drilling-induced disaggregated gabbro}

Drilling-induced disaggregated gabbro was recovered in Sections 345-U1415I-3R-1 through 3R-3 and most of 3R-4 (Intervals 4-7) and is included in Unit I. Point counting of grain mounts under a petrographic microscope revealed that this gabbro is $\sim 75 \%$ altered. A reconstructed primary igneous mode based on the characteristic alteration assemblages of olivine, plagioclase, and pyroxenes is plagioclase (61\%), clinopyroxene (31\%), and olivine (8\%), corresponding to olivine gabbro (Table T4; see "Metamorphic petrology" for details of reconstruc- tion). The reconstructed modes are consistent with that obtained from olivine-bearing gabbro recovered from Hole U1415I in general.

\section{Layered Gabbro Series of Unit II}

Core 345-U1415I-4R recovered an exceptional series of coherent layered gabbroic rock with a total curated length of $1.1 \mathrm{~m}$ and consisting of five pieces (Pieces 6-12). Principal lithologies within this series include olivine gabbro, troctolite, and gabbronorite, all with equigranular to seriate textures. One characteristic feature of this series is a moderate to strong magmatic foliation defined by the strong alignment of tabular plagioclase and, if present, elongated anhedral olivine. All boundaries between the different lithologies are parallel to the foliation and sutured. When boundaries were recovered, they were always modal, sometimes in combination with slight changes in texture and grain size (Table T2; Fig. F3).

Details of this series are shown in Figure F7. The series starts with Interval 15 , a $5 \mathrm{~cm}$ thick mediumgrained troctolitic olivine gabbro followed by a 25 $\mathrm{cm}$ thick sequence of medium-grained olivine-bearing gabbronorite (Interval 16). The next interval consists of $11 \mathrm{~cm}$ of medium-grained olivine gabbro (Interval 17) followed by a relatively thin layer (2 $\mathrm{cm}$ ) of troctolite (Interval 18) that shows a relatively sharp boundary relative to the neighboring gabbroic layers as well as a slightly larger grain size than other gabbroic rock of the Layered Gabbro Series. Interval 19 is an $11 \mathrm{~cm}$ thick medium-grained olivine-bearing gabbronorite that shows a gradational transition (see next section) to the following Interval 20 , which is a $17 \mathrm{~cm}$ thick layer of medium-grained orthopyroxene-bearing olivine gabbro. The boundary to the next interval, which is a $6 \mathrm{~cm}$ thick layer of mediumgrained olivine-bearing gabbronorite (Interval 21), is relatively sharp. Although all intervals within this series show relatively strong magmatic foliation (see "Structural geology"), the last interval of this series, a gabbronorite (Interval 22), shows markedly weaker magmatic foliation but still with an orientation parallel to the boundaries and subparallel to the modal layering. This last interval consists of three similar pieces without recovered boundaries, so the length of this interval, $33 \mathrm{~cm}$, must be regarded as a minimum thickness.

Analysis of enhanced images from Section 345U1415I-4R-1A highlights the modal variations along the complete Layered Gabbro Series of Intervals 1618. The rock types vary from troctolite, olivine gabbro, and olivine-bearing gabbronorite to troctolitic olivine gabbro (from the bottom of Piece 8 to the top of Piece 6). Estimation of the mineral modes was based on $1 \mathrm{~cm}$ increments parallel to the layering (or 
foliation). The result, presented in Figure F8, shows continuous trends for the individual minerals, with smooth transitions at the boundaries between the different lithologies. The total length of the coherent layered sequence in Hole U1415I is $1.1 \mathrm{~m}$, which comprises $69 \%$ of the recovered core and $15 \%$ of the hole. This is a minimum estimation, as some layered gabbro may not have been recovered.

\section{Details on the relation between oikocrysts and background rock}

Large (up to $15 \mathrm{~mm}$ ) clinopyroxene oikocrysts are unusual in oceanic gabbroic rocks. Moreover, one investigated gabbro also contains $10 \mathrm{~mm}$ sized clinopyroxene oikocrysts. The relationship between the fabric of plagioclase hosted in the matrix and oikocrysts is variable. Plagioclase chadacrysts may be oriented in a random manner within the oikocryst, in accordance with the surrounding randomly oriented plagioclases of the gabbroic matrix (e.g., Thin Section 18; Sample 345-U1415I-3R-4, 16-19 cm [Piece 2]) (Fig. F9). By contrast, in a clinopyroxene oikocryst-bearing troctolite sample (Interval 19; Sample 345-U1415I-4R-2, 8.5-13 cm [Piece 2]) plagioclase chadacrysts show random orientation, whereas plagioclase of the troctolitic matrix define a strong foliation (e.g., Thin Section 19; Sample 345-U1415I-4R-2, 9-13 cm [Piece 2]) (Fig. F9). This implies that the oikocrysts do not correspond to simple poikilitic growth in a later stage of magmatic evolution, which would be expected assuming the standard model of simple fractional crystallization of mid-ocean-ridge basalt (MORB) (e.g. Grove and Bryan 1983; Berndt et al., 2005). In the same thin section, matrix plagioclases as well as the chadacrysts within the oikocrysts show a very strong patchy zonation (Fig. F10). Moreover, some of the plagioclase chadacrysts show plastic deformation (as observed in the troctolitic matrix), whereas the clinopyroxene oikocrysts are virtually undeformed (Fig. F21). All of these observations, together with the absence of olivine as chadacryst, although it is omnipresent in the troctolitic matrix, support a complex model of oikocryst formation that is significantly different from a simple latestage growth in an evolved magma enclosing earlier crystallized minerals.

\section{Significance of magmatic features}

Coring in this hole recovered a number of remarkable textural and mineralogic features that are unusual and highly significant for the formation of the lower ocean crust. In the upper part of the hole, comprising rounded rubble clasts of Unit I, the general relationships are the same as in Holes U1415DU1415H (i.e., lithologies mostly consistent with deri- vation from a wide variety of structural levels with in the lower crust). The Layered Gabbro Series of Unit II penetrated a larger slump block, perhaps more nearly in place, and displays both clinopyroxene oikocrystic gabbro types observed in Hole U1415H, well-developed magmatic layering, and orthopyroxene-bearing olivine gabbro.

Magmatic layering is considered one of the key observational features expected of ocean crust that to date has been rarely directly observed. Many authors have observed microscopic textural evidence of crystal accumulation typical of layered rocks (Engel and Fisher, 1969; Melson and Thompson, 1970; Meyer et al., 1989; Francheteau et al., 1990) that occurs because of a number of processes operating on the scale of a gabbroic magma chamber and is thought of as a ubiquitous feature of the oceanic lower crust. However, actual modal and rhythmic layering implied by the microscopic observations have not been found in any great quantity in any oceanic sampling campaign.

The occurrence of primitive orthopyroxene-bearing mafic magmatic rock from deep fast-spread oceanic crust is also new in Hole U1415I. Normally, orthopyroxene is not common as a phenocryst mineral in MORB and is thought of generally as a very late forming phase in conjunction with significant oxides in the upper part of the gabbroic section in the ocean crust. It is thus quite unusual to find orthopyroxene nearly throughout the rhythmically layered section in Hole U1415I.

\section{Metamorphic petrology}

\section{Background alteration}

Unit I is a surficial rubble unit that contains a variety of discontinuous gabbroic rock (Intervals 1-3) as well as several sections of drilling-induced disaggregated gabbro cuttings (Intervals 4-7). Despite the lithologic variability, the alteration intensity and style within Unit I are similar to alteration observed in the underlying coherent Layered Gabbro Series of Unit II, and for this reason the units are described together (Table T5).

All of the lithologies in Hole U1415I show some degree of hydration, with highly variable extents of alteration. Gabbroic rock exhibits pervasive background alteration and is typically moderately altered (10\%-60\%) but ranges to completely altered (>90\%) locally. Enhanced alteration is associated with cataclastic zones, olivine-rich zones, and regions with a higher density of microcracks, igneous contacts, and hydrothermal veins. Most of the secondary minerals are identifiable in hand specimen; optical petrogra- 
phy was required for the identification of some particularly fine grained minerals.

Although the alteration style, in terms of replacement phases, is consistent across Units I and II, the Layered Gabbro Series of Unit II (Section 345U1415I-4R-1) is somewhat less altered (10\%-30\%) relative to other sections, although alteration intensity is elevated $(40 \%-60 \%)$ in the relatively olivinerich zones. In these olivine-rich zones, serpentinization of olivine results in cracking around the relict olivine grains and surrounding minerals, possibly allowing enhanced fluid flow and alteration along grain margins.

\section{Pyroxene}

Clinopyroxene is moderately to strongly altered (30\%-90\%) to pale green amphibole and possibly chlorite. Slightly altered clinopyroxene has a clear core that grades outward to a corroded rim with amphibole replacement along cleavage surfaces. Brown amphibole was not observed in Hole U1415I, nor was it observed in Holes U1415E, U1415G, and $\mathrm{U} 1415 \mathrm{H}$. Orthopyroxene, where present, is typically strongly altered ( $>90 \%)$ to colorless or pale green amphibole + chlorite \pm talc.

\section{Olivine}

Olivine is partially to totally altered (30\% to $>90 \%$, typically $>90 \%$ ) most commonly to serpentine, showing mesh textures with magnetite \pm clay minerals \pm talc \pm pyrite. Radial cracks commonly extend through chlorite rims into otherwise relatively fresh plagioclase crystals in troctolitic gabbroic rock (Fig. F11A, F11B). These features may result from an increase in volume associated with serpentinization. In some cases, olivine is completely altered to tremolite \pm talc \pm chlorite; pyrite is associated with this assemblage. Corona textures of tremolite and chlorite are commonly present, even in the presence of relatively unaltered pyroxene and plagioclase (Fig. F11C, F11D). Replacement of olivine by talc occurs in some of the most altered rocks recovered from this hole.

\section{Plagioclase}

In most of the rock of Hole U1415I, plagioclase is slightly to moderately altered $(<10 \%-60 \%)$ to assemblages of secondary plagioclase, prehnite, and chlorite. Plagioclase laths included in pyroxene oikocrysts are typically fresh with little evidence of alteration. Plagioclase is commonly altered to chlorite where it is in contact with relict olivine. The apparent volume increase associated with the serpentinization of olivine causes surrounding plagioclase grains to crack, commonly radiating away from oliv- ine and olivine coronas, resulting in enhanced alteration (commonly to prehnite \pm chlorite) along these cracks (Fig. F12). Plagioclase crystals are highly fractured with minor to moderate $(<10 \%-30 \%)$ replacement by secondary plagioclase, prehnite, and in some cases zeolite along fracture surfaces in areas adjacent to zones of cataclasis (see "Structural geology").

\section{Veins}

Veins are mostly thin (1-2 mm), isolated, and dominated by subgreenschist facies minerals including prehnite, zeolite, and clay minerals (possibly smectite). Networks of thin prehnite veins with branched connectivity and irregular shape are common and occur in all lithologies, most often associated with cataclasis and brittle fractures (Figs. F13, F14; see also "Alteration veins"). Very thin $(<1 \mathrm{~mm})$ carbonate veins also occur within Core 345-U1415I-3R. Microscopic prehnite and zeolite veins often crosscut plagioclase crystals and are commonly adjacent to altered olivine (e.g., Fig. F12). Thin amphibole and epidote veins with an average thickness of $<1 \mathrm{~mm}$ also occur in this core, although such veins are less common than the prehnite, zeolite, and clay mineral veins. Veins are irregular in shape and characterized by sharp contacts with the host rock. Networks of thin veins are present in many rocks within this core. Some of the veins are cataclastic and show prehnite replacing pulverized plagioclase. Microfractures, predominantly associated with plagioclase, are filled with fine-grained prehnite. The chronology of veining is difficult to establish because crosscutting relationships are not always apparent; however, a brief approximate chronology is, from oldest to youngest,

- Amphibole \pm epidote and epidote/clinozoisite,

- Chlorite and prehnite \pm serpentine,

- Clay minerals, and

- Zeolite.

\section{Altered cataclasites}

Complete replacement of cataclastic matrix by secondary minerals, most commonly by prehnite but also by zeolite, occurs in several cores (e.g. Samples 345-U1415I-2R-1, 24.5-31.5 cm; 4R-2, 13-17 cm; and $5 \mathrm{G}-1,18-24.5 \mathrm{~cm})$. Comminuted plagioclase is commonly replaced by prehnite and sometimes carbonate in the cataclasite zones. Figures F14C and F15D show a cataclastic texture in Sample 345U1415I-2R-1, 24.5-31.5 cm (Piece 7), in which clinopyroxene is broken along cleavages, forming clasts in a fine-grained dark groundmass presumed to be mainly feldspar. A replacement front can be seen 
where the cataclastic matrix has been completely replaced by medium-grained clear prehnite aggregates with randomly oriented clasts of clinopyroxene or amphibole left unaltered from the earlier cataclastic texture. Veins of prehnite and zeolite \pm carbonate cut both the cataclasite and prehnite replacement, and in a few places in this interval (Interval 3), the medium-grained prehnite is deformed in turn. The finegrained cataclastic plagioclase is likely extremely reactive because of the damaged grains and high surface area. Prehnite textures in the cataclastic samples are different from the fine-grained, dusty prehnite normally seen as pervasive partial replacement or oriented seams along presumed fractures in plagioclase (i.e., Fig. F15).

Sample 345-U1414I-5G-1, 8.5-12.5 cm (Piece 2), composed primarily of prehnite, is inferred to be vein filling from a cataclastic zone (Fig. F16). The identification of prehnite in this vein was confirmed by X-ray diffraction (XRD) analysis. This piece has no visible contacts with gabbroic material and was recovered in a ghost core. This material is interesting because it shows clear evidence of cataclasis and intense alteration over a region at least $5 \mathrm{~cm}$ in width.

\section{Drill cuttings}

In lithologic Unit I, Core 345-U1415I-3R (Intervals 4-7) consists mainly of coarse sand-sized drill cuttings. Three grain mounts from these intervals were point-counted to establish primary and secondary mineralogy (Table T4). Clasts in the grain mounts are highly altered compared to the average recovered core, containing significant amphibole, prehnite, secondary plagioclase, zeolite, chlorite, and clays, including broken corona textures after olivine (Fig. F15B). The clasts also contain cataclasite (12\%-20\%), with prehnite sometimes replacing the matrix (Fig. F15C). Representative samples analyzed by XRD confirm the presence of calcic plagioclase, clinopyroxene, chlorite, and amphibole (Samples 345U1415I-3R-1, 38-43 cm, and 3R-2, 70-76 cm, in Table T6).

Although the reconstructed primary mode of the grain mounts is similar to the typical olivine gabbro in the core (see "Igneous petrology"), the alteration and deformation are as intense as the most altered intervals collected in lithologic Unit II. We conclude that either the cuttings were collected mainly from a fault zone or that unrecovered parts of each section consisted of such rocks. In either case, it is clear that the recovered core is not fully representative of the extent of alteration and cataclastic deformation in Hole U1415I.

\section{Metamorphic conditions and history}

The dominant alteration of the rock recovered in Hole U1415I ranges from lower amphibolite to subgreenschist facies conditions. Compelling evidence for higher temperature alteration, (i.e., dark green or brown amphibole) is absent from these samples, although it is possible that some of the amphibole replacing clinopyroxene and filling microfractures may have formed at middle to upper amphibolite facies.

Coronitic textures (olivine + plagioclase $=$ tremolite + chlorite \pm talc) are variably developed, indicating middle to lower amphibolite facies hydration (Blackman et al., 2011; Nozaka and Fryer, 2011). Primary plagioclase is largely unaltered, except where in contact with relict olivine or where fractured in cataclastic zones. The presence of zeolite veins indicates that hydration occurred at or below those of the zeolite facies.

The alteration asemblages recovered in Hole U1415I record a sequence of cooling during alteration. The corona textures after olivine indicate lower amphibolite facies hydration (Blackman et al., 2011; Nozaka and Fryer, 2011). Serpentininzation of olivine and prehnitization of plagioclase likely occurred at lower temperatures. This was followed by low-temperature cataclasis and prehnite mineralization of cataclasite cements. The presence of brittle deformation of epidote veins implies that cataclasis occurred below the temperatures at which epidote forms $\left(\sim 350^{\circ} \mathrm{C}\right.$; Bird and Spieler, 2004). Finally, crosscutting zeolite veins imply hydration occurred at temperatures of $\sim 100$ $150^{\circ} \mathrm{C}$.

The temporal evolution of metamorphism in Hole U1415I is, from oldest to youngest,

- Development of olivine coronas,

- Serpentinization of olivine and cracking of adjacent plagioclase,

- Formation of amphibole veinlets(?),

- Cataclasis, and

- Formation of low-temperature prehnite and zeolite veins and replacement of cataclastic cement by prehnite and zeolite.

\section{Structural geology Magmatic structures}

The uppermost core sections (345-U1415I-1R-1, 1R2 , and 1R-3) compose a rubble unit with cobbles and five cored pieces of olivine gabbro (upper part of Unit I). All pieces from these three sections are relatively small (11 cm maximum length), and no mag- 
matic layering was recognized (possibly because of the small size of the pieces). Sections $4 \mathrm{R}-1$ and $4 \mathrm{R}-2$ of the Layered Gabbro Series of Unit II recovered 1.6 $\mathrm{m}$ of relatively continuous core, including one $42 \mathrm{~cm}$ long piece (Sample 345-U1415I-4R-1 [Piece 8]) with centimeter- to decimeter-scale layering defined by differences in modal mineralogy and more rarely by grain size (Figs. F17, F18A). Layers are largely defined by variation in modal olivine and, to a lesser extent, pyroxene and have planar boundaries with sharp contacts at $<1 \mathrm{~cm}$ scale. The dip of the layers is consistently between $29^{\circ}$ and $38^{\circ}$ (mean dip $=32^{\circ}$; standard deviation $=7.5^{\circ}$ ). Layering is evident in $32 \%$ (by length) of the recovered core, but this must be regarded as a minimum because layering thicker than piece length is only recognized if contacts are preserved. Boundaries between layers observed in both core pieces and in thin section are parallel to the magmatic foliation. No abrupt intrusive contacts were observed, which is consistent with the interpretation that the layering formed under hypersolidus conditions.

More than $77 \%$ of the recovered core pieces exhibit foliation defined by planar, weak to strong plagioclase, and olivine shape-preferred orientation (SPO) (Fig. F19A). This estimate should also be regarded as a minimum because weak fabrics are hard to recognize in pieces that have also undergone cataclasis, are small, or are coarse grained. All estimates of foliation strength in core pieces were validated by examination of the foliation in thin section, where possible. Foliation intensity seems to increase in strength with increasing olivine content (Fig. F19B). Olivine gabbro, the dominant rock type (see "Igneous petrology"), has weak to moderate foliation (Fig. F19C). Too few pieces of gabbro, gabbronorite, and troctolite were recovered from this hole to allow for meaningful analysis of their characteristic fabric strength. Weak olivine lineation was observed within the plane of the foliation in a few of the olivine gabbro pieces.

Microscopic observations show that magmatic foliation is defined by plagioclase crystals but may also be defined by olivine and, to a lesser extent, orthopyroxene and clinopyroxene when the crystals have suitable habits. In all cases, foliation is defined by both the preferred orientation and the shape anisotropy of the crystals. The plagioclase crystals are commonly tabular and as long as $5 \mathrm{~mm}$ (normally 1-2 $\mathrm{mm}$ in length), with aspect ratios of as much as 8:1. Their [010] albite twin planes typically parallel the long axes of the crystals (Fig. F18C). Olivine crystals are often tabular and 1-3 $\mathrm{mm}$ in length, with aspect ratios as high as 6:1 and [010] olivine axes likely perpendicular to the foliation, and sometimes exhibit distinct skeletal shapes (Donaldson, 1976) (Fig. F18E). Less commonly, orthopyroxene and clinopyroxene crystals (3-5 $\mathrm{mm}$ in length) also exhibit elongation of as much as 4:1 parallel to the foliation (Fig. F18B, F18C). However, in many cases clinopyroxene appears as relatively large $(0.5-2 \mathrm{~cm}$ diameter $)$ subequant oikocrysts around which the plagioclase-defined foliation may be deflected.

Figure F20 shows four examples over the full range of foliation strength observed in the core: isotropic, weak, moderate, and strong (as defined in "Structural geology" in the "Methods" chapter [Gillis et al., 2014e]). Figures F18B and F18C are close-up images of the strong plagioclase, olivine, and clinopyroxene foliation observed in Sample 345-U1415I-4R1A, 35-38 cm (Piece 6). Figure F18 also shows examples of microstructures within Piece 6 that are typical of those seen throughout the Hole U1415I core, including deformation twins in a plagioclase crystal (Fig. F18D), skeletal olivine crystals (Fig. F18E), and subgrain development with straight grain boundaries in olivine (Fig. F18F).

Deflection of magmatic foliation is common around relatively large $(0.5-2.0 \mathrm{~cm})$ pyroxene oikocrysts developed in Sections 345-U1415I-4R-1 and 4R-2. Figure F21 illustrates how a moderate-strength foliation defined by plagioclase and olivine SPO (Fig. F21B) wraps around and between clinopyroxene oikocrysts in troctolite (Sample 345-U1415I-4R-2, 9-13 cm [Piece 2]). No obvious rotation of the oikocryst with respect to the foliation could be discerned. Plagioclase crystals hosted by oikocrysts are typically sparse, show random orientation (i.e., do not show foliation), and are characteristically smaller and more elongate than those outside the oikocryst (Fig. F21A). In this example, rare plagioclase crystals within the oikocrysts are bent (Fig. F21E), suggesting that crystal-plastic deformation occurred above the solidus before the final crystallization of clinopyroxene. Above-solidus crystal-plastic deformation likely explains subgrain development in olivine and deformation twinning in plagioclase away from the oikocryst, as shown in Figure F21C.

Figure F22 highlights representative igneous microstructures seen in samples from Hole U1415I that provide insights into the development of the magmatic foliation. Variations in deformation twinning, bending, and undulose extinction shown by plagioclase crystals away from clinopyroxene oikocrysts are highlighted in Figures F22A and F22B. Figures F22C and F22D show the ubiquitous annealed plagioclase grain boundaries and $120^{\circ}$ grain triple junctions. Figure F22E illustrates plagioclase subgrain development, and Figure F22F shows curious interfingering/ bulging grain boundaries between plagioclase and a 
large clinopyroxene. This texture suggests dissolution and grain boundary migration (Passchier and Trouw, 2005).

The presence of rare to common crystal-plastic deformation in both plagioclase and olivine suggests deformation during crystallization of the crystal mush. Annealed plagioclase grain boundaries, subgrain development, and evidence for grain-boundary migration hints that even more crystal-plastic deformation may have been obscured/removed during near-solidus cooling. The presence of apparently relatively few deformed olivine crystals with a skeletal morphology, however, argues against significant recrystallization (Donaldson, 1976). The observation that the magmatic foliation wraps around the large pyroxene oikocrysts (and crystal-plastic deformation) suggests that some component of compaction was involved during formation of the magmatic foliation. It remains unclear from these rocks alone, however, how the magmatic foliation was formed.

\section{Crystal-plastic deformation}

No significant, structurally continuous subsolidus crystal-plastic deformation was observed in the recovered section, except for one thin $(0.5-1 \mathrm{~cm})$ subvertical zone of protomylonitic deformation along the margin of a prehnite vein in Sample 345-U1415I2R-1, 14.4-35 cm (Pieces 5, 7, and 8).

\section{Cataclastic deformation}

Brittle structures in Hole U1415I are minor and restricted to a few thin zones of cataclasite and ultracataclasite recovered in intervals 345-U1415I-2R-1, 0-57.5 cm (Fig. F23); 4R-1, 0-143 cm; and 4R-2, 0-17 $\mathrm{cm}$ (Fig. F24A), comprising roughly $4 \%-5 \%$ of recovered pieces. Cataclastic deformation in interval 2R-1, 24.5-31.5 cm, shows subvertical orientation (Fig. F23B). Crosscutting relationships indicate a complex succession of vein formation and cataclastic deformation. One sample (Thin Section 13; Sample 345U1415I-2R-1, 25-31 cm [Piece 7]) shows a deformed prehnite vein along with the cataclasite (Fig. F24B). Undeformed prehnite veins also cut cataclasite (Fig. F24C), suggesting repeated fracturing and fluid flow events, at least locally, under low-grade metamorphic conditions.

\section{Alteration veins}

Macroscopic alteration veins were observed during core description. Data on the location, mineralogy, and morphology of veins and associated wall rock alteration were recorded for each vein. Roughly $85 \%$ of the 35 pieces of gabbroic rock recovered from Hole U1415I host alteration veins. Despite being common, alteration vein abundance is variable. In $65 \%$ of the pieces, fewer than a few veins per $10 \mathrm{~cm}$ of recovery were observed. In the remaining $20 \%$, a high number of veins was observed (from 10 veins to significantly $>10$ veins per $10 \mathrm{~cm}$ of recovery). All alteration veins observed in Hole U1415I are very thin, with a maximum thickness is of $0.5 \mathrm{~cm}$; veins thicker than $0.1 \mathrm{~cm}$ are not frequent. Many veins are no more than $0.01 \mathrm{~cm}$ in thickness (thinner features were not recorded as veins), with a mean vein thickness of $0.075 \mathrm{~cm}$ (average $=44$ measurements). Accordingly, alteration veins represent $<1 \%$ of the volume of the cores. Vein length typically exceeds the core width $(6 \mathrm{~cm})$, although vein terminations (vein tips) are frequently observed. Short, thin veins may branch to longer and thicker ones. Contact relations with host gabbroic rock ranges from diffuse to clear. No well-developed alteration halos were observed (macroscopically).

No systematic correlation between the mineralogy of the vein-filling material and the vein abundance or thickness was observed, although the prehnite veins are definitely the most common and often cut other vein types (see below). Prehnite vein shape is typically irregular but commonly curved, and locally veins form anastomosing networks. En echelon and overlapping veins dominate in the largest pieces. Apparent crosscutting relationships were frequently observed, but clear, measurable offsets are infrequent, and where observed, determining if these are real offsets or veins branching from each other is difficult.

A hierarchy of crosscutting relationships based on vein mineralogy has not been established for Hole U1415I (barring a single example of one albite vein crosscut by a prehnite vein), implying such a hierarchy likely does not exist at this location. Longer pieces show two vein orientations: (1) a shallow-dipping vein population subparallel to the igneous layering, although still cutting the primary igneous fabric at a low angle, and (2) a vein population emplaced at a high angle relative to the igneous layering. However, other veins in smaller pieces have intermediate dips. Globally, vein orientations can be described as random. However, because of the limited number of measured veins in this hole (19), this conclusion is not statistically robust.

Microscopic observations illustrate the two populations. Examples include irregular fractures hosting chlorite veins roughly orthogonal to magmatic foliation (Thin Section 22; Sample 345-U1415I-4R-1, 48$50 \mathrm{~cm}$ [Piece 8A]) and a second example showing minor curved to irregular veins subparallel to the magmatic layering (Thin Section 12; Sample 2R-1, 2-6 $\mathrm{cm}$ [Piece 1]). 


\section{Temporal evolution}

Temporal evolution of structures recovered in Hole $\mathrm{U} 1415 \mathrm{H}$ is, from oldest to youngest,

- Intrusion of gabbroic rock,

- Formation of magmatic fabric (layering and foliation),

- Limited crystal-plastic deformation in the mush and annealing of plagioclase,

- Localized cataclasis associated with low-temperature faulting and low-temperature vein formation,

- Vein formation, and

- Open fractures.

\section{Paleomagnetism}

The primary goal of paleomagnetism studies is to quantify the structure, direction, and intensity of natural remanent magnetization (NRM) in the different rock types that make up the lower oceanic crust and to use these data to provide insights into the crustal accretion, deformation, and source of marine magnetic anomalies. In addition, magnetic fabric analysis can provide valuable information on the degree and direction of weakly preferred alignments of mineral phases, leading to improved understanding of magmatic and tectonic processes.

\section{Remanence data}

\section{Continuous measurements}

A range of gabbroic and troctolitic lithologies were sampled during Expedition 345, and recovery was sufficient to allow first-order characterization of magnetic remanences using the pass-through superconducting rock magnetometer (SRM) and in-line alternating field (AF) demagnetizer. Remanence measurements were made at $2 \mathrm{~cm}$ intervals on all archive-half core pieces longer than $\sim 9 \mathrm{~cm}$. All archive-half cores were subjected to stepwise AF demagnetization at $5 \mathrm{mT}$ steps up to maximum peak fields of $80 \mathrm{mT}$. Remanence data and corresponding archive-half core point magnetic susceptibility data were filtered to preserve only data corresponding to the intervals where remanence measurements were made and to discard data obtained within $4.5 \mathrm{~cm}$ of piece ends. Thus, the resulting remanence and susceptibility data sets are significantly less affected by artifacts resulting from small core pieces than the original unfiltered data sets.

For the purpose of characterization based on bulk magnetic parameters at Site U1415, lithologies are divided into Group 1, gabbroic rock, and Group 2, troctolitic rock. Only one archive-half core section
(345-U1415I-4R-1A) and one other individual core piece (Sample 345-U1415I-2R-1 [Piece 11]) from Hole U1415I were suitable for measuring using the SRM system. Group 1 lithologies in these samples include olivine gabbro, orthopyroxene-bearing olivine gabbro, gabbronorite, and olivine-bearing gabbronorite, with a geometric mean NRM intensity of $360 \mathrm{~mA} / \mathrm{m}$ (range $=72 \mathrm{~mA} / \mathrm{m}$ to $\mathrm{S} 1.23 \mathrm{~A} / \mathrm{m} ; n=24$ ) (Fig. F25). Only a narrow layer of troctolite in the center of Section 345-U1415I-4R-1A falls into Group 2, with a geometric mean NRM intensity of $1.37 \mathrm{~A} / \mathrm{m}(n=2)$. The geometric mean magnetic susceptibilities of Group 1 and 2 samples are $174 \times 10^{-5}$ and $2051 \times 10^{-}$ ${ }^{5} \mathrm{SI}$, respectively.

The variation in magnetic susceptibility, NRM intensity, and modal percentage of olivine through Section 345-U1415I-4R-1A is illustrated in Figure F25. The highest magnetic susceptibilities and NRM intensities in this section correspond to a $5 \mathrm{~cm}$ wide interval of troctolite in the center of the section, but a clear link also exists between magnetic susceptibility and original olivine content throughout the section. Note that the broad peak in NRM intensities across the troctolite interval results from the broad response function of the SRM superconducting quantum interference device sensors, which have a full width of $\sim 10 \mathrm{~cm}$ at half-peak amplitude. Magnetic susceptibility and NRM intensity are parameters that are predominantly controlled by the concentration of magnetite (in rocks with magnetite concentrations $>0.01 \mathrm{wt} \%$; Tarling, 1983), and olivine is paramagnetic (i.e., nonremanence carrying) when pure. Hence, this suggests that the magnetic properties of these rocks are significantly influenced by variable degrees of serpentinization/alteration of the more olivine-rich lithologies through the production of secondary magnetite from these processes.

Remanent magnetization directions were calculated by principal component analysis (PCA; Kirschvink, 1980) at all measurement points where linear components could be identified on orthogonal vector plots of demagnetization data. Figure F26 shows representative examples of AF demagnetization behavior. Sample 345-U1415I-2R-1A, $52 \mathrm{~cm}$, exhibits demagnetization behavior that is unique among the samples measured in Hole U1415I (Fig. F26A). After removal of a very minor drilling-induced magnetization during initial demagnetization, this sample is characterized by a single, high-coercivity component with a negative inclination that decays smoothly toward the origin of the orthogonal vector plot. All other samples (Fig. F26B-F26E) have an initially downward directed remanence, with evidence of inclination steepening caused by acquisition of a drill- 
ing-induced magnetization (DIRM) that is at least partially removed by low-field treatments $(<15 \mathrm{mT})$. This is followed by removal of a moderately inclined, downward-directed component, typically by fields of 25-30 mT (Fig. F26A). At demagnetization fields $>30$ $\mathrm{mT}$, remanence directions migrate back to the lower hemisphere, and magnetization intensities increase continuously up to the peak applied field of $80 \mathrm{mT}$ (see expanded portions of the orthogonal vector plots in Fig. F26B-F26E). This increase is due to acquisition of spurious, laboratory-imparted, anhysteretic remanent magnetizations (ARMs) along the $z$ axis of the SRM system, which has been a characteristic problem of this system observed on several IODP expeditions (e.g., Expedition 335 Scientists, 2012). ARM acquisition appears to relate to passage of archive-half core sections through a significant residual direct magnetic field as they exit the demagnetizing coils in the SRM. Unfortunately, the development of these anomalous ARMs in archive-half core samples prevents isolation of sufficient high-coercivity components in these rock pieces to allow geological interpretation.

The downward-directed, low- to moderate-coercivity component present between DIRM and ARM components in these samples is consistently very linear (with maximum angular deviations of $1^{\circ}-3^{\circ}$ when picked over at least four demagnetization steps). The mean inclination of this component is $49.9^{\circ}(k=$ $\left.28.2 ; \alpha_{95}=6.8^{\circ} ; n=17\right)$, calculated using the Arason and Levi (2010) maximum likelihood method. The origin of these components is discussed fully in "Paleomagnetism" in the "Hole U1415J" chapter (Gillis et al., 2014d), in which more extensive data are used to demonstrate that this downward-directed remanence is related to the drilling-induced magnetization in these cores.

\section{Discrete samples}

As a result of low recovery of oriented core pieces in Hole U1415I, shipboard experiments on discrete samples were limited to only three minicube samples cut from Sections 345-U1415I-2R-1W and 4R-1W. These samples consist of orthopyroxene-bearing olivine gabbro, gabbronorite, and olivine-bearing gabbronorite and provide some insights into variations in demagnetization characteristics. Orthogonal vector plots of demagnetization data from these samples are presented in Figure F27. Sample 345-U1415I-2R$1 \mathrm{~W}, 52 \mathrm{~cm}$ (orthopyroxene-bearing olivine gabbro) is dominated by a clear, single component of high coercivity (Fig. F27A) with an inclination of $-47.0^{\circ}$. Unfortunately, the remaining two discrete samples from Hole U1415I display complex and erratic demagnetization behavior, with no linear paths suit- able for PCA. With only one of three discrete samples yielding usable AF demagnetization data, we decided to focus predominantly on thermal demagnetization of discrete samples from subsequent holes, as this technique has yielded high-quality data in gabbroic rock recovered during other IODP expeditions (e.g., Morris et al., 2009).

\section{Geological interpretation of remanence data}

Remanence data from Hole U1415I are too limited to allow geological interpretation in terms of the magnetic polarity of the sampled section or its tectonic rotation history. $\mathrm{U}-\mathrm{Pb}$ dating of zircon from samples collected in the immediate vicinity of Site U1415 during the JC21 site survey cruise yielded ages of 1.42-1.27 Ma (Rioux et al., 2012). These dates lie in the middle of reversed polarity Chron C1R (Cande and Kent, 1995), suggesting that any primary magnetizations preserved in the sampled rocks should be of reversed polarity. However, the expected direction of magnetization at Hess Deep based on the geocentric axial dipole field at the site has a declination of $000^{\circ}$ and an inclination of $4.7^{\circ}$ for a normal polarity field and a declination of $180^{\circ}$ and an inclination of $-4.7^{\circ}$ for a reversed polarity field. Hence, the polarity of these rocks cannot be determined uniquely in the absence of reoriented core samples. Regardless of polarity, the inclinations of the single reliable discrete sample (inclination $=-47^{\circ}$ ) and single reliable archive-half core sample (inclination $=-27^{\circ}$ ) imply significant tilting of the section after remanence acquisition, although clearly little confidence can be placed on such limited data.

\section{Magnetic fabric}

Anisotropy of magnetic susceptibility (AMS) determined for three discrete samples from Hole U1415I is illustrated on the equal-area stereographic projections of Figure F28. Susceptibility tensors are weakly to moderately anisotropic (corrected anisotropy degree $\left[P^{\prime}\right]<1.34$ [mean $\left.=1.11\right]$ ) (Jelinek, 1981). All three ellipsoid shapes (triaxial, oblate, and prolate) are represented in these discrete samples. Average bulk susceptibilities suggest that the AMS signal is dominated by magnetite in these samples rather than contributions from other paramagnetic minerals. Magmatic foliations in two samples were sufficiently well-developed to be measured in the core reference frame, and these structural measurements show different relationships to the AMS fabrics. In one sample, AMS magnetic foliation is nearly parallel to the magmatic foliation (with $k_{\min }$ corresponding to the pole of the magmatic foliation; Fig. F28A), whereas there is poor agreement with the structural fabric in the other sample (Fig. F28B). 


\section{Inorganic geochemistry}

Geochemistry analysis was completed on three gabbroic rock pieces (one clinopyroxene oikocryst-bearing troctolite, one orthopyroxene-bearing olivine gabbro, and one olivine-bearing gabbronorite) and three sand cuttings from drilling-induced disaggregated gabbro from lithologic Units I and II in Hole U1415I. Sample selection criteria were established during discussion among representatives from all expertise groups within the shipboard scientific party. Major and trace elements were determined by inductively coupled plasma-atomic emission spectroscopy (ICP-AES), and gas chromatography was used for $\mathrm{S}$, $\mathrm{H}_{2} \mathrm{O}$, and $\mathrm{CO}_{2}$ quantifications. Results are reported in Table T1 in the "Geochemistry summary" chapter (Gillis et al., 2014c), and selected data are shown in Figures F29 and F30. Major and trace elements are reported on a volatile-free basis.

\section{Gabbroic rock}

Hole U1415I gabbroic rock has loss on ignition (LOI) values ranging from $1.0-1.6 \mathrm{wt} \%$ for mildly altered gabbro in the lower part of the borehole (Intervals 16 and 22) to $3.2 \mathrm{wt} \%$ in the most altered sample (345U1415I-2R-1, 0-4 cm). Measured LOI appears directly correlated to the water content of the analyzed samples (e.g., $\sim 1 \mathrm{wt}^{2} \mathrm{H}_{2} \mathrm{O}$ in Sample 345-U1415I$4 \mathrm{R}-1,50-52 \mathrm{~cm}$ ) (Fig. F29). These values are consistent with the degree of alteration estimated from thin section descriptions (see "Metamorphic petrology"). Hole U1415I gabbro has low $\mathrm{CO}_{2}$ contents $(<0.1 \mathrm{wt} \%)$ and variable $\mathrm{S}$ compositions (290-560 ppm). No systematic variations of the volatile elements with the mineral mode and/or analyzed elements were observed.

Hole U1415I gabbroic rock has orthopyroxene contents ranging from 0 to $8 \mathrm{vol} \%$ (see "Igneous petrology" and thin section descriptions in "Core descriptions"). The occurrence of orthopyroxene in oceanic gabbro successions is commonly interpreted as indication of crystallization within an evolved system (Shipboard Scientific Party, 1993). In contrast to the variability in modal orthopyroxene contents, Hole U1415I gabbroic rock displays a very restricted range of values for major element compositions (Fig. F30). The studied plutonic rock has primitive compositions with high $\mathrm{Mg \#}(81-82)$ and low $\mathrm{Fe}_{2} \mathrm{O}_{3}$ (4.9-5.8 wt $\%)$ and $\mathrm{SiO}_{2}$ (47.7-49.5 wt\%) contents and display some minor variations in $\mathrm{CaO}$ and $\mathrm{Al}_{2} \mathrm{O}_{3}$ that can be related to variations in the plagioclase/clinopyroxene ratio in the primary mineral assemblage, with $\mathrm{Al}_{2} \mathrm{O}_{3}$ mainly concentrated in plagioclase and $\mathrm{CaO}$ dominant in clinopyroxene in plagioclase-poor samples. Hole U1415I gabbroic rock has relatively high and variable $\mathrm{Cr}$ (700-1110 ppm) and $\mathrm{Ni}(150-300$ ppm) contents and low $\mathrm{TiO}_{2}(0.16-0.18 \mathrm{wt} \%)$ concentrations. Together with their high Mg\#, these compositions suggest crystallization from primitive magmas for Hole U1415I gabbroic rock, the geochemistry of which is similar to that of the gabbronorite sampled in Hole U1415H (Fig. F30).

\section{Drilling-induced disaggregated gabbros}

The three samples of drilling-induced disaggregated gabbro have homogeneous volatile contents, with LOIs ranging from 3.5 to $3.7 \mathrm{wt} \%, \mathrm{H}_{2} \mathrm{O}$ contents ranging from 2.8 to $3 \mathrm{wt} \%$, and $\mathrm{CO}_{2}$ contents of $\sim 0.05 \mathrm{wt} \%$ (Fig. F29). These values are consistent with the abundance of altered minerals observed in the sampled material (see thin section descriptions in "Core descriptions" and "Metamorphic petrology"). These volatile contents are similar to those of the overlying orthopyroxene-bearing olivine gabbro Sample 345-U1415I-2R-1, 0-4 cm (e.g., LOI = 3.2 $\mathrm{wt} \%)$. The similarity in volatiles between this sample and the drilling-induced disaggregated gabbro points toward a similar alteration history for the plutonic rock sampled above $27.5 \mathrm{mbsf}$ in rubble Unit I (see "Igneous petrology").

The drilling-induced disaggregated gabbro has low $\mathrm{Mg \#} \mathrm{(79)}$ and high $\mathrm{TiO}_{2}(\sim 0.4 \mathrm{wt} \%)$ and incompatible lithophile element contents (e.g., Y $=10 \mathrm{ppm}$ ) compared to neighboring gabbro, suggesting that it comprises fractions of more evolved gabbroic material. The gabbro is also distinguished by higher $\mathrm{Na}_{2} \mathrm{O}$ (2.5-2.6 wt\%) and $\mathrm{Sr}(\sim 100 \mathrm{ppm})$ relative to Hole U1415I gabbros $\left(\mathrm{Na}_{2} \mathrm{O}=\sim 1.6-1.9 \mathrm{wt} \%\right.$; $\mathrm{Sr}=\sim 70$ ppm). These values are consistent with the high degrees of alteration of the drilling-induced disaggregated gabbro, which is characterized by, for instance, the abundance of secondary plagioclase (see "Metamorphic petrology" and thin section descriptions in "Core descriptions"). However, the results for the drilling-induced disaggregated gabbro probably also reflect contamination of the sampled material by drilling mud mixed with seawater. Our data provide further evidence of this contamination during drilling. The drilling-induced disaggregated gabbro has high V (140 ppm) and Zn (140-160 ppm) compared to neighboring gabbro $(\mathrm{V}=\sim 40 \mathrm{ppm} ; \mathrm{Zn}=\sim 30$ ppm). These elements are enriched in the antirust coatings used on drilling equipment (Zn) and in the drill bit components ( $V$ in tungsten carbide), and the high $\mathrm{V}$ and $\mathrm{Zn}$ values suggest a non-negligible contamination by drilling materials during downhole disaggregation of the sampled plutonic rocks (Fig. F30E). Because the extent of this chemical contamination cannot be deduced from our data set, the composition of the two disaggregated gabbro sam- 
ples was not used for petrogenetic interpretation of the Hole U1415I plutonic series.

\section{Physical properties}

Physical properties of gabbroic rock recovered in Hole U1415I were characterized through a series of measurements on whole-core sections, half-core sections, half-core pieces, and discrete samples as described in "Physical properties" in the "Methods" chapter (Gillis et al., 2014e). We measured gamma ray attenuation (GRA) density and magnetic susceptibility on the Whole-Round Multisensor Logger (WRMSL); natural gamma radiation (NGR) on the Natural Gamma Ray Logger (NGRL); point magnetic susceptibility, reflectance spectrophotometry, and colorimetry on the Section Half Multisensor Logger (SHMSL); and thermal conductivity, compressional wave velocity, density, and porosity on discrete samples. The rock names reported in data tables correspond to the primary lithologies assigned by the igneous group. Data are summarized as a function of depth in Figure F31.

Raw GRA density, magnetic susceptibility, reflectance spectrophotometry, and colorimetry data were uploaded to the Laboratory Information Management System database and subsequently filtered following the procedures described in "Physical properties" in the "Methods" chapter (Gillis et al., 2014e) to remove spurious points that correspond to empty intervals in the liner, broken pieces, and pieces that were too small. Both raw and filtered data are provided in PHYSPROP in "Supplementary material."

\section{Multisensor core logger data}

\section{Natural gamma radiation}

Only two sections (345-U1415I-2R-1 and 4R-1) were measured on the NGRL; other sections contained pieces too small to provide reliable data with this instrument. NGR is overall very low $(0-0.4 \mathrm{cps})$ in this core, significantly lower than background level $(\sim 5$ cps).

\section{Gamma ray attenuation density}

Two cores (345-U1415I-2R and 4R) were measured on the WRMSL. GRA density measurements are volume dependent and range between $\sim 2.2$ and 2.6 $\mathrm{g} / \mathrm{cm}^{3}$, which is $\sim 0.4 \mathrm{~g} / \mathrm{cm}^{3}$ lower than bulk density measured on discrete samples in the same cores (Fig. F31).

\section{Magnetic susceptibility}

Magnetic susceptibility was measured on both the WRMSL and SHMSL. The whole-round core measure- ments are volume measurements that give an average apparent susceptibility value over an $8 \mathrm{~cm}$ long interval, whereas the SHMSL values are given by point measurements. When measured on wholeround cores, magnetic susceptibility is generally underestimated, with values significantly lower than the point magnetic susceptibility (Fig. F31). The mean magnetic susceptibility of rock recovered in Hole U1415I is very low $\left(311 \times 10^{-5} \pm 544 \times 10^{-5} \mathrm{SI}\right.$ for point magnetic susceptibility; maximum recorded is $3600 \times 10^{-5} \mathrm{SI}$ ), reflecting the absence of magmatic Fe-Ti oxides. The highest measured values correspond to intervals with a higher abundance of magnetite associated with serpentinized olivine (Section 345-U1415I-4R-1; 27.7 mbsf).

\section{Reflectance spectrophotometry and colorimetry}

Reflectance spectrophotometry and colorimetry data, together with point magnetic susceptibility data, were systematically acquired using the SHMSL, with a step size of $2 \mathrm{~cm}$. No significant variation is evident in the recorded reflectance and chromaticity parameters $\left(\mathrm{L}^{*}, \mathrm{a}^{*}\right.$, and $\left.\mathrm{b}^{*}\right)$ along the cores recovered in Hole U1415I. $\mathrm{L}^{*}, \mathrm{a}^{*}$, and $\mathrm{b}^{*}$ mean values are $44.8 \pm$ $6.6,1.19 \pm 0.75$, and $-6.73 \pm 2.39$, respectively.

In an attempt to better detect variations related to mineral composition of the recovered rocks, we conducted a series of measurements with a measurement interval of $1 \mathrm{~mm}$ on Pieces 8, 9, and 10 of Section 345-U1415I-4R-1, which is layered gabbronorite with significant variations in olivine content. The values returned by the instrument were substantially different from those measured previously with a 2 $\mathrm{cm}$ measurement interval. We then made several series of measurements with varying intervals ( 1 and 5 $\mathrm{mm}$ and $5 \mathrm{~cm}$ ), the results of which are presented in Figure F32.

The instrument was calibrated immediately before the first run with $1 \mathrm{~mm}$ measurement intervals. The $a^{*}$ and $b^{*}$ values drifted away from the first measurements (note the different slope for the first $1 \mathrm{~mm}$ interval curves in Fig. F32A, F32B), and the results obtained for each measurement series were different (note the offsets between the first 1 and $5 \mathrm{~mm}$ and 1 $\mathrm{cm}$ curves in Fig. F32A, F32B). In contrast, the $\mathrm{L}^{*}$ values appeared to be stable over the different series of measurements (Fig. F32C). After running a series of tests with color standards, we established that the measured chromaticity values $a^{*}$ and $b^{*}$ oscillated over time in an unpredictable manner (see "Physical properties" in the "Methods" chapter [Gillis et al., 2014e]). This behavior appeared to be related to the sensitivity of the spectrophotometer to temperature changes. After this problem was fixed by the techni- 
cal staff, we remeasured the same core pieces with measurement intervals of $1 \mathrm{~mm}$ and $1 \mathrm{~cm}$. Comparison of these more reliable data with the core (interval 345-U1415I-4R-1, 45-125 cm; Fig. F32) shows that there is no obvious systematic variation of the reflectance parameters with the olivine content of the rock. This may be related to the relatively coarse grains (as large as several millimeters in interval 345U1415I-4R-1, 45-125 cm) or the sensor (7 mm diameter) measuring individual or a few grains rather than a representative aggregate.

\section{Discrete sample measurements}

\section{Moisture and density}

Bulk density, grain density, and porosity were calculated from wet masses, dry masses, and volume following the procedure described in "Physical properties" in the "Methods" chapter (Gillis et al., 2014e) measured on three cubic $(2 \mathrm{~cm} \times 2 \mathrm{~cm} \times 2 \mathrm{~cm})$ samples taken from the working halves of Sections 345U1415-2R-1 and 4R-1 (Table T7; Fig. F31). Average bulk density and grain density are $2.88 \pm 0.06$ and $2.90 \pm 0.06 \mathrm{~g} / \mathrm{cm}^{3}$, respectively, and are similar to densities measured at Hess Deep (Ocean Drilling Program [ODP] Leg 147 Site 894) (Fig. F33). Porosity is low, $\sim 1 \%$ on average.

\section{$P$-wave velocity}

The same three cubic samples used for moisture and density analyses were measured for $P$-wave velocities $\left(V_{\mathrm{p}}\right)$ along the three principal directions $(x, y$, and $z)$ in the core reference frame (see Fig. F2 in the "Methods" chapter [Gillis et al., 2014e]). Results are listed in Table T7 and plotted in Figure F31. Average $V_{\mathrm{P}}$ is $6.32 \pm 0.22 \mathrm{~km} / \mathrm{s}$, and the apparent anisotropy varies from $2 \%$ to $4.3 \%$. We performed two successive series of measurements ( $\geq 10$ in each direction) for each of these three samples, and the results varied by as much as $0.22 \mathrm{~km} / \mathrm{s}(\sim 3.4 \%)$ in a given direction from one series of measurements to another. The related standard deviation of the measured $V_{\mathrm{P}}$ is as much as $1.74 \%$, and the fastest direction changed from $y$ to $x$ for Sample 345-U1415I-4R-1W, 50-52 cm (Piece 8A). Measured apparent anisotropies are low and should therefore be treated with caution; values on the order of $2 \%$ are unlikely to be significant. For the remainder of the expedition, only one series of measurements was performed on each sample. However, the measured velocities are probably not as accurate as suggested by the low standard deviations (typically $<0.1 \%$ ) for each individual measurement series. We consider that the error associated with our measurements is on the order of $2 \%$.
Results are compared in Figure F33 with $V_{\mathrm{P}}$ and grain density measurements made during previous ODP legs and IODP expeditions on gabbroic samples from fast-spreading and slow-spreading oceanic crust. $V_{\mathrm{P}}$ values are consistent with measurements made at Hess Deep (Site 894). Figure F33 shows a large overall dispersion of $V_{\mathrm{p}}$ values. For example, the average value for ODP Leg 118 Hole 735B (Southwest Indian Ridge) is $\sim 1 \mathrm{~km} / \mathrm{s}$ higher than that for IODP Expedition 304/305 Site U1309 (Mid-Atlantic Ridge). We interpret this dispersion as being primarily caused by differences in the measurement protocols and in the performance of the measuring devices used during these different legs/expeditions. No obvious geologically meaningful explanation can be discerned for such large differences in $V_{\mathrm{P}}$ from one site to another with very similar lithologies, porosities, and degrees of alteration. This illustrates the intrinsic limitation of the quality of $V_{\mathrm{P}}$ measurements made on board, and any interpretation using these data should be treated with caution. As expected, the measured $V_{\mathrm{P}}$ at room pressure depends primarily on porosity, which is a reasonable proxy for sample groundmass petrophysical variability (e.g., background alteration) as we avoided taking discrete samples with metamorphic or alteration veins, rather than on lithology.

\section{Thermal conductivity}

Thermal conductivities were measured in three gabbroic rock samples taken at irregularly spaced intervals in Hole U1415I (Table T8; Fig. F31). Measured values range from 2.16 to $2.51 \mathrm{~W} /(\mathrm{m} \cdot \mathrm{K})$ and are averages of 10-20 measurements for each piece, with a standard deviation of $<1.2 \%$. We attempted to measure anisotropy in a foliated orthopyroxene-bearing olivine gabbro (Section 345-U1415I-4R-1A [Piece 9]) by using the shorter probe (see "Physical properties" in the "Methods" chapter (Gillis et al., 2014e), collecting two series of measurements with the probe needle aligned parallel and perpendicular to the foliation. The obtained apparent anisotropy is very weak $(0.3 \%)$, lower than the measurement error; therefore, the anisotropy results are not meaningful. The small probe tends to return less stable values than the large probe, which makes the exercise of estimating the anisotropy of thermal conductivity difficult in this type of lithology.

\section{References}

Arason, P., and Levi, S., 2010. Maximum likelihood solution for inclination-only data in paleomagnetism. Geo- 
phys. J. Int., 182(2):753-771. doi:10.1111/j.1365246X.2010.04671.X

Berndt, J., Koepke, J., and Holtz, F., 2005. An experimental investigation on the influence of water and oxygen fugacity on differentiation of MORB at $200 \mathrm{MPa}$. J. Petrol., 46(1):135-167. doi:10.1093/petrology/egh066

Bird, D.K., and Spieler, A.R., 2004. Epidote in geothermal systems. Rev. Mineral. Geochem., 56(1):235-300. doi:10.2138/gsrmg.56.1.235

Blackman, D.K., Ildefonse, B., John, B.E., Ohara, Y., Miller, D.J., Abe, N., Abratis, M., Andal, E.S., Andreani, M., Awaji, S., Beard, J.S., Brunelli, D., Charney, A.B., Christie, D.M., Collins, J., Delacour, A.G., Delius, H., Drouin, M., Einaudi, F., Escartín, J., Frost, B.R., Früh-Green, G., Fryer, P.B., Gee, J.S., Godard, M., Grimes, C.B., Halfpenny, A., Hansen, H.-E., Harris, A.C., Hayman, N.W., Hellebrand, E., Hirose, T., Hirth, J.G., Ishimaru, S., Johnson, K.T.M., Karner, G.D., Linek, M., MacLeod, C.J., Maeda, J., Mason, O.U., McCaig, A.M., Michibayashi, K., Morris, A., Nakagawa, T., Nozaka, T., Rosner, M., Searle, R.C., Suhr, G., Tominaga, M., von der Handt, A., Yamasaki, T., and Zhao, X., 2011. Drilling constraints on lithospheric accretion and evolution at Atlantis Massif, Mid-Atlantic Ridge $30^{\circ}$ N. J. Geophys. Res.: Solid Earth, 116(B7):B07103. doi:10.1029/2010JB007931

Cande, S.C., and Kent, D.V., 1995. Revised calibration of the geomagnetic polarity timescale for the Late Cretaceous and Cenozoic. J. Geophys. Res.: Solid Earth, 100(B4):6093-6095. doi:10.1029/94JB03098

Cannat, M., Karson, J.A., Miller, D.J., et al., 1995. Proc. ODP, Init. Repts., 153: College Station, TX (Ocean Drilling Program). doi:10.2973/odp.proc.ir.153.1995

Donaldson, C.H., 1976. An experimental investigation of olivine morphology. Contrib. Mineral. Petrol., 57(2):187213. doi:10.1007/BF00405225

Engel, C.G., and Fisher, R.L., 1969. Lherzolite, anorthosite, gabbro, and basalt dredged from the Mid-Indian Ocean Ridge. Science, 166(3909):1136-1141. doi:10.1126/science.166.3909.1136

Expedition 304/305 Scientists, 2006. Expedition 304/305 summary. In Blackman, D.K., Ildefonse, B., John, B.E., Ohara, Y., Miller, D.J., MacLeod, C.J., and the Expedition 304/305 Scientists, Proc. IODP, 304/305: College Station, TX (Integrated Ocean Drilling Program Management International, Inc.). doi:10.2204/ iodp.proc.304305.101.2006

Expedition 335 Scientists, 2012. Expedition 335 summary. In Teagle, D.A.H., Ildefonse, B., Blum, P., and the Expedition 335 Scientists, Proc. IODP, 335: Tokyo (Integrated Ocean Drilling Program Management International, Inc.). doi:10.2204/iodp.proc.335.101.2012

Francheteau, J., Armijo, R., Cheminée, J.L., Hekinian, R., Lonsdale, P., and Blum, N., 1990. 1 Ma East Pacific Rise oceanic crust and uppermost mantle exposed by rifting in Hess Deep (equatorial Pacific Ocean). Earth Planet. Sci. Lett., 101:281(2-4)-295. doi:10.1016/0012821X(90)90160-Y

Gillis, K.M., Snow, J.E., Klaus, A., Guerin, G., Abe, N., Akizawa, N., Ceuleneer, G., Cheadle, M.J., Adrião, Á.,
Faak, K., Falloon, T.J., Friedman, S.A., Godard, M.M., Harigane, Y., Horst, A.J., Hoshide, T., Ildefonse, B., Jean, M.M., John, B.E., Koepke, J.H., Machi, S., Maeda, J., Marks, N.E., McCaig, A.M., Meyer, R., Morris, A., Nozaka, T., Python, M., Saha, A., and Wintsch, R.P., 2014a. Bench site survey. In Gillis, K.M., Snow, J.E., Klaus, A., and the Expedition 345 Scientists, Proc. IODP, 345: College Station, TX (Integrated Ocean Drilling Program). doi:10.2204/iodp.proc.345.103.2014

Gillis, K.M., Snow, J.E., Klaus, A., Guerin, G., Abe, N., Akizawa, N., Ceuleneer, G., Cheadle, M.J., Adrião, Á., Faak, K., Falloon, T.J., Friedman, S.A., Godard, M.M., Harigane, Y., Horst, A.J., Hoshide, T., Ildefonse, B., Jean, M.M., John, B.E., Koepke, J.H., Machi, S., Maeda, J., Marks, N.E., McCaig, A.M., Meyer, R., Morris, A., Nozaka, T., Python, M., Saha, A., and Wintsch, R.P., 2014b. Expedition 345 summary. In Gillis, K.M., Snow, J.E., Klaus, A., and the Expedition 345 Scientists, Proc. IODP, 345: College Station, TX (Integrated Ocean Drilling Program). doi:10.2204/iodp.proc.345.101.2014

Gillis, K.M., Snow, J.E., Klaus, A., Guerin, G., Abe, N., Akizawa, N., Ceuleneer, G., Cheadle, M.J., Adrião, Á., Faak, K., Falloon, T.J., Friedman, S.A., Godard, M.M., Harigane, Y., Horst, A.J., Hoshide, T., Ildefonse, B., Jean, M.M., John, B.E., Koepke, J.H., Machi, S., Maeda, J., Marks, N.E., McCaig, A.M., Meyer, R., Morris, A., Nozaka, T., Python, M., Saha, A., and Wintsch, R.P., 2014c. Geochemistry summary. In Gillis, K.M., Snow, J.E., Klaus, A., and the Expedition 345 Scientists, Proc. IODP, 345: College Station, TX (Integrated Ocean Drilling Program). doi:10.2204/iodp.proc.345.114.2014

Gillis, K.M., Snow, J.E., Klaus, A., Guerin, G., Abe, N., Akizawa, N., Ceuleneer, G., Cheadle, M.J., Adrião, Á., Faak, K., Falloon, T.J., Friedman, S.A., Godard, M.M., Harigane, Y., Horst, A.J., Hoshide, T., Ildefonse, B., Jean, M.M., John, B.E., Koepke, J.H., Machi, S., Maeda, J., Marks, N.E., McCaig, A.M., Meyer, R., Morris, A., Nozaka, T., Python, M., Saha, A., and Wintsch, R.P., 2014d. Hole U1415J. In Gillis, K.M., Snow, J.E., Klaus, A., and the Expedition 345 Scientists, Proc. IODP, 345: College Station, TX (Integrated Ocean Drilling Program). doi:10.2204/iodp.proc.345.110.2014

Gillis, K.M., Snow, J.E., Klaus, A., Guerin, G., Abe, N., Akizawa, N., Ceuleneer, G., Cheadle, M.J., Adrião, Á., Faak, K., Falloon, T.J., Friedman, S.A., Godard, M.M., Harigane, Y., Horst, A.J., Hoshide, T., Ildefonse, B., Jean, M.M., John, B.E., Koepke, J.H., Machi, S., Maeda, J., Marks, N.E., McCaig, A.M., Meyer, R., Morris, A., Nozaka, T., Python, M., Saha, A., and Wintsch, R.P., 2014e. Methods. In Gillis, K.M., Snow, J.E., Klaus, A., and the Expedition 345 Scientists, Proc. IODP, 345: College Station, TX (Integrated Ocean Drilling Program). doi:10.2204/iodp.proc.345.102.2014

Grove, T.L., and Bryan, W.B., 1983. Fractionation of pyroxene-phyric MORB at low pressure: an experimental study. Contrib. Mineral. Petrol., 84(4):293-309. doi:10.1007/BF01160283

Grove, T.L., Kinzler, R.J., and Bryan, W.B., 1992. Fractionation of mid-ocean ridge basalt (MORB). In Morgan, J.P., 
Blackman, D.K., and Sinton, J.M. (Eds.), Mantle Flow and Melt Generation at Mid-Ocean Ridges. Geophys. Monogr., 71:281-310. doi:10.1029/GM071p0281

Hanna, H.D., 2004. Geochemical variations in basaltic glasses from an incipient rift and upper level gabbros from Hess Deep, eastern equatorial Pacific [M.Sc. thesis]. Duke Univ., Durham.

Jelinek, V., 1981. Characterization of the magnetic fabric of rocks. Tectonophysics, 79(3-4):T63-T67. doi:10.1016/ 0040-1951(81)90110-4

Kirchner, T.M., and Gillis, K.M., 2012. Mineralogical and strontium isotopic record of hydrothermal processes in the lower ocean crust at and near the East Pacific Rise. Contrib. Mineral. Petrol., 164(1):123-141 doi:10.1007/ s00410-012-0729-5

Kirschvink, J.L., 1980. The least-squares line and plane and the analysis of palaeomagnetic data. Geophys. J. R. Astron. Soc., 62(3):699-718. doi:10.1111/j.1365246X.1980.tb02601.X

Melson, W.G., and Thompson, G., 1970. Layered basic complex in oceanic crust, Romanche fracture, equatorial Atlantic Ocean. Science, 168(3933):817-820. doi:10.1126/science.168.3933.817

Meyer, P.S., Dick, H.J.B., and Thompson, G., 1989. Cumulate gabbros from the Southwest Indian Ridge, $54^{\circ} \mathrm{S}-$ $7^{\circ} 16^{\prime} \mathrm{E}$ : implications for magmatic processes at a slow spreading ridge. Contrib. Mineral. Petrol., 103(1):44-63. doi:10.1007/BF00371364

Miller, D.J., Iturrino, G.J., and Christensen, N.I., 1996. Geochemical and petrological constraints on velocity behavior of lower crustal and upper mantle rocks from the fast-spreading ridge at Hess Deep. In Mével, C., Gillis, K.M., Allan, J.F., and Meyer, P.S. (Eds.), Proc. ODP, Sci. Results, 147: College Station, TX (Ocean Drilling Program), 477-490. doi:10.2973/ odp.proc.sr.147.028.1996

Morris, A., Gee, J.S., Pressling, N., John, B.E., MacLeod, C.J., Grimes, C.B., and Searle, R.C., 2009. Footwall rotation in an oceanic core complex quantified using reoriented Integrated Ocean Drilling Program core samples. Earth Planet. Sci. Lett., 287(1-2):217-228. doi:10.1016/ j.epsl.2009.08.007

Natland, J.H., and Dick, H.J.B., 2009. Paired melt lenses at the East Pacific Rise and the pattern of melt flow through the gabbroic layer at a fast-spreading ridge. Lithos, 112(1-2):73-86. doi:10.1016/ j.lithos.2009.06.017
Nozaka, T., and Fryer, P., 2011. Alteration of the oceanic lower crust at a slow-spreading axis: insight from veinrelated zoned halos in olivine gabbro from Atlantis Massif, Mid-Atlantic Ridge. J. Petrol., 52(4):643-664. doi:10.1093/petrology/egq098

Passchier, C.W., and Trouw, R.A.J., 2005. Microtectonics (2nd ed.): Berlin (Springer).

Pedersen, R.B., Malpas, J., and Falloon, T., 1996. Petrology and geochemistry of gabbroic and related rocks from Site 894, Hess Deep. In Mével, C., Gillis, K.M., Allan, J.F., and Meyer, P.S. (Eds.), Proc. ODP, Sci. Results, 147: College Station, TX (Ocean Drilling Program), 3-19. doi:10.2973/odp.proc.sr.147.001.1996

Perk, N.W., Coogan, L.A., Karson, J.A., Klein, E.M., and Hanna, H.D., 2007. Petrology and geochemistry of primitive lower oceanic crust from Pito Deep: implications for the accretion of the lower crust at the southern East Pacific Rise. Contrib. Mineral. Petrol., 154(5):575590. doi:10.1007/s00410-007-0210-z

Rioux, M., Lissenberg, C.J., McLean, N.M., Bowring, S.A., MacLeod, C.J., Hellebrand, E., and Shimizu, N., 2012. Protracted timescales of lower crustal growth at the fastspreading East Pacific Rise. Nat. Geosci., 5(4):275-278. doi:10.1038/ngeo1378

Shipboard Scientific Party, 1989. Site 735. In Robinson, P.T., Von Herzen, R., et al., Proc. ODP, Init. Repts., 118: College Station, TX (Ocean Drilling Program), 89-222. doi:10.2973/odp.proc.ir.118.107.1989

Shipboard Scientific Party, 1993. Site 894. In Gillis, K., Mével, C, Allan, J., et al., Proc. ODP, Init. Repts., 147: College Station, TX (Ocean Drilling Program), 45-108. doi:10.2973/odp.proc.ir.147.103.1993

Shipboard Scientific Party, 1999. Site 735. In Dick, H.J.B., Natland, J.H., Miller, D.J., et al., Proc. ODP, Init. Repts., 176: College Station, TX (Ocean Drilling Program), 1314. doi:10.2973/odp.proc.ir.176.103.1999

Shipboard Scientific Party, 2004. Site 1271. In Kelemen, P.B., Kikawa, E., Miller, D.J., et al., Proc. ODP, Init. Repts., 209: College Station, TX (Ocean Drilling Program), 1129. doi:10.2973/odp.proc.ir.209.106.2004

Tarling, D.H., 1983. Palaeomagnetism, Principles and Applications in Geology, Geophysics and Archaeology: New York (Chapman and Hall).

Publication: 12 February 2014 MS 345-109 
Figure F1. A. Core recovery and principal lithologies, Hole U1415I. B. Rock types recovered from lithologic Units I (rubble zone) and II (Layered Gabbro Series) and ghost core. For clarity, only the principal rock names are shown without any modifier. $\mathrm{Ol}=$ olivine.
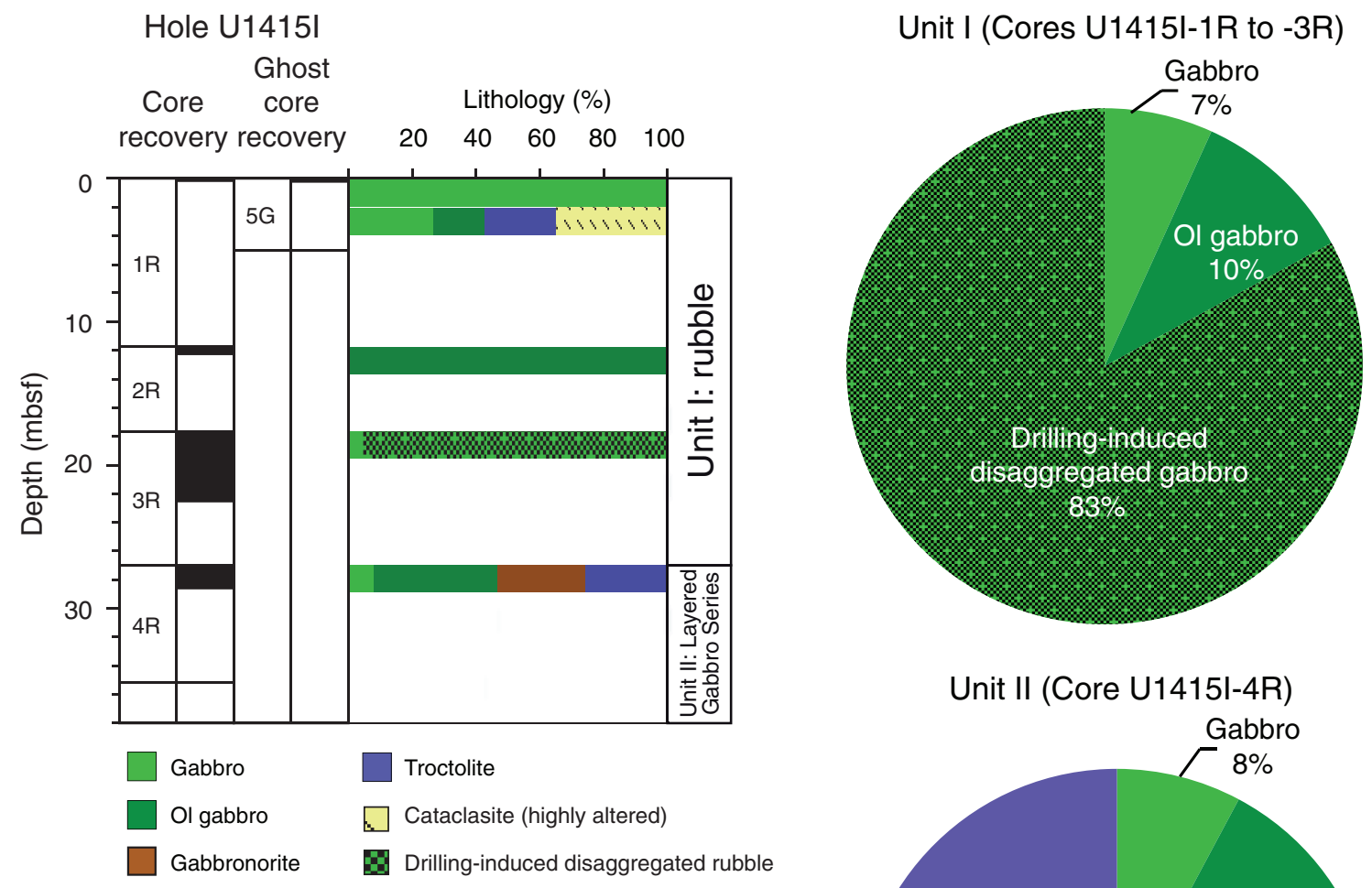

\section{Unit II (Core U1415I-4R)}

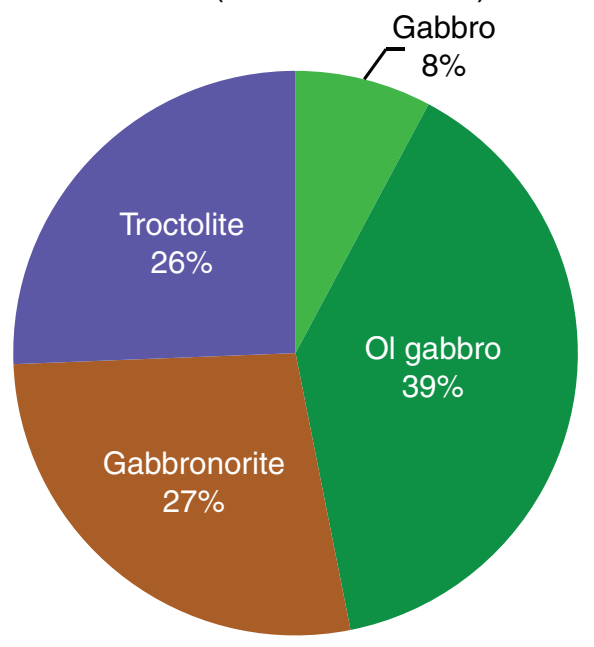

Ghost core (Core U1415I-5G)

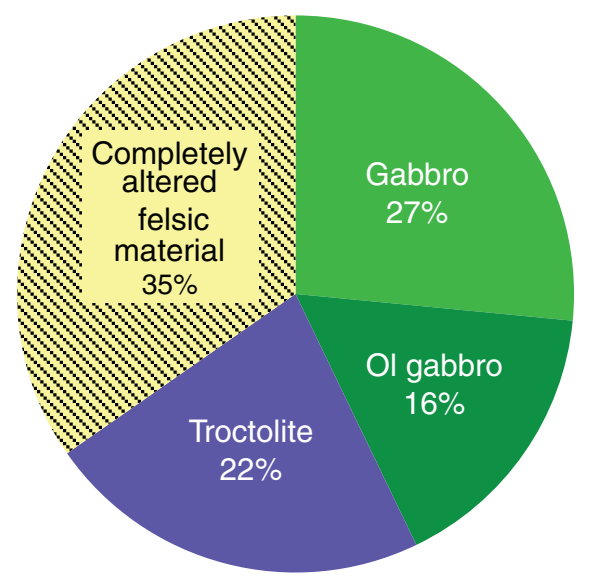


Figure F2. Boundary between olivine gabbro (Interval 15) and olivine-bearing gabbronorite (Interval 16) (Thin Section 21; Sample 345-U1415I-4R-1, 31-40 cm [Piece 6]) in the layered series of lithologic Unit II. A. Core close-up. Red box indicates the position from which the thin section shown in B and C was cut. B. Note the sutured boundary (arrows) without any discontinuity between domains. A moderate to strong magmatic foliation is visible and mainly defined by subparallel alignment of tabular plagioclase and elongated anhedral olivine in olivine gabbro. Contact between the two lithologies is parallel to the foliation and sutured, implying the coexistence of two lithologically different crystal mushes in the hyper solidus regime. The type of the contact is modal, in combination with a slight change in average plagioclase grain size ( $2 \mathrm{~mm}$ in olivine-bearing gabbronorite; $2.5 \mathrm{~mm}$ in olivine gabbro. Plane-polarized light. C. Under crossed polars.

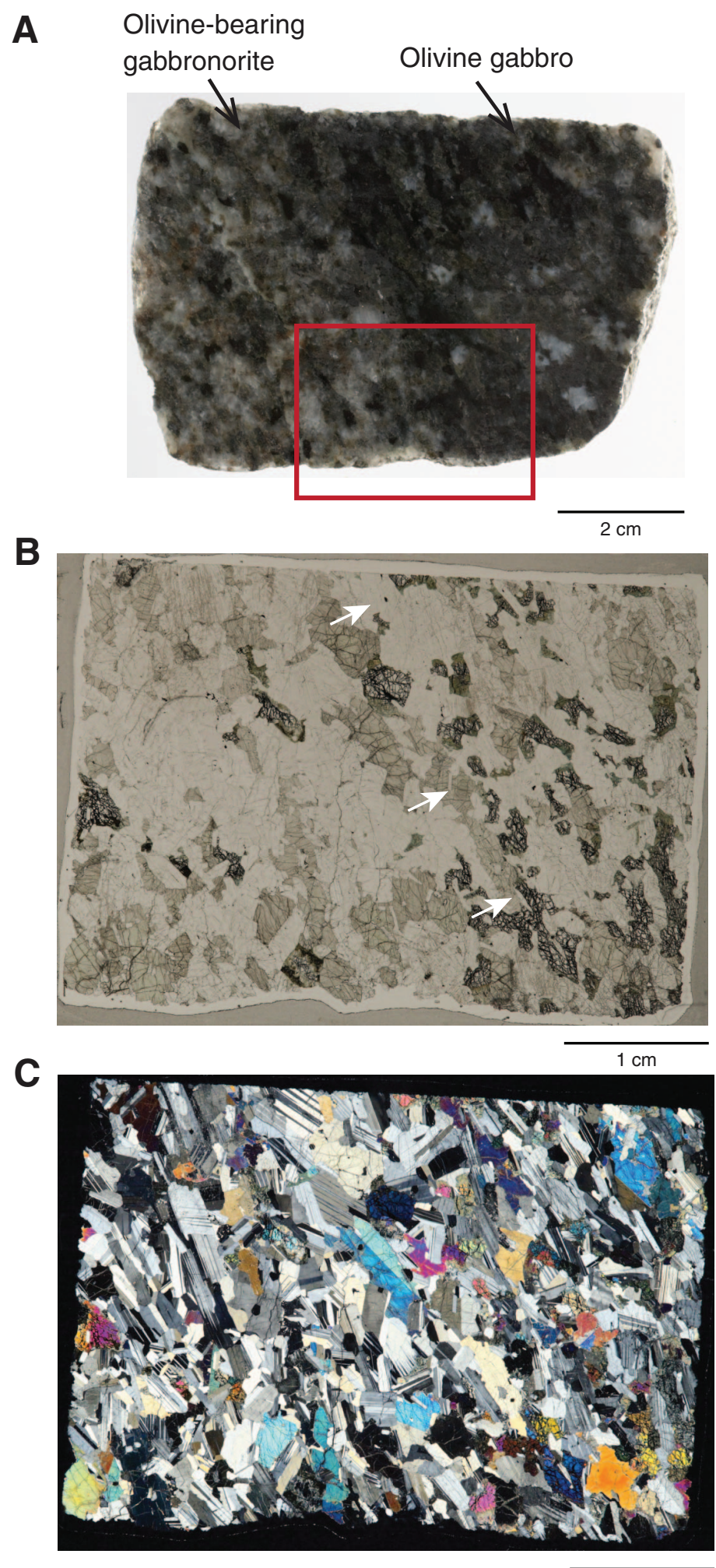


Figure F3. Troctolite layer surrounded by olivine-bearing gabbronorite and olivine gabbro (Sample 345U1415I-4R-1, 65-78 cm [Piece 8]). Boundaries between the troctolite and adjacent rock are indicated by arrows and correspond to modal changes in combination with slight changes in grain size and texture.

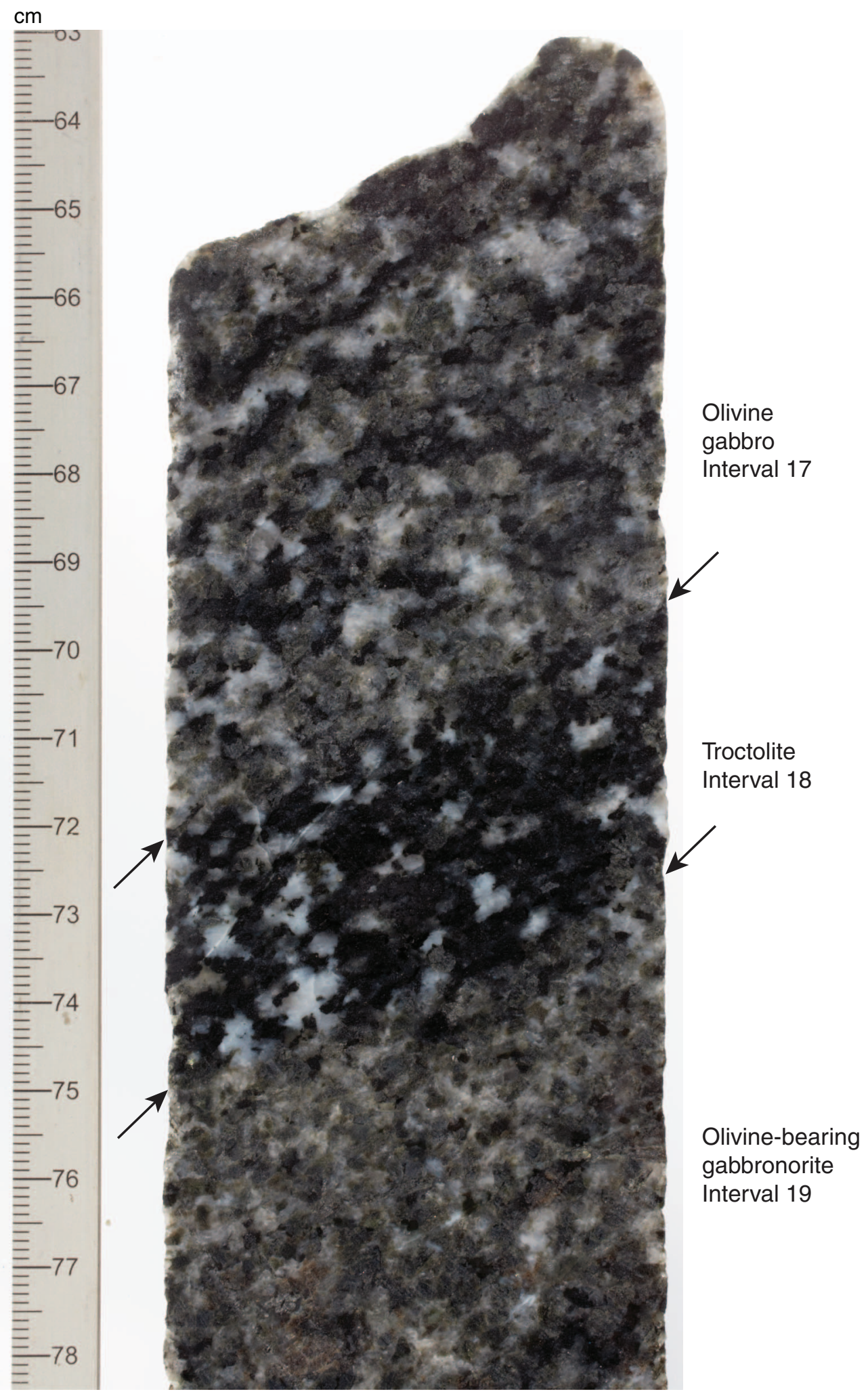


Figure F4. Clinopyroxene oikocryst-bearing troctolite (Sample 345-U1415I-4R-2, 9-13 cm [Piece 2]). Note the equant shape and subhedral outline of the clinopyroxene oikocryst. The plagioclase grains in the troctolite are subparallel and aligned parallel to the foliation of the rock, whereas the plagioclase chadacrysts in clinopyroxene show random orientation. For more details see Figures F5 and F10. A. Core close-up. B. Plane-polarized light. C. Under crossed polars.

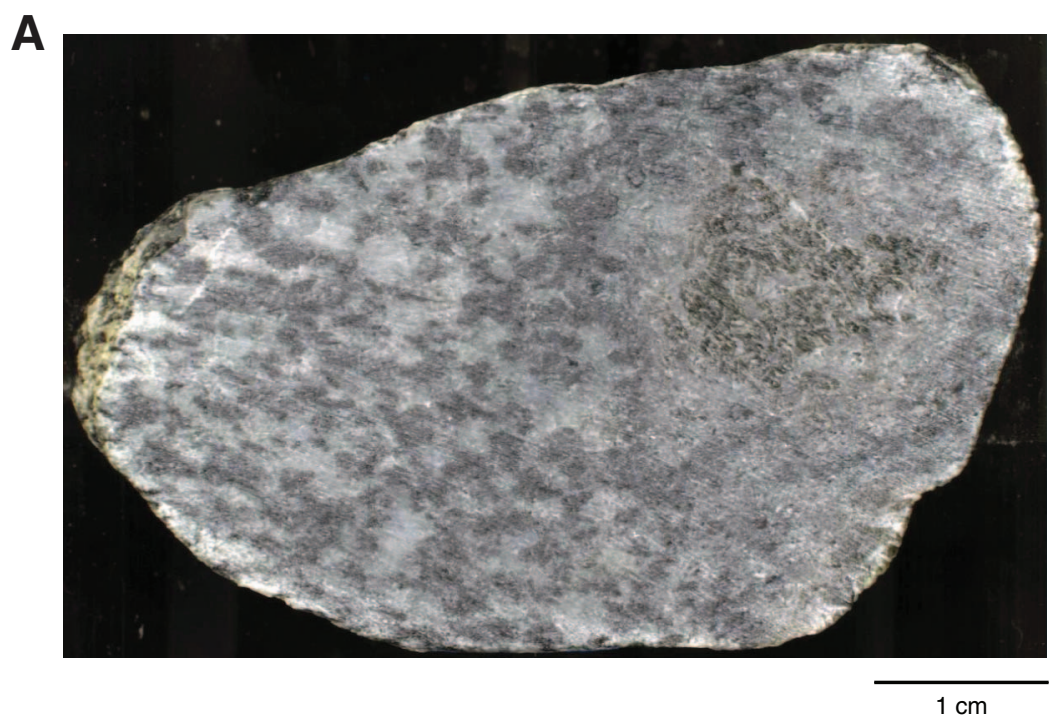

B
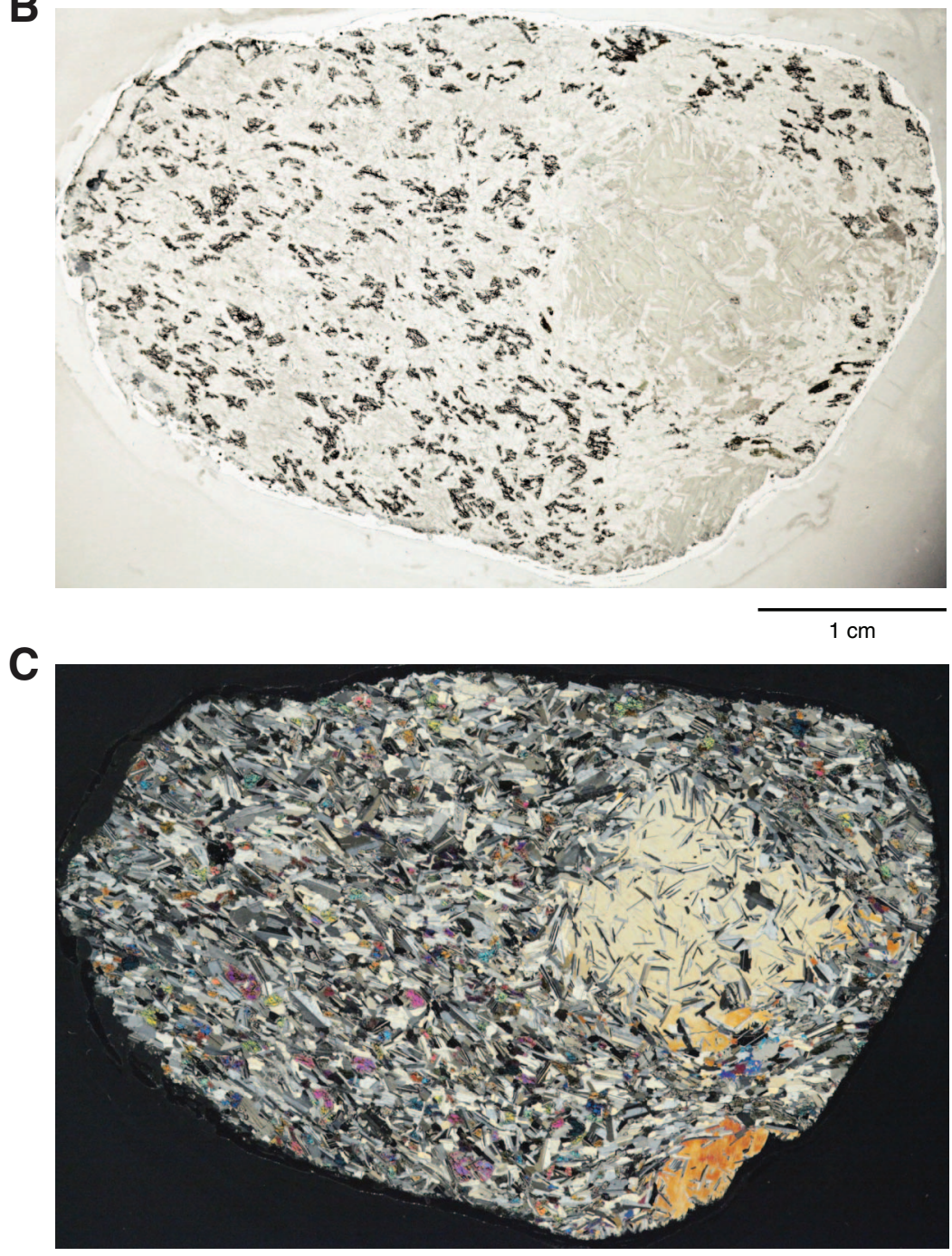
Figure F5. Gabbro (Thin Section 18; Sample 345-U1415I-3R-4, 14-22 cm [Piece 2]). A. Core close-up. Red box indicates the position from which the thin section was cut. B. Plane-polarized light. Note the presence of clinopyroxene oikocrysts (arrows) enclosing plagioclase chadacrysts in random orientation, similar to the matrix plagioclase. See also Figure F9A. C. Under crossed polars.

A

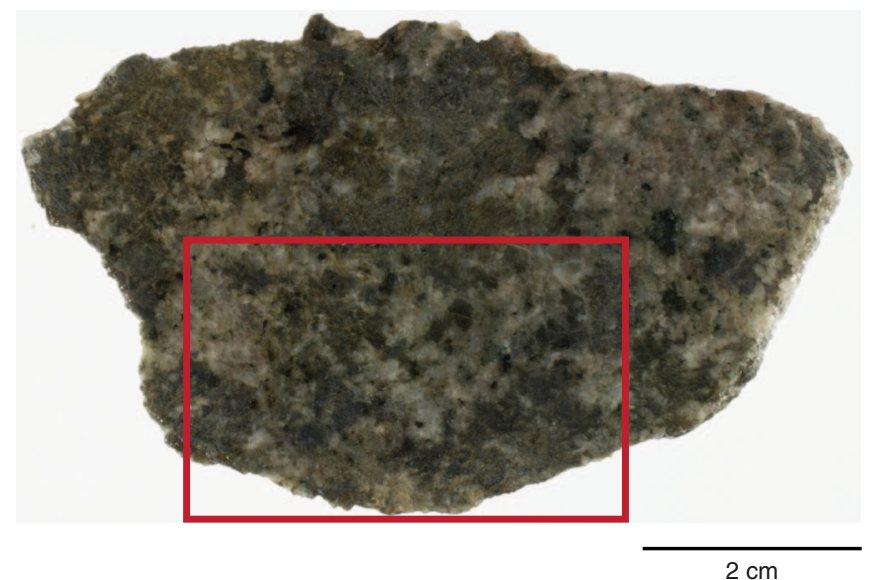

B

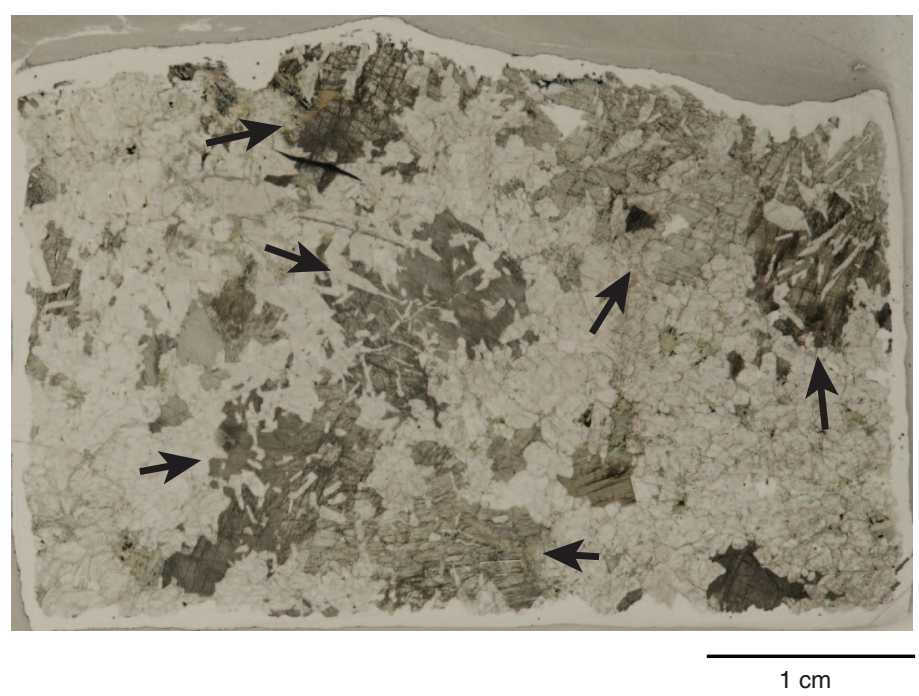

C

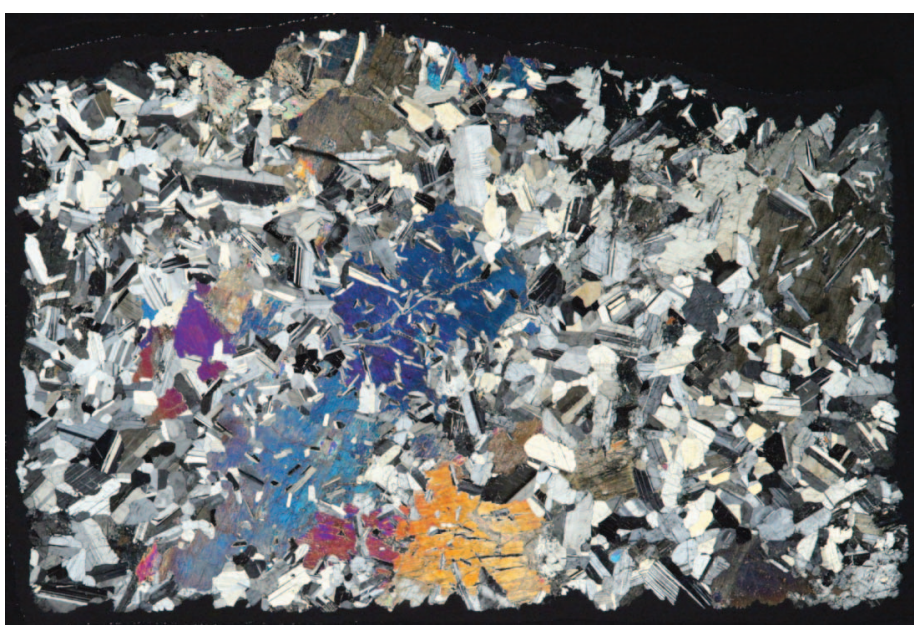

$1 \mathrm{~cm}$ 
Figure F6. Olivine-bearing gabbronorite (Thin Section 22; Sample 345-U1415I-4R-1, 47-58 cm [Piece 8A]). Note the subparallel alignment of tabular plagioclase and clinopyroxene following foliation of the rock. A. Core close-up image. Red box indicates the position from which the thin section was cut. B. Plane-polarized light. C. Under crossed polars.

A

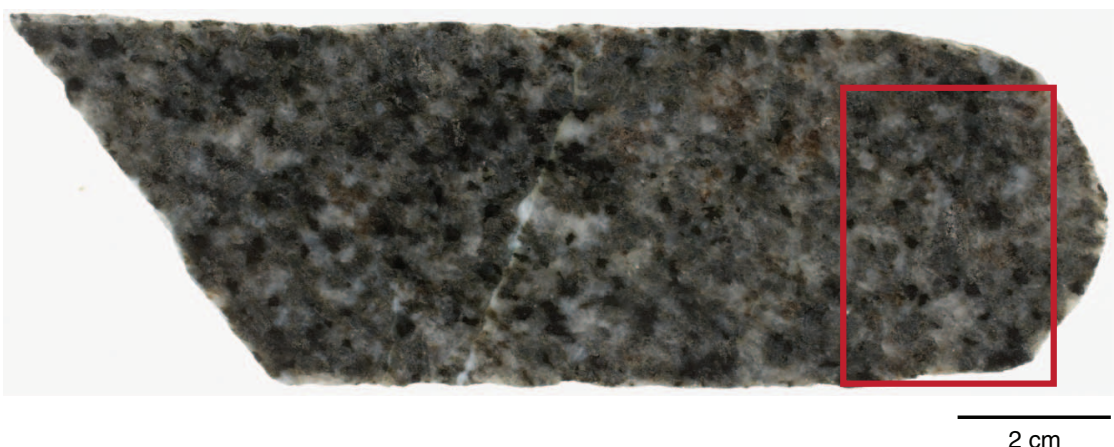

B

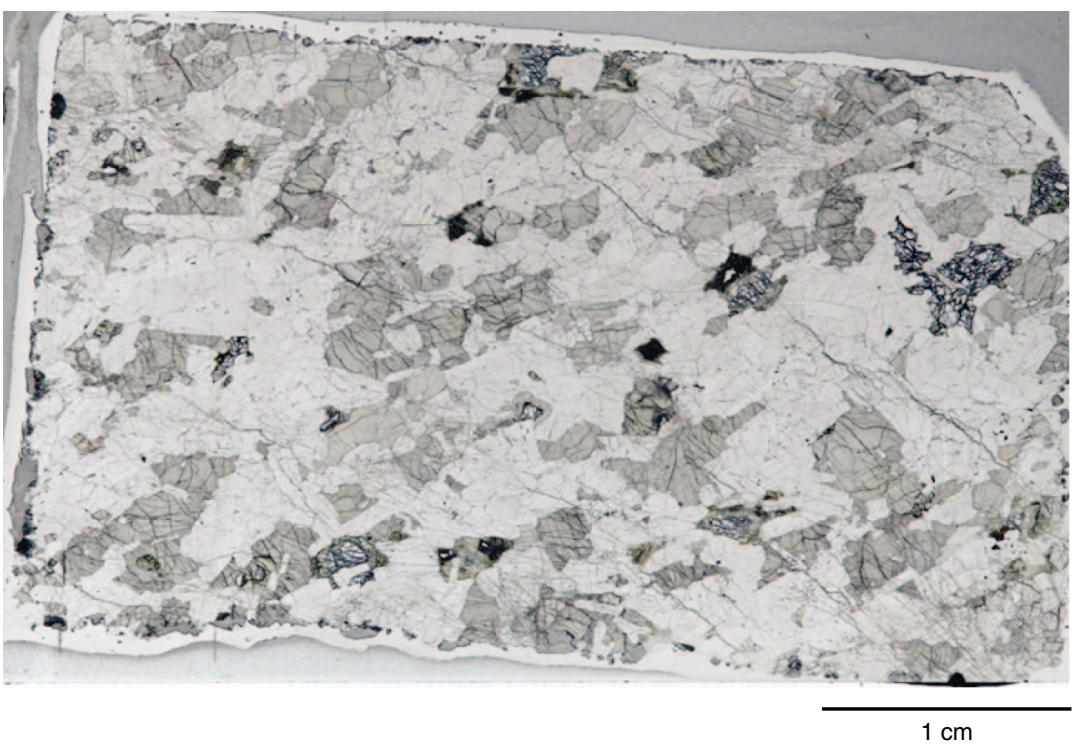

C

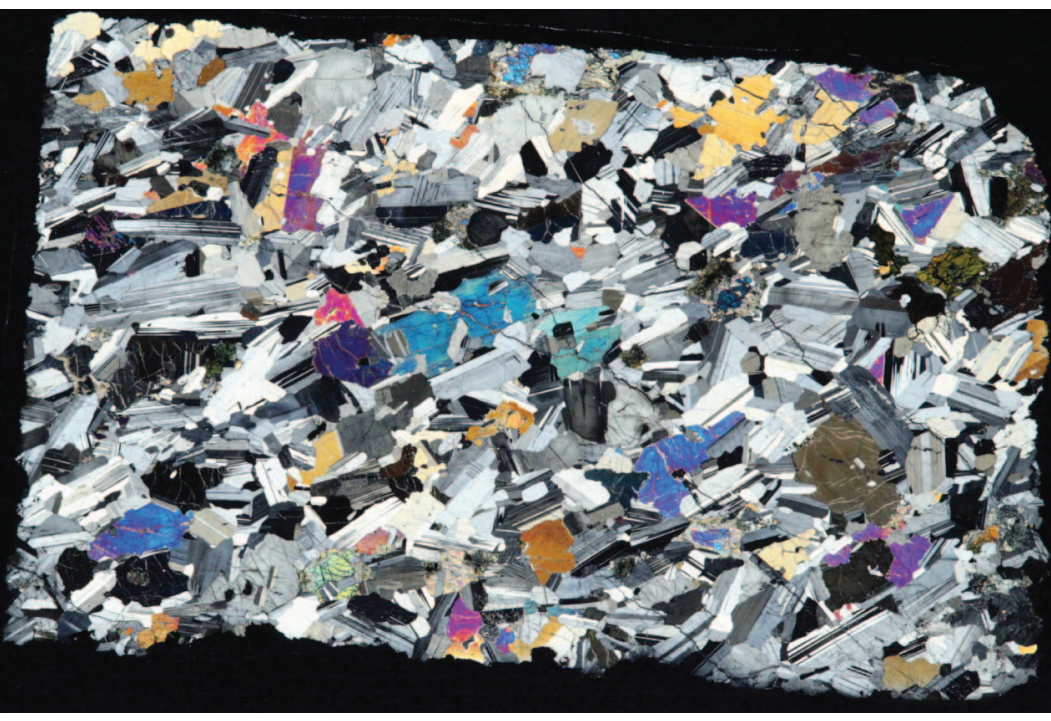

$1 \mathrm{~cm}$ 
Figure F7. Coherent series of layered gabbro of lithologic Unit II (interval 345-U1415I-4R-1, 33-143 cm). Included are the igneous boundaries (red dashed lines) separating the different lithologic intervals (Intervals 1422) with the corresponding rock names based on modal estimations. For details, see Table T2.

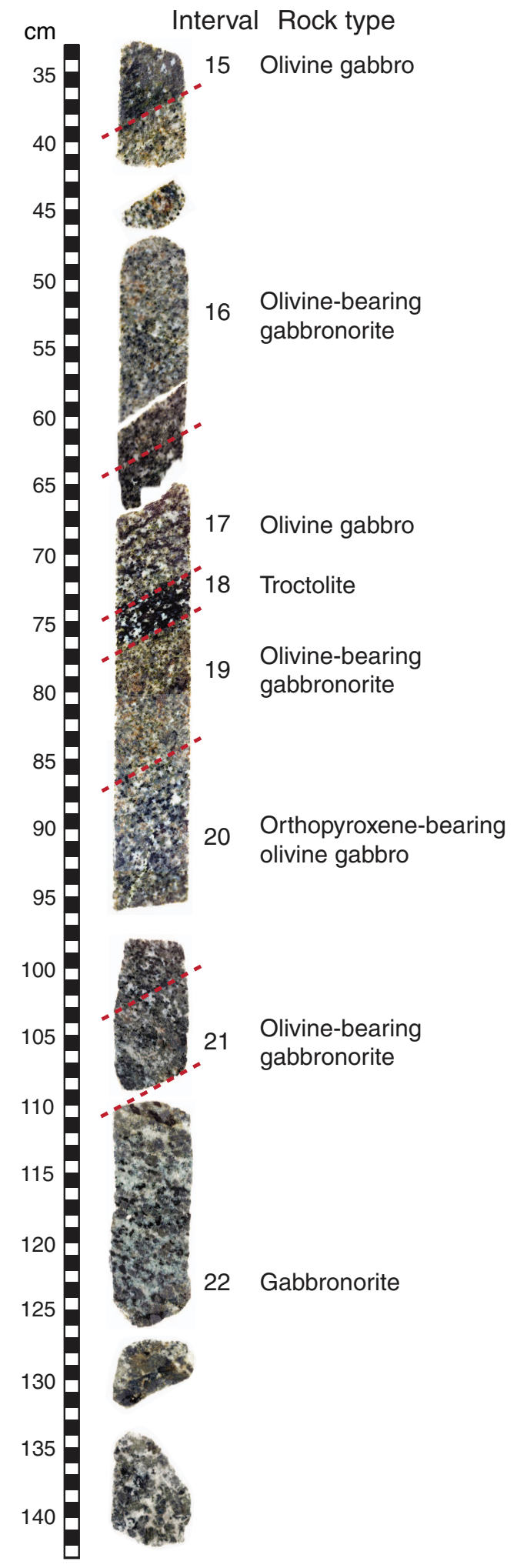


Figure F8. Mode estimation details for Intervals 16-18 (interval 345-U1415I-4R-1, 38-77 cm). Opx = orthopyroxene, $\mathrm{Pl}=$ plagioclase, $\mathrm{Cpx}=$ clinopyroxene, $\mathrm{Ol}=$ olivine. A. Enhanced digital image of the relevant part of the section (Pieces 6, 7, and 8). Images were enhanced with Adobe Photoshop CS5 using the brightness (values between +100 and +120 ) and vibrance (value $=+50$ ) parameters and the auto tone, auto contrast, and auto color functions. B. Estimation of modal contents in $1 \mathrm{~cm}$ intervals parallel to the layering. C. Estimation of grain size.

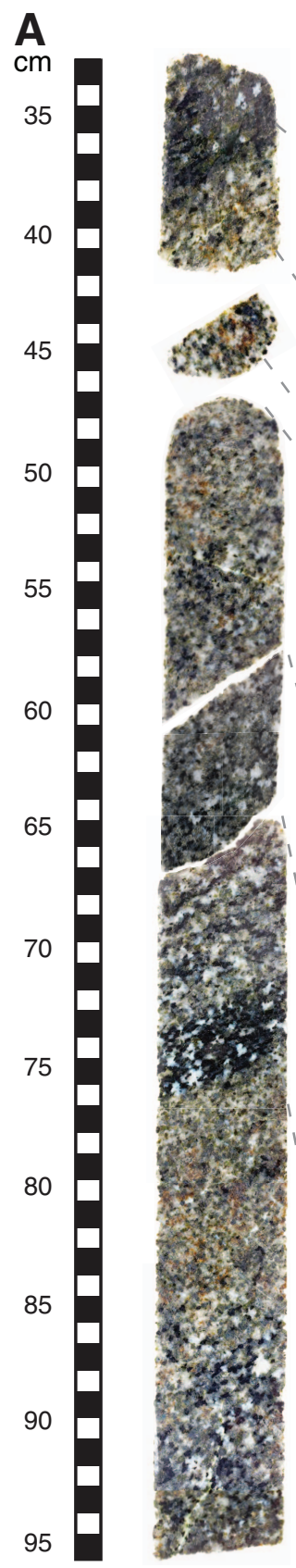

\section{Section 345-U1415-4R-1}

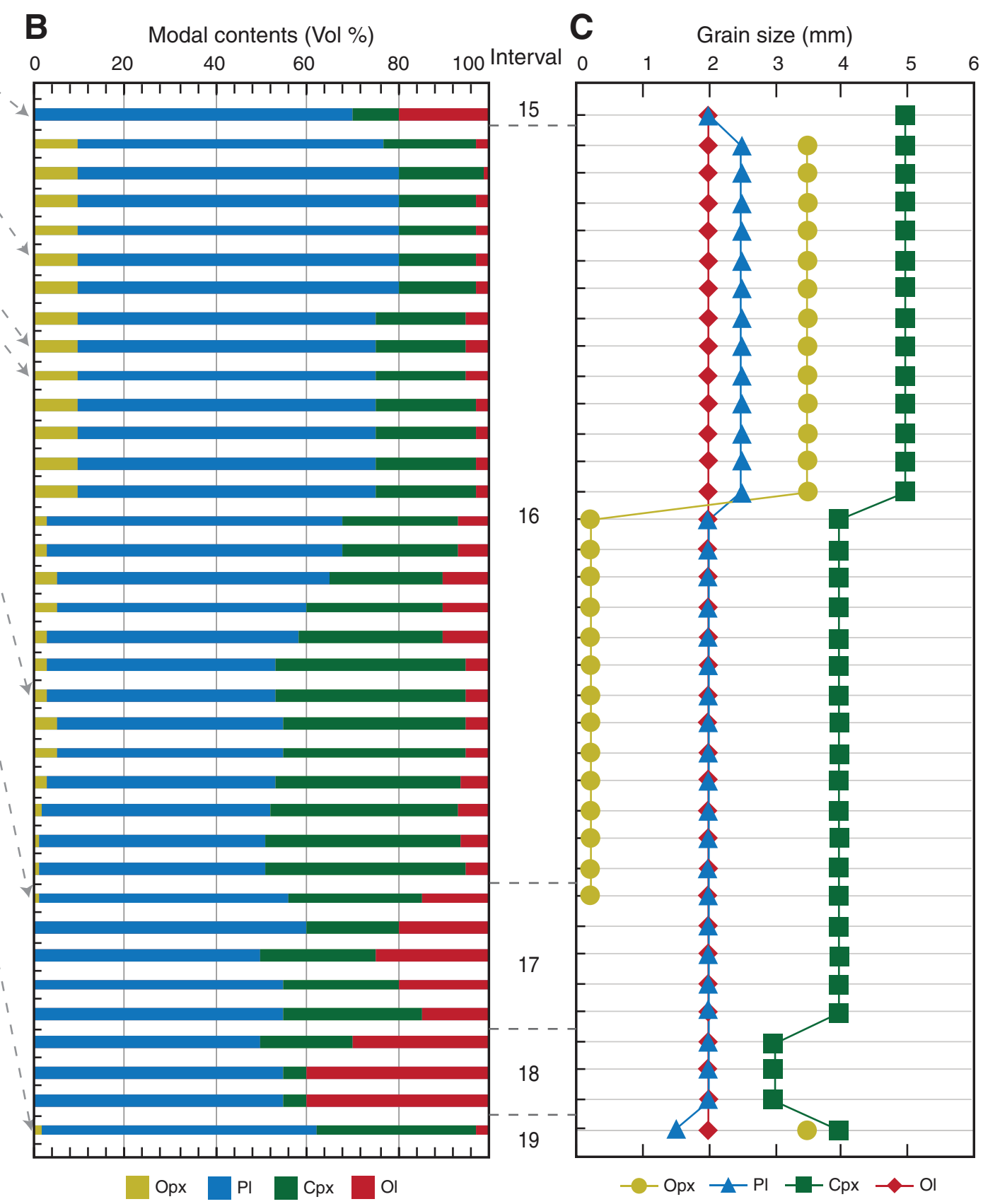


Figure F9. Images of qualitative estimation of crystal-preferred orientation of plagioclase crystals in clinopyroxene oikocrysts and corresponding matrix rock by manual outlining of the long axis of plagioclase for two different samples. Images on the left show the drawn outlines of elongated plagioclase; images on the right show the corresponding thin section microphotographs (under crossed polars). For details, see text. A. Gabbro matrix rock (Thin Section 18; Sample 345-U1415I-3R-4, 16-19 cm [Piece 2]). B. Troctolite matrix rock (Thin Section 19; Sample 345-U1415I-4R-2, 9-13 cm [Piece 2]).

A Thin Section 18; 345-U1415I-3R-4W, 16-19 cm, Piece 2
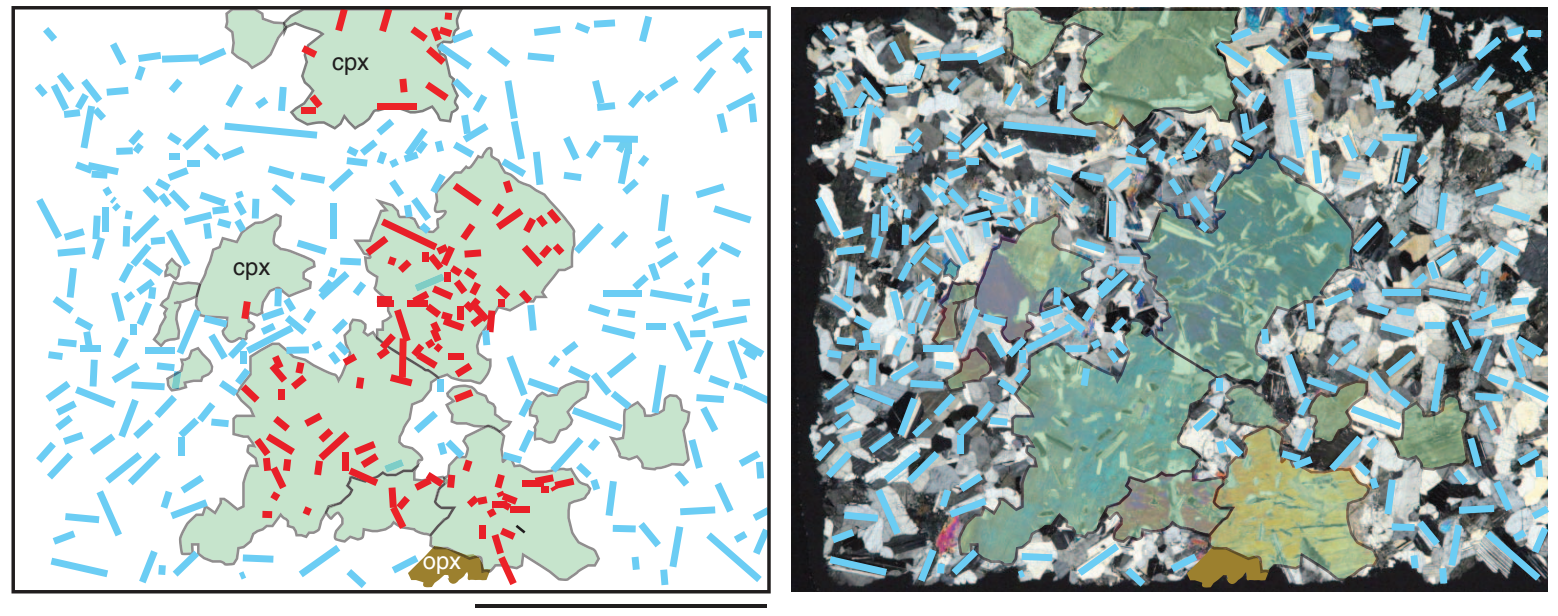

B Thin Section 19; 345-U1415I-4R-2W, 9-13 cm, Piece 2
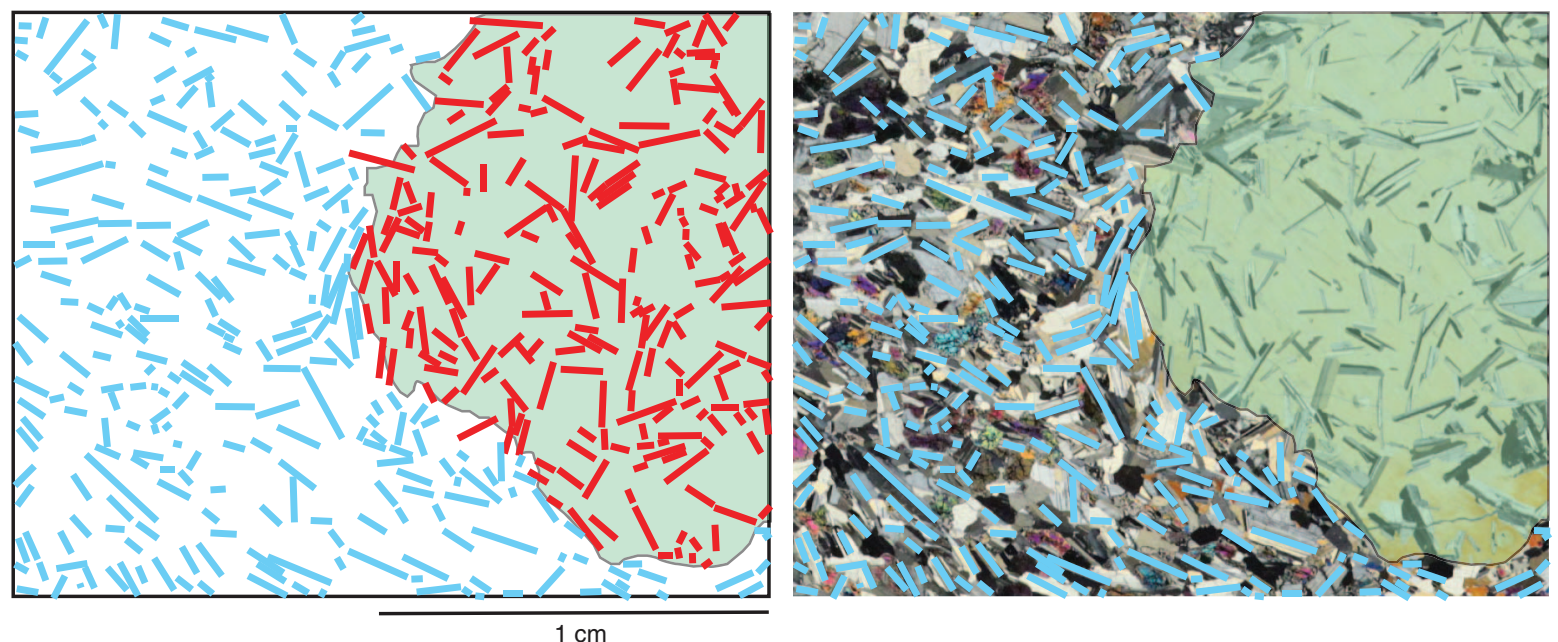
Figure F10. (A) Strongly patchy zoned plagioclase (Pl) both in the (B) troctolite matrix as well as in the (C) clinopyroxene (Cpx) oikocryst (Thin Section 19; Sample 345-U1415I-4R-2, 9-13 cm [Piece 2]; under crossed polars). Arrows in A indicate location within the thin section.

\section{A}

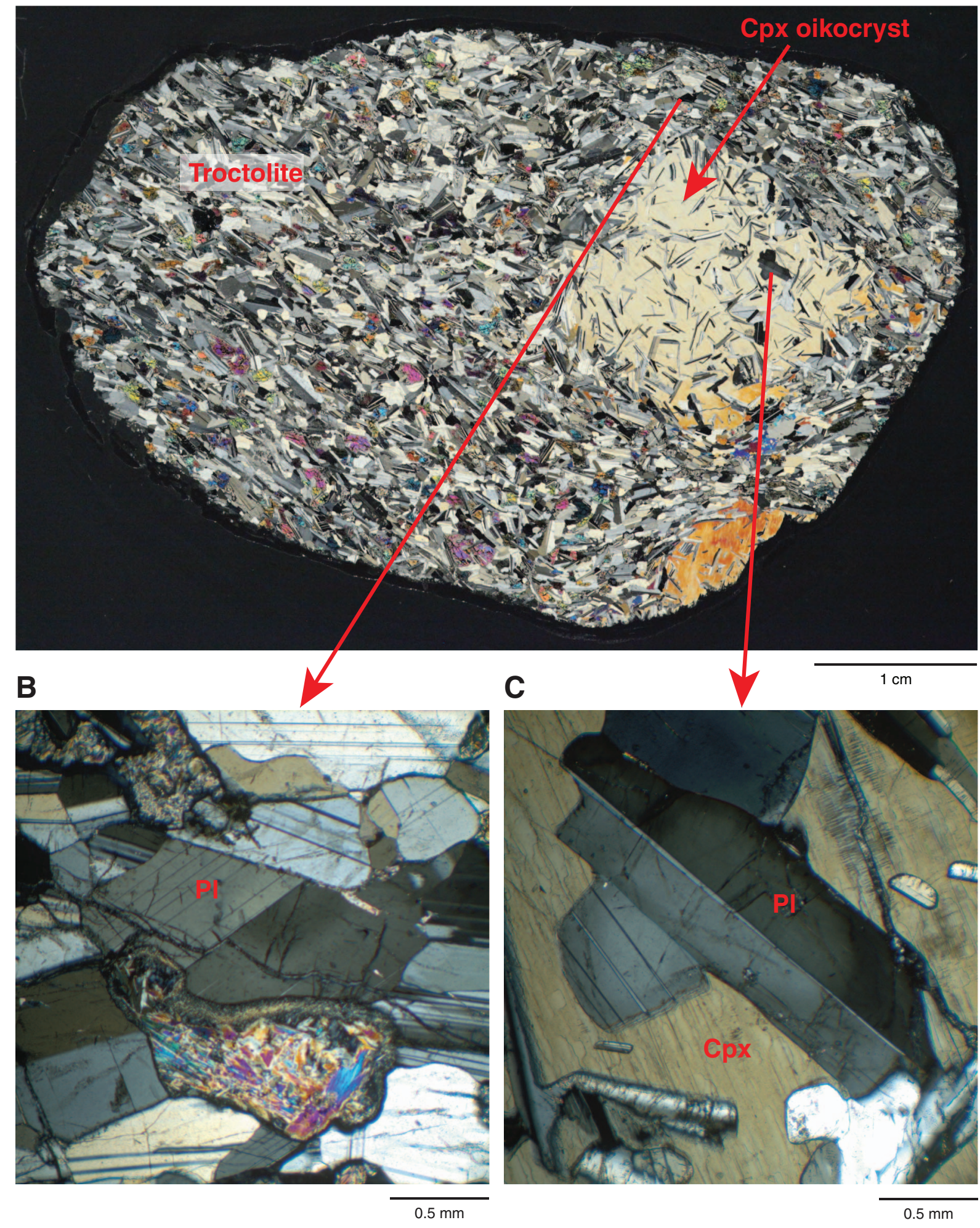


Figure F11. Troctolitic olivine gabbro with radial cracks in plagioclase (Pl). A, B. Radial cracks interpreted as resulting from the apparent volume increase associated with serpentinization (Serp) of olivine (Ol) (Thin Section 21; Sample 345-U1415I-4R-1, 35-38 cm) C, D. Radial cracks interpreted as resulting from corona formation; olivine is replaced by tremolite (Tr) and chlorite (Chl) (Thin Section 14; Sample 345-U1415I-2R-1, 51$53 \mathrm{~cm}$ [Piece 11]). A and C are under plane-polarized light; B and D are under crossed polars.

A

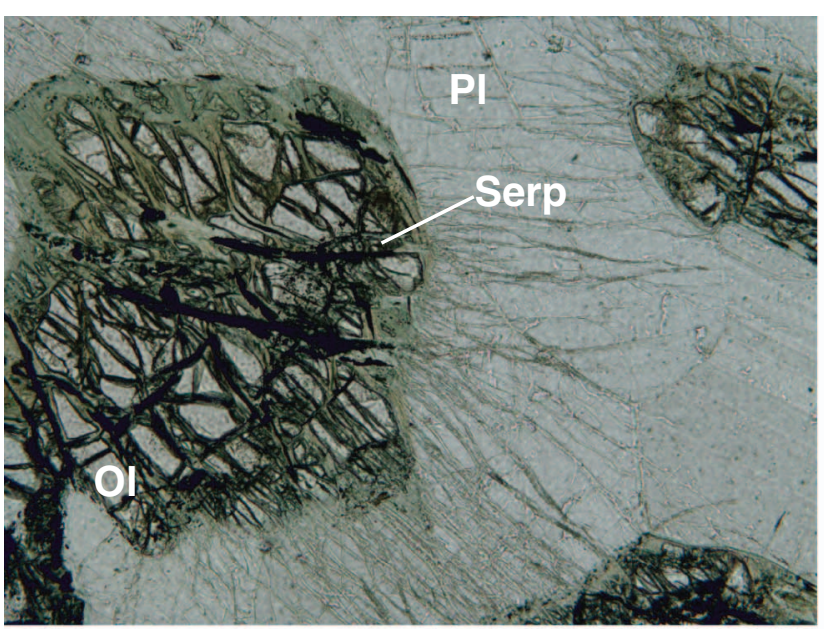

$0.25 \mathrm{~mm}$

C

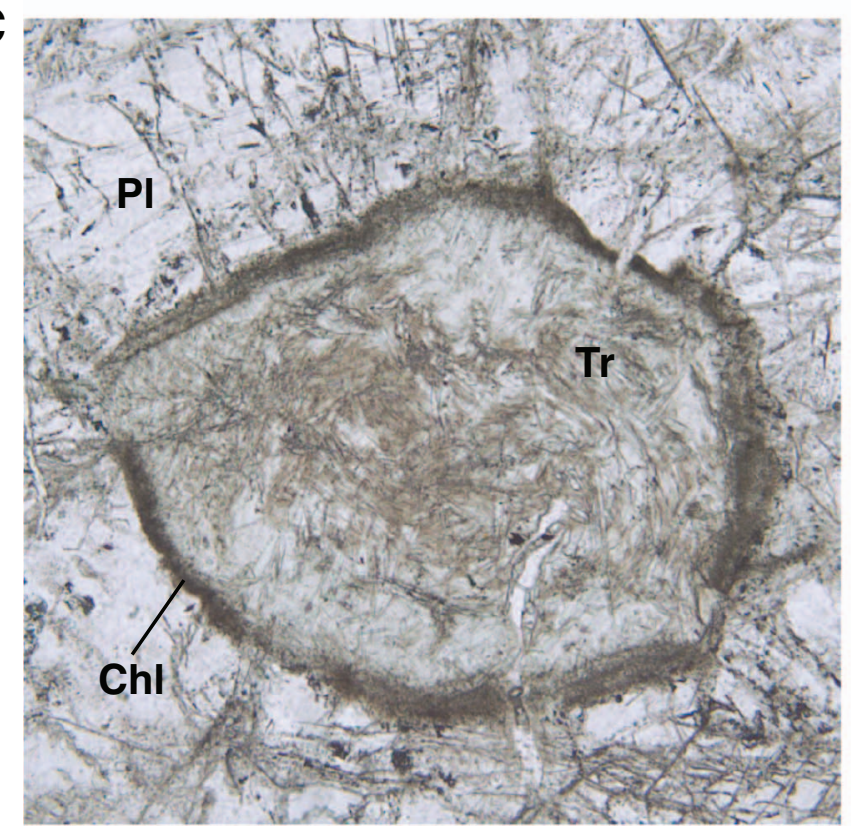

$0.25 \mathrm{~mm}$
B

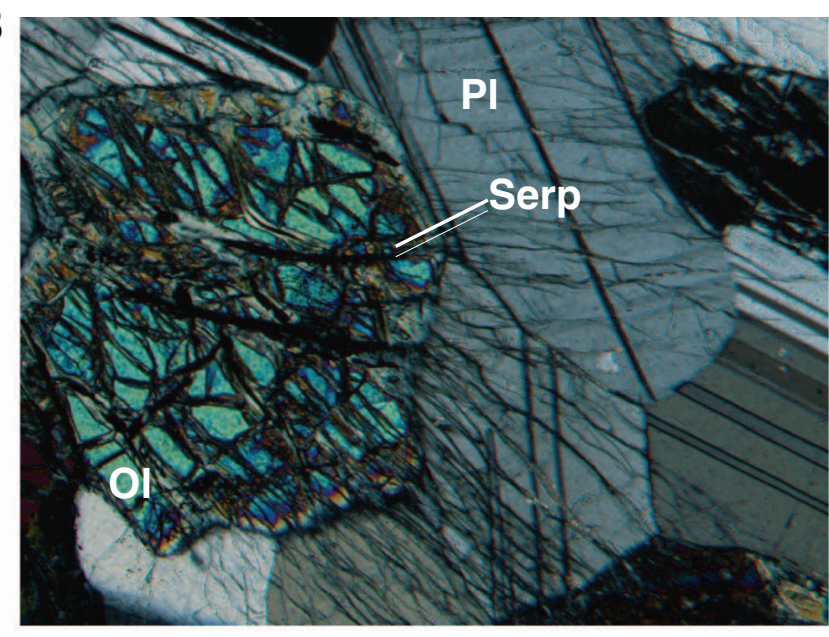

$0.25 \mathrm{~mm}$

D

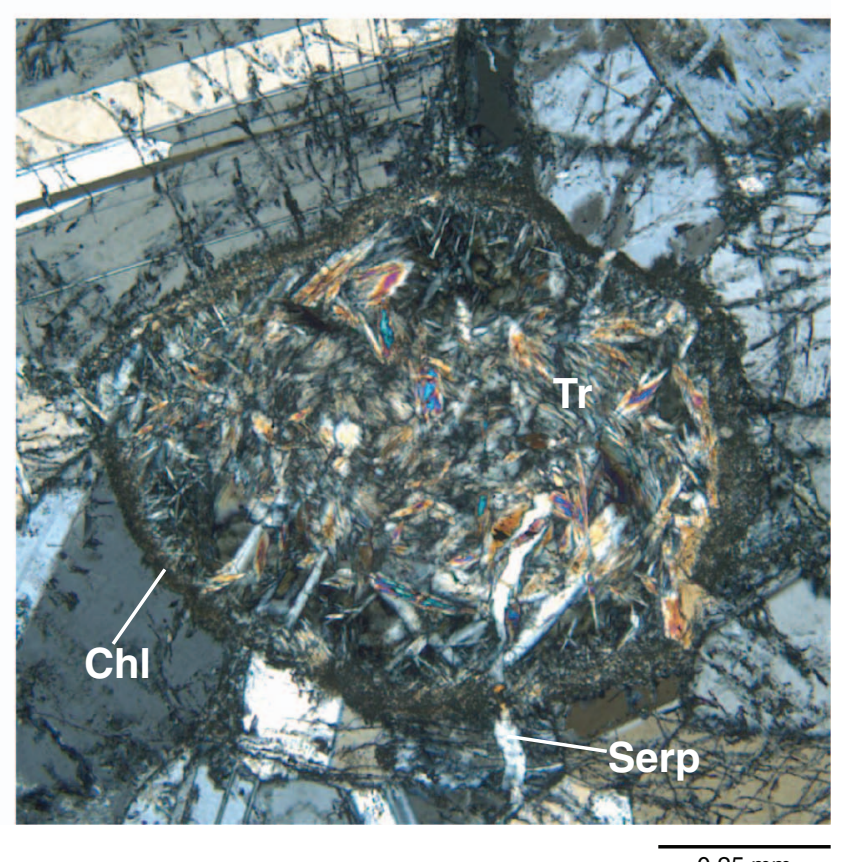


Figure F12. Plagioclase (Pl) alteration to prehnite (Preh) along fractures associated with serpentinization of olivine $(\mathrm{Ol})$ in troctolitic olivine gabbro (Thin Section 21; Sample 345-U1415I-4R-1, 35-38 cm). A. Plane-polarized light. B. Under crossed polars.

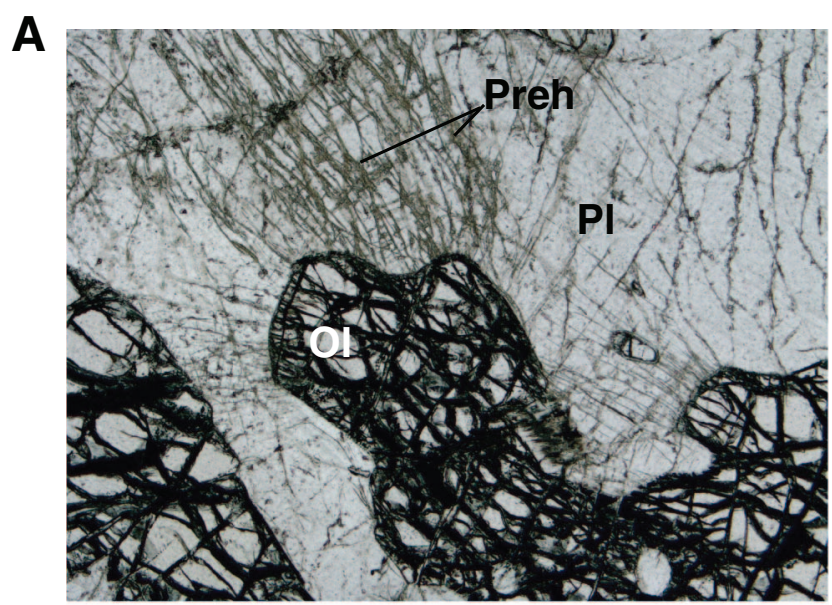

$0.5 \mathrm{~mm}$
B

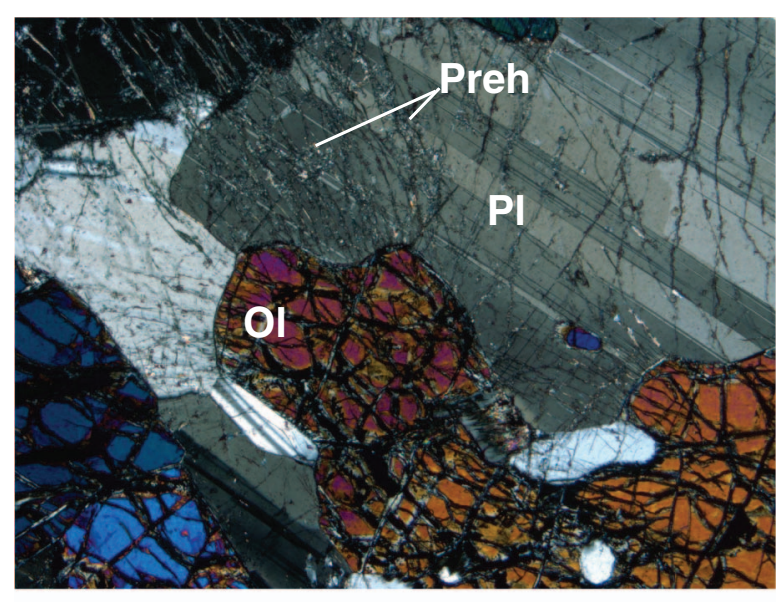

$0.5 \mathrm{~mm}$ 
Figure F13. A. Prehnite (Preh) vein in olivine gabbro cutting serpentinized olivine (Sample 345-U1415I-2R-1A, 49-60 cm [Piece 11]). B. Cataclastic zone in olivine gabbro, altered to prehnite and cut by zeolite (Ze) and prehnite veinlets (Sample 345-U1415I-2R-1A, 24.5-31.5 cm [Piece 7]). C. Prehnite + serpentine (Serp) vein cutting serpentinized olivine and plagioclase in olivine-bearing gabbro (Sample 345-U1415I-4R-1A, 83-97 cm [Piece 8C]).

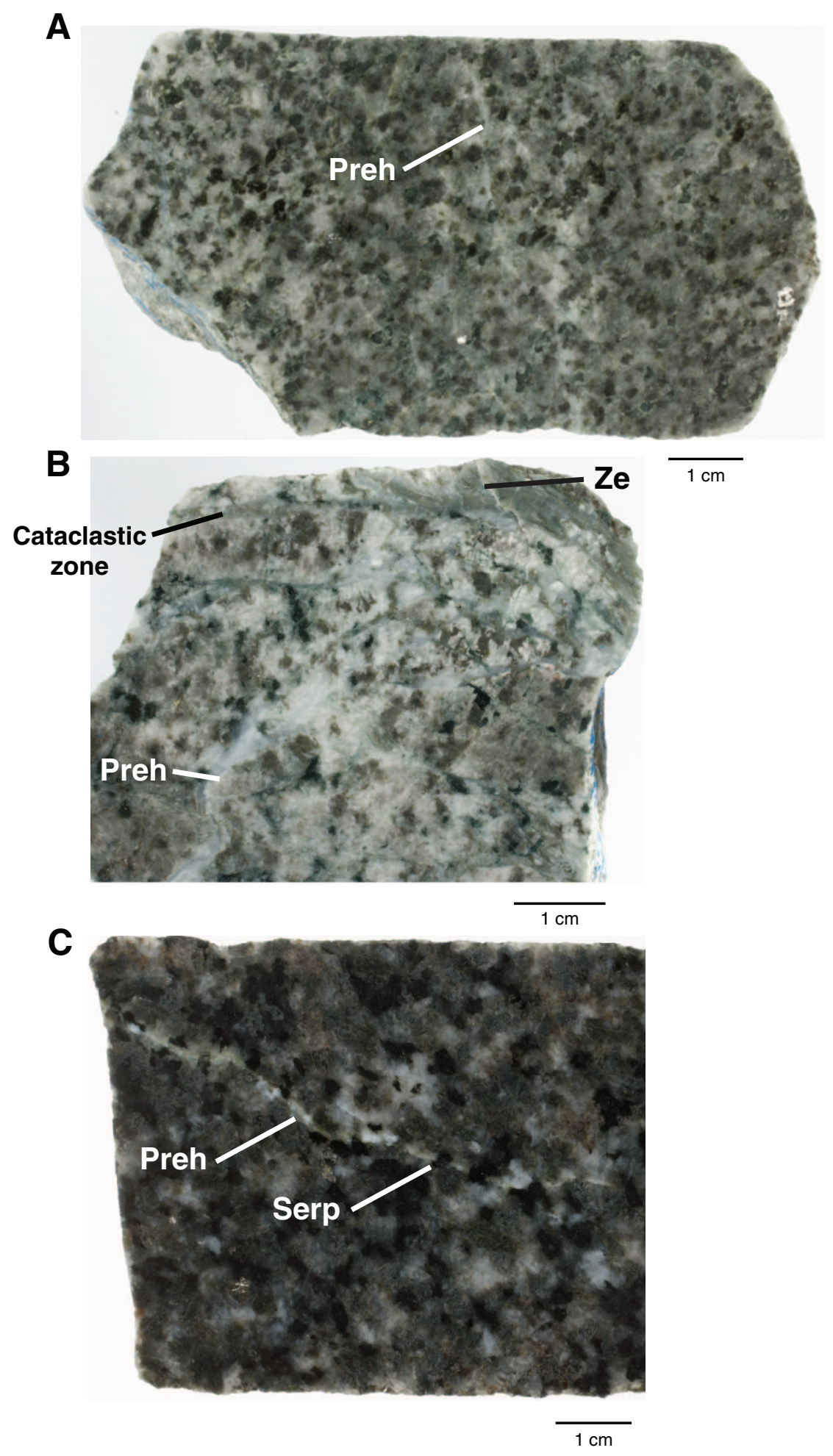


Figure F14. Veins and cataclastic zones in olivine gabbro (Thin Section 13; Sample 345-U1415I-2R-1, 25-31 $\mathrm{cm})$. A, B. Prehnite (Preh) veins with tension gashes cutting highly altered olivine gabbro. C, D. Prehnite replacing comminuted plagioclase $(\mathrm{Pl})$ in cataclasite $\mathrm{Cpx}=$ clinopyroxene, $\mathrm{Ol}=$ olivine. $\mathrm{A}$ and $\mathrm{C}$ are under planepolarized light; B and D are under crossed polars.
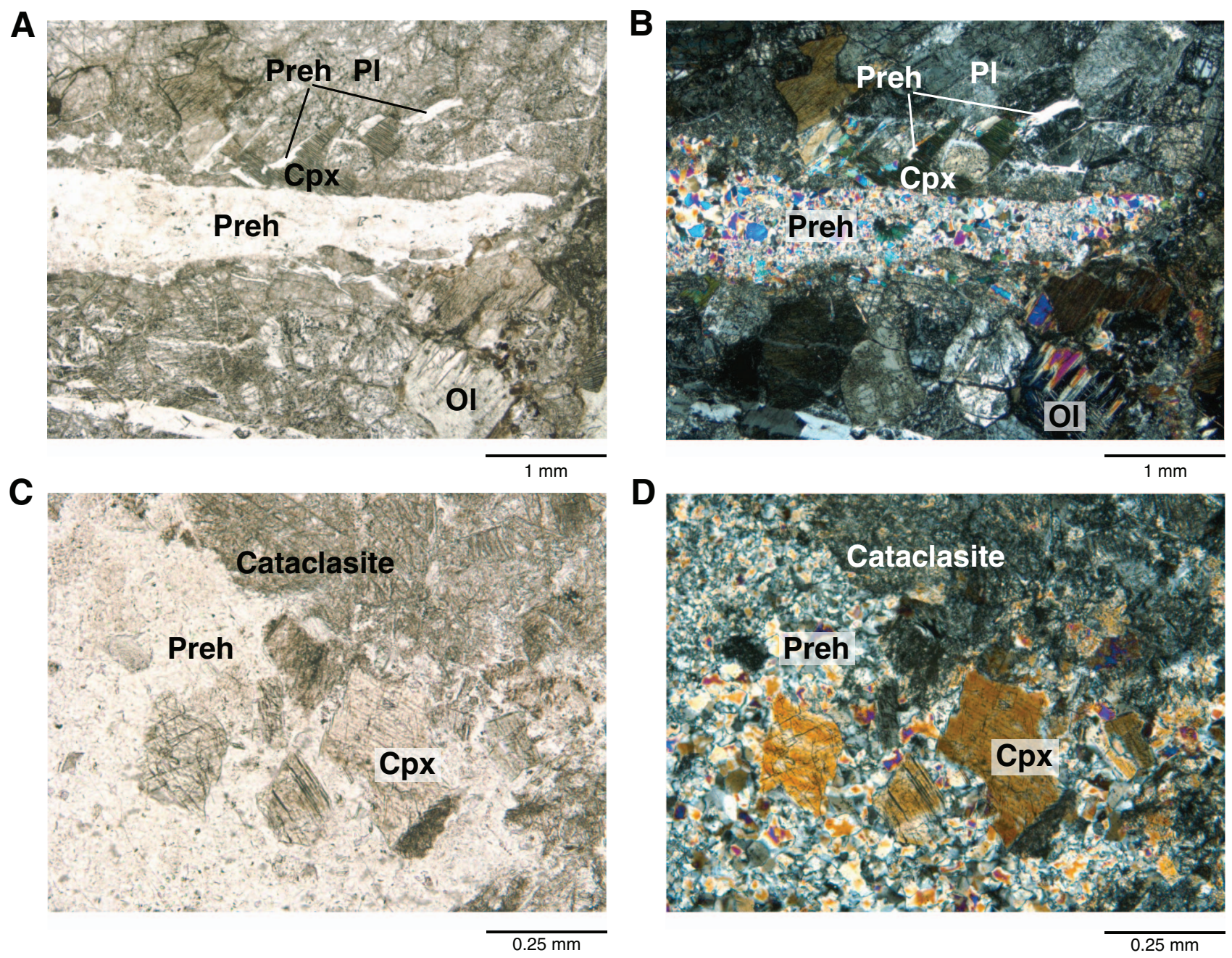

$0.25 \mathrm{~mm}$ 
Figure F15. Grain mount of cuttings from drilling-induced disaggregated gabbro (Thin Section 17; Sample 345U1415I-3R-3, 72-77 cm; under crossed polars). A. Whole thin section image. B. Cataclasite and a clast of prehnite (Preh), probably replacing plagioclase (Pl) in cataclasite. C. Development of a corona texture in olivine (Ol) adjacent to relatively fresh plagioclase. $\mathrm{Amph}=$ amphibole, $\mathrm{Chl}=$ chlorite, $\mathrm{Tc}=$ talc .

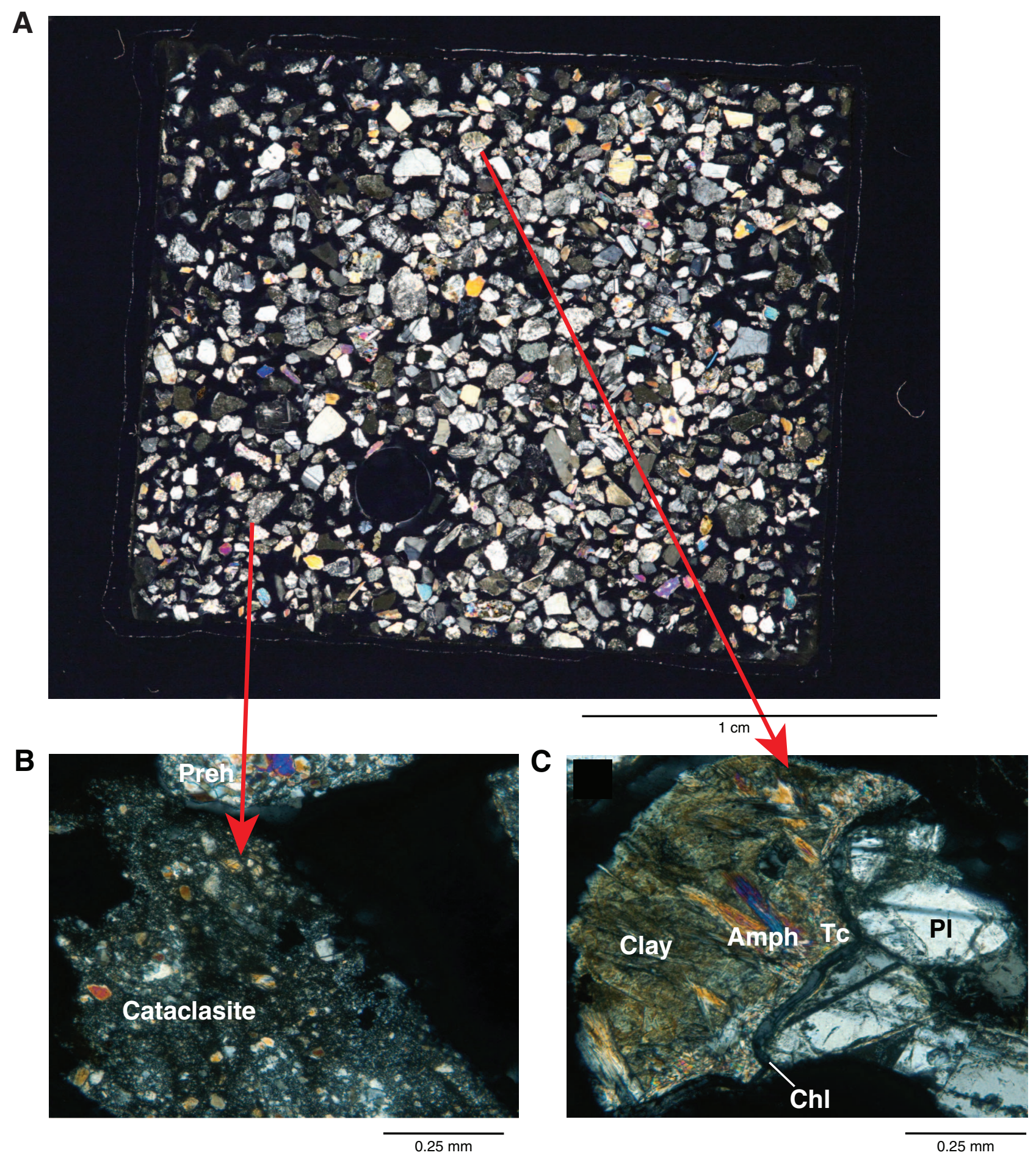


Figure F16. Vein-filling material composed of prehnite (confirmed by X-ray diffraction) (Sample 345-U14155G-1A, 9-12 cm [Piece 2]).

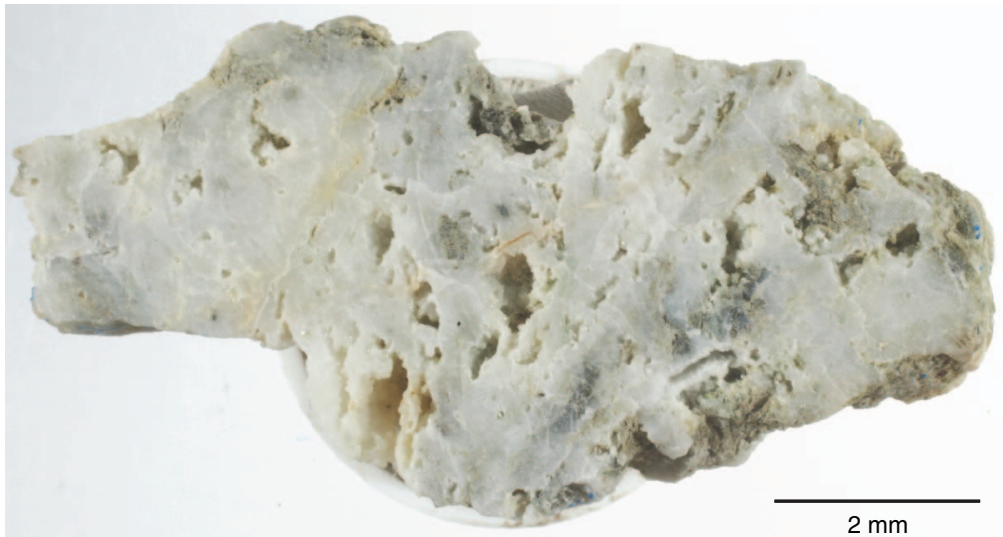


Figure F17. Location of magmatic layering within the core and measured dip of magmatic foliation, Hole U1415I. Std. dev. = standard deviation.

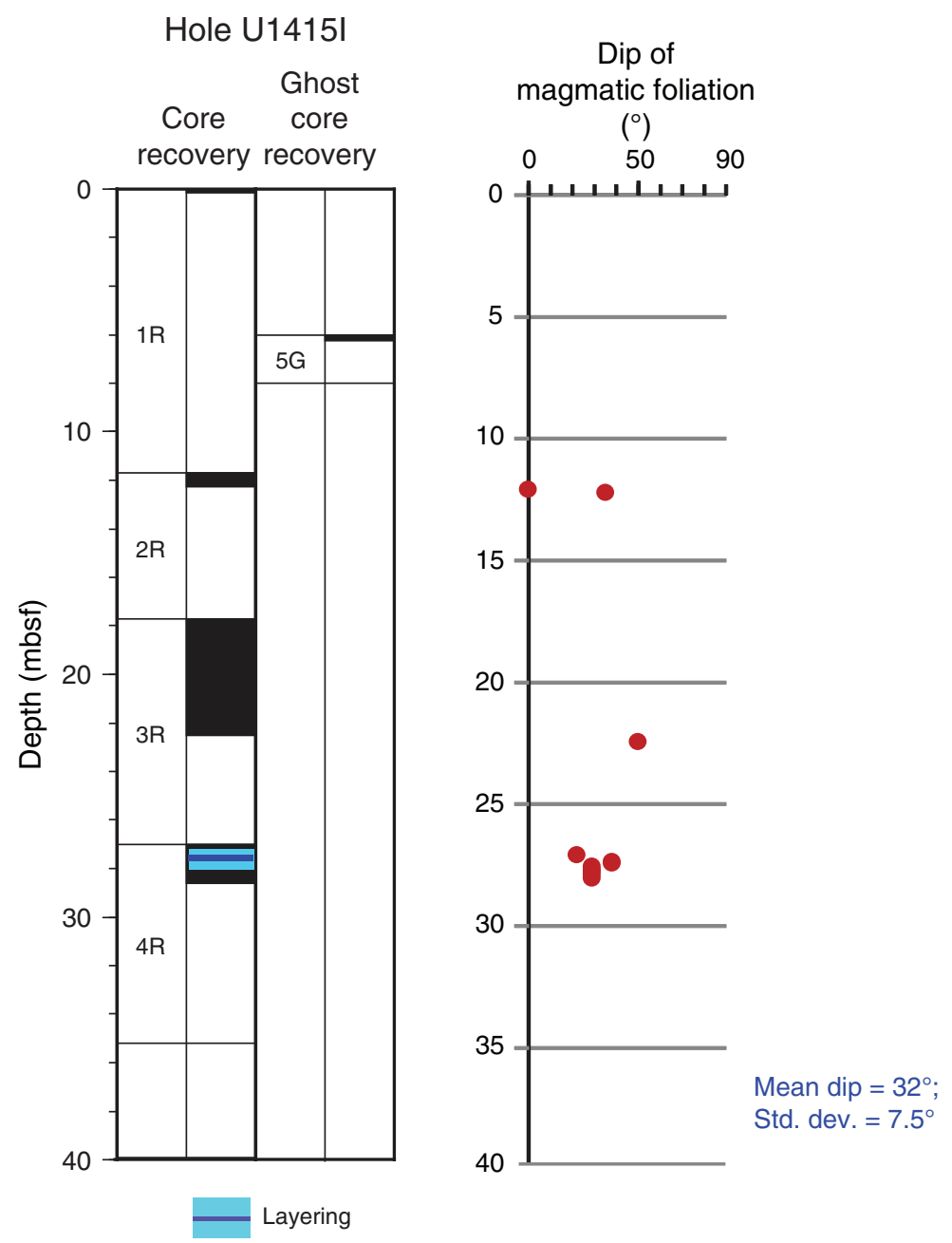


Figure F18. A. Centimeter-scale olivine-plagioclase modal layering and magmatic foliation (Sample 345U1415I-4R-1, 63-78 cm [Piece 8C]; wet image). B-E. Olivine gabbro with strong magmatic foliation defined by plagioclase, olivine, and clinopyroxene shape-preferred orientation (SPO; double red arrow in B) (Sample 345U1415I-4R-1, 35-38 cm [Piece 6]). (B) Plane-polarized light. (C) Strong magmatic foliation defined by plagioclase, olivine, and clinopyroxene SPO. Red boxes (tick mark shows upward direction) indicate the location of images in D and E; F lies outside the field of view shown in C. (D) Deformation twins and subgrain development in plagioclase. (E) Skeletal olivine. F. Olivine showing straight subgrain boundaries. C-F are under crossed polars.

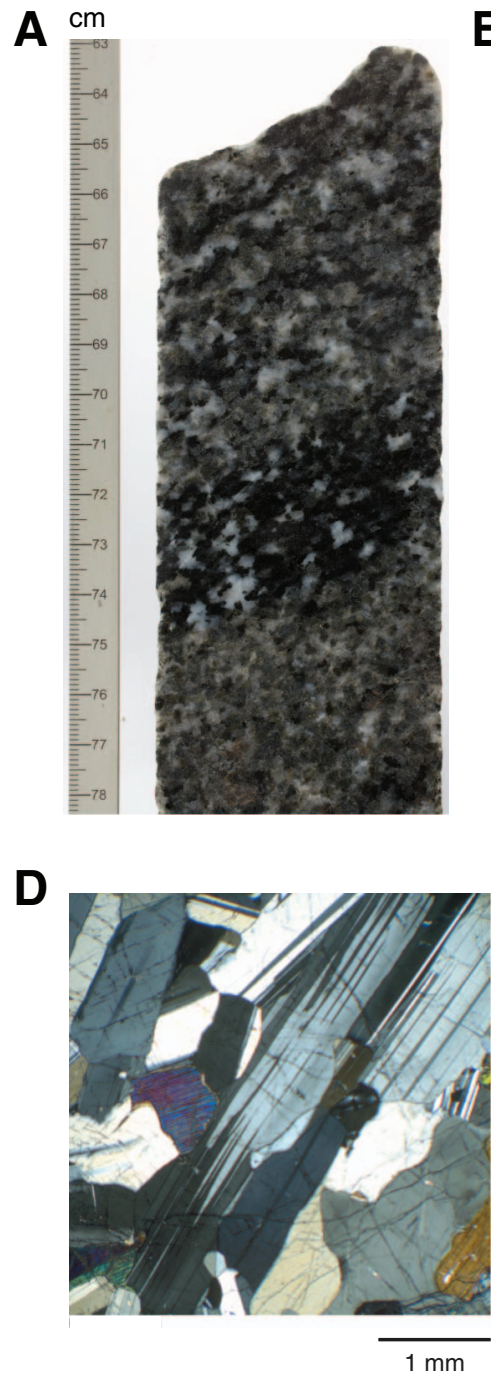

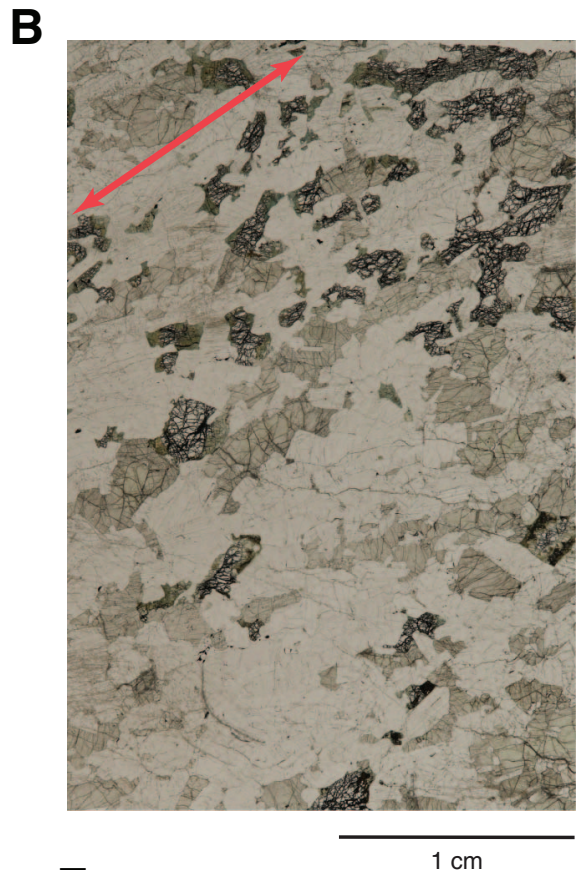

E

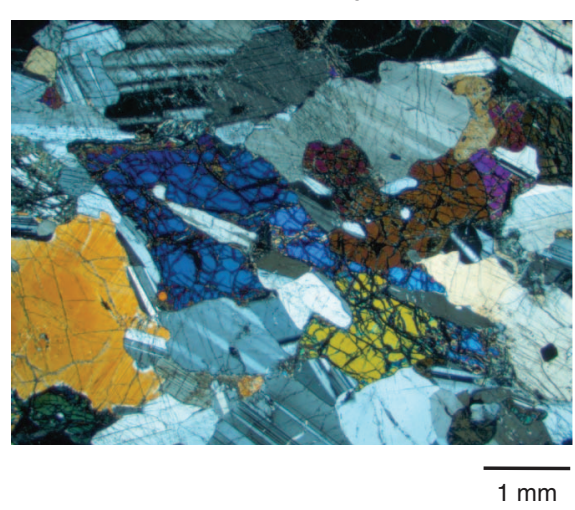

C

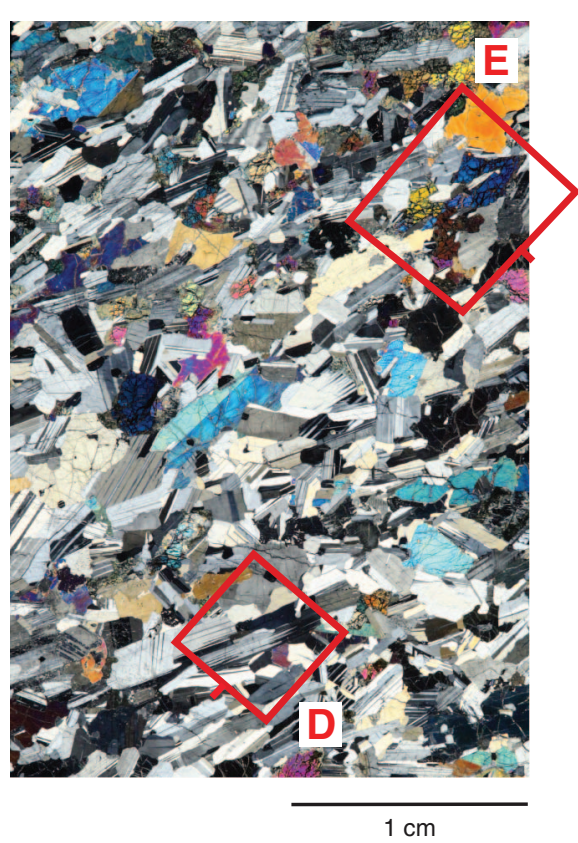

F

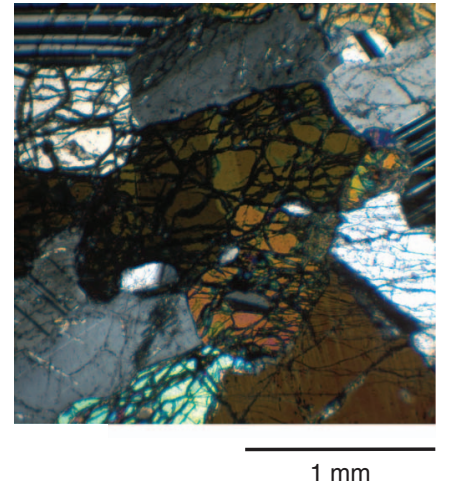


Figure F19. Magmatic foliation strength, Hole U1415I. A. Foliation strength expressed as percentage of core length. B. Foliation strength for three dominant rock types in the core. C. Olivine gabbro foliation strength expressed as percentage of core length.

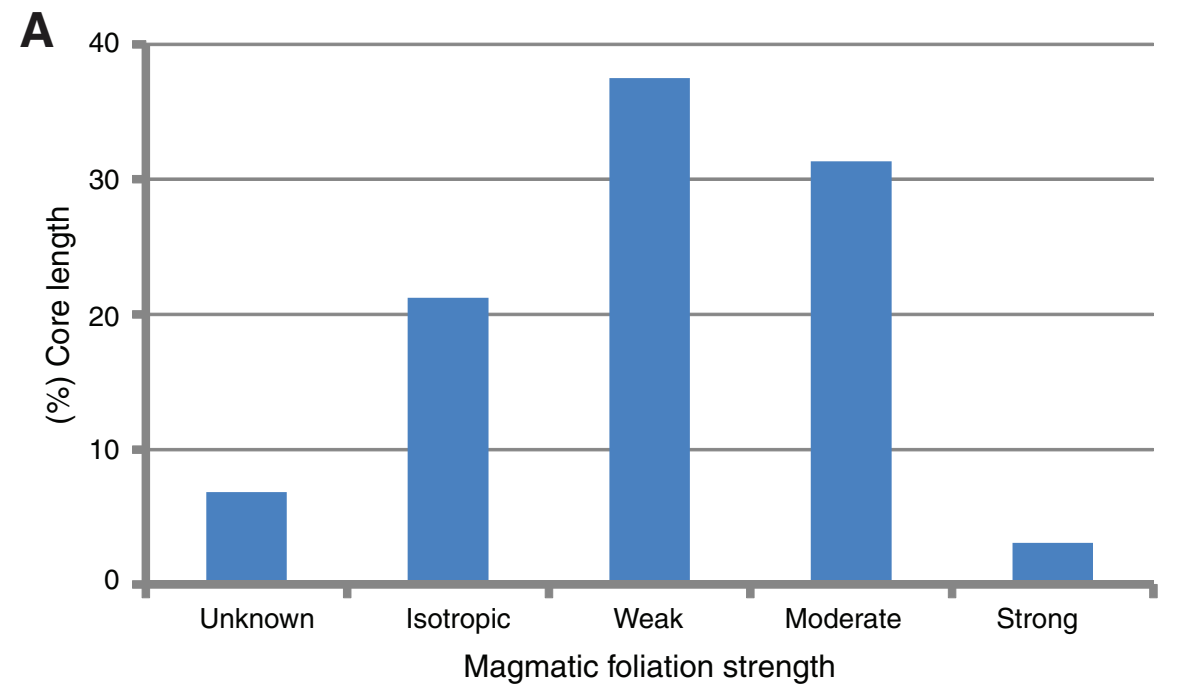

B

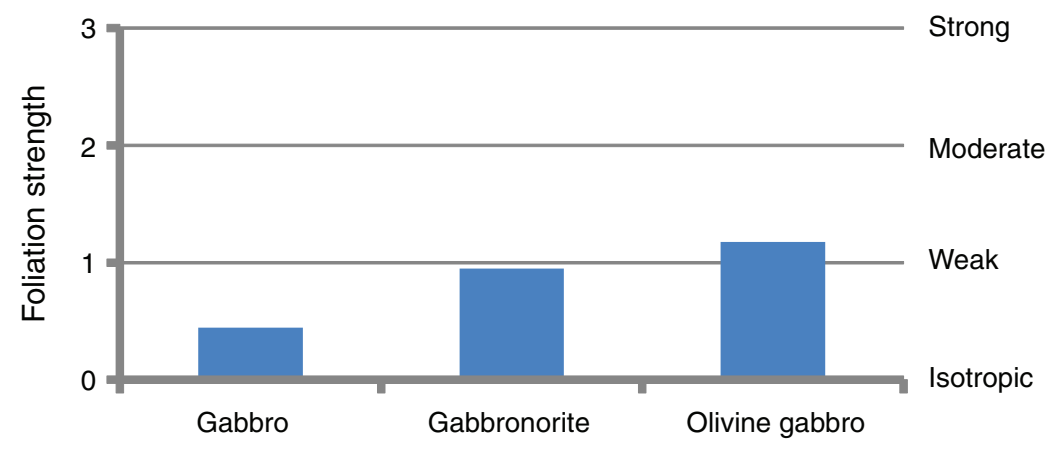

Rock type

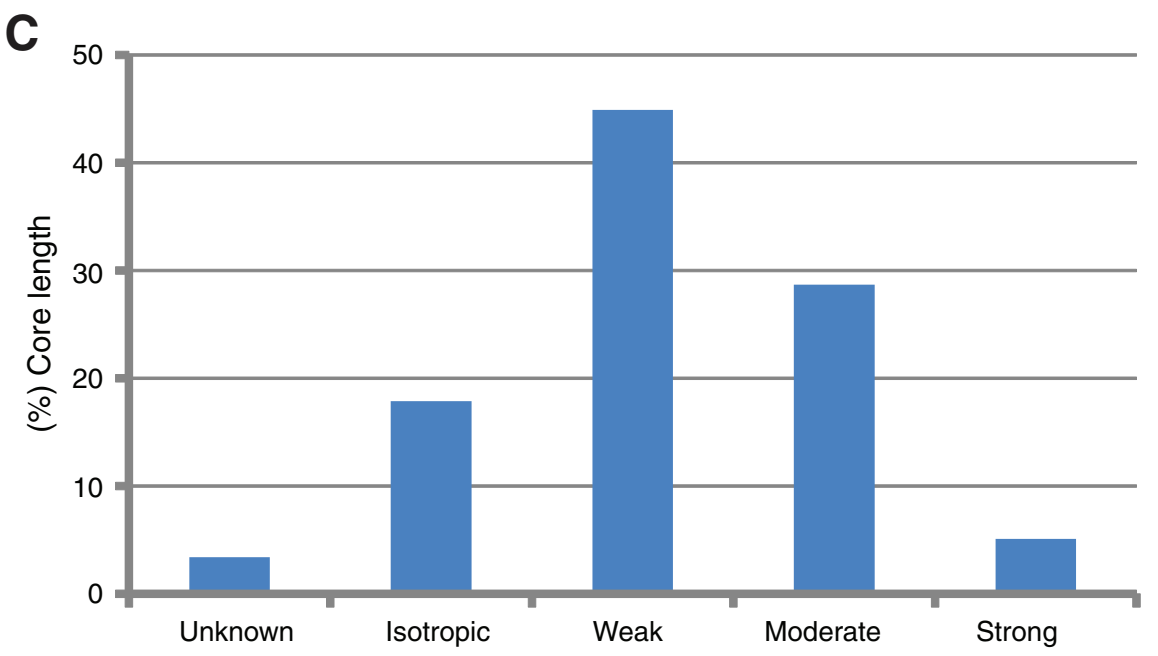

Olivine gabbro foliation strength 
Figure F20. Variation in magmatic foliation strength from strong to moderate, weak, and isotropic (under crossed polars). Red arrows $=$ orientation of foliation. A. Strong magmatic foliation in olivine gabbro defined by shape-preferred orientation (SPO) of plagioclase, olivine, and clinopyroxene (Sample 345-U1415I-4R-1, 35-38 cm [Piece 6]). B. Moderate magmatic foliation in olivine-bearing gabbronorite defined by SPO of plagioclase, olivine, and clinopyroxene (Sample 345-U1415I-4R-1, 48-50 cm [Piece 8A]). C. Weak magmatic foliation in gabbro defined by plagioclase SPO (Sample 345-U1415I-4R-1, 136-139 cm [Piece 12]). D. Isotropic magmatic foliation in olivine gabbro (Sample 345-U1415I-3R-4, 16-19 cm [Piece 2]).

A

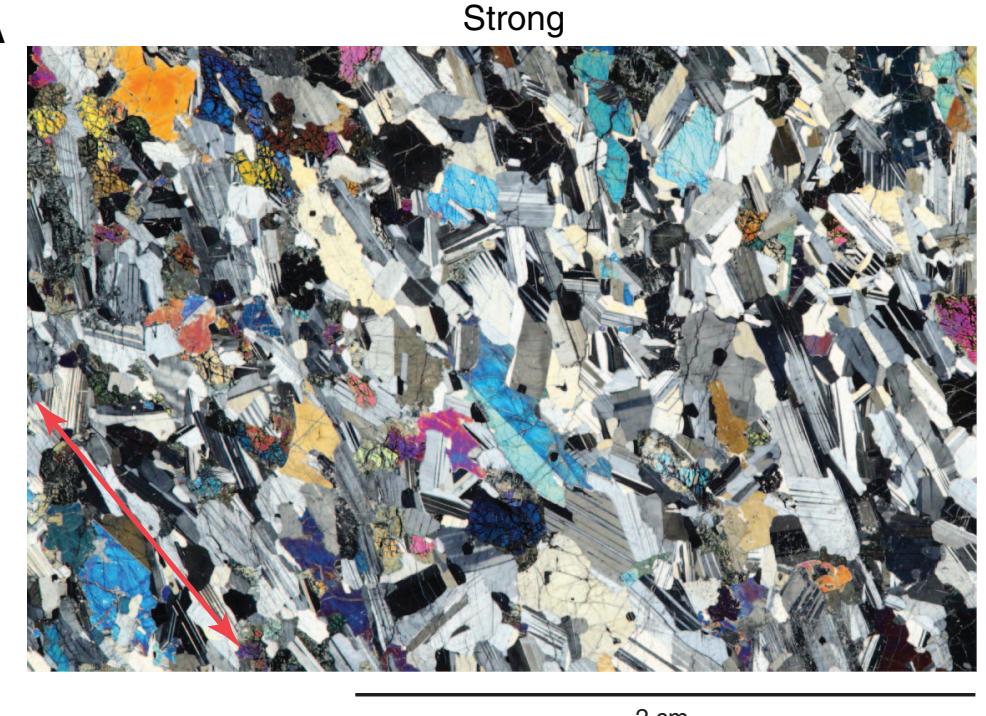

B

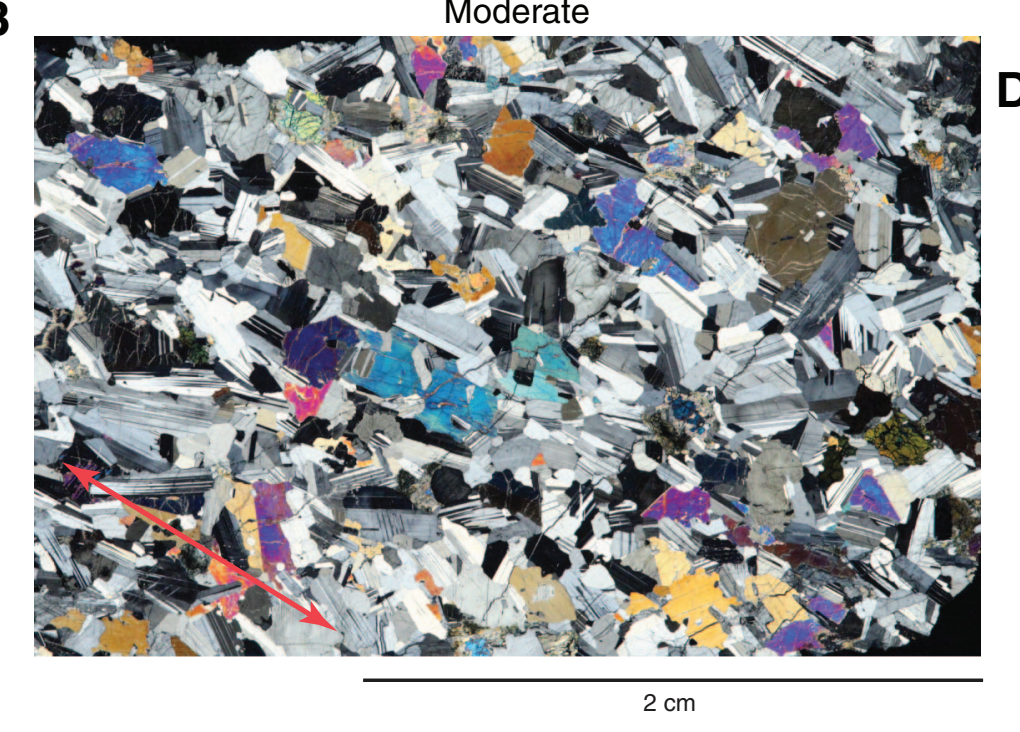

C

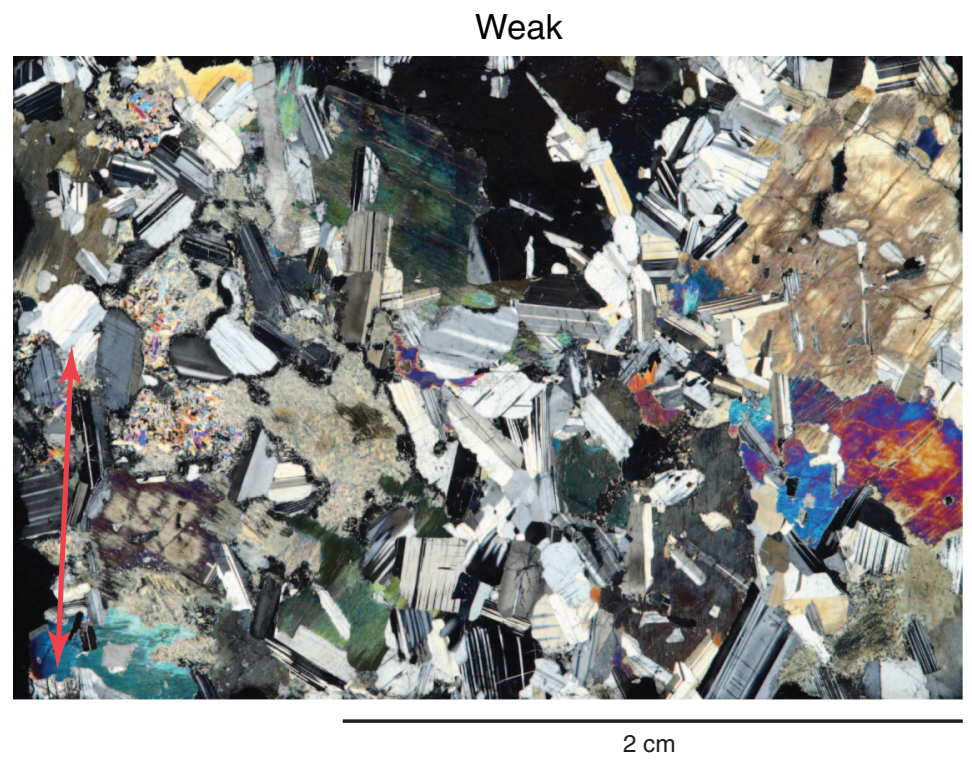

D

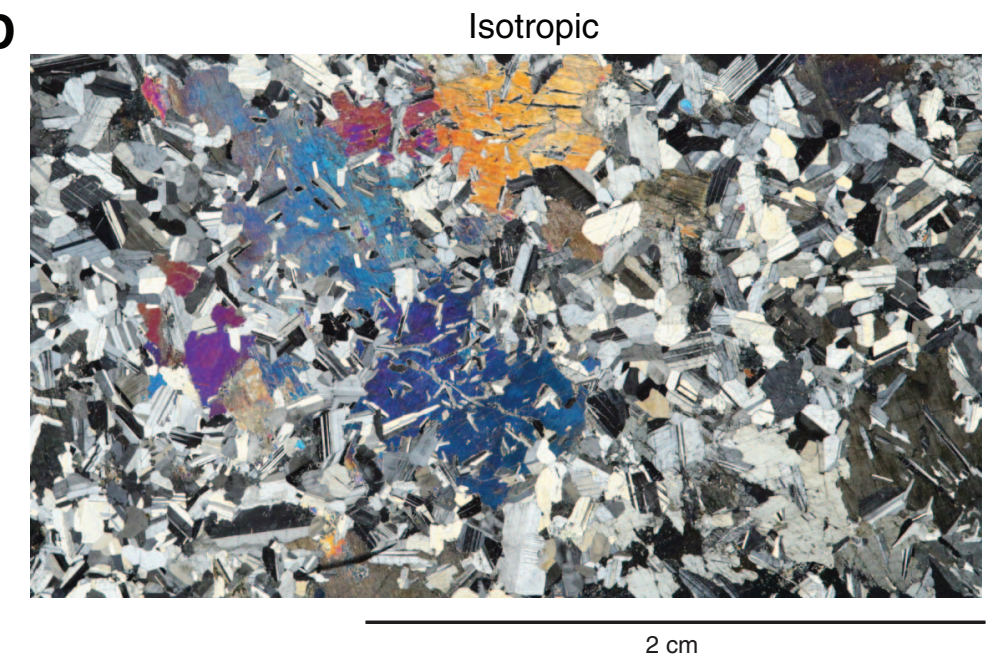


Figure F21. Clinopyroxene-bearing troctolite (Sample 345-U1415I-4R-2, 9-13 cm [Piece 2]; under crossed polars). A. Whole thin section image showing moderate-strength magmatic foliation defined by plagioclase and olivine shape-preferred orientation (SPO; red arrow) and one complete and one partial clinopyroxene oikocryst. Foliation wraps around the oikocrysts, which contain elongate, randomly oriented sparse plagioclase crystals. Red boxes (tick mark shows upward direction) indicate the location of images in B, C, D, and E. B. Magmatic foliation in troctolite showing elongated skeletal olivine between annealed plagioclase crystals. C. Olivine subgrains with straight grain boundaries and plagioclase deformation twins within the magmatic foliation. D. Detail of magmatic foliation wrapping around the margin of a clinopyroxene oikocryst and included plagioclase crystals within the oikocryst. E. Bent plagioclase crystal within the margin of the clinopyroxene oikocryst. Other plagioclase crystals at the boundary of the oikocryst show deformation twins.

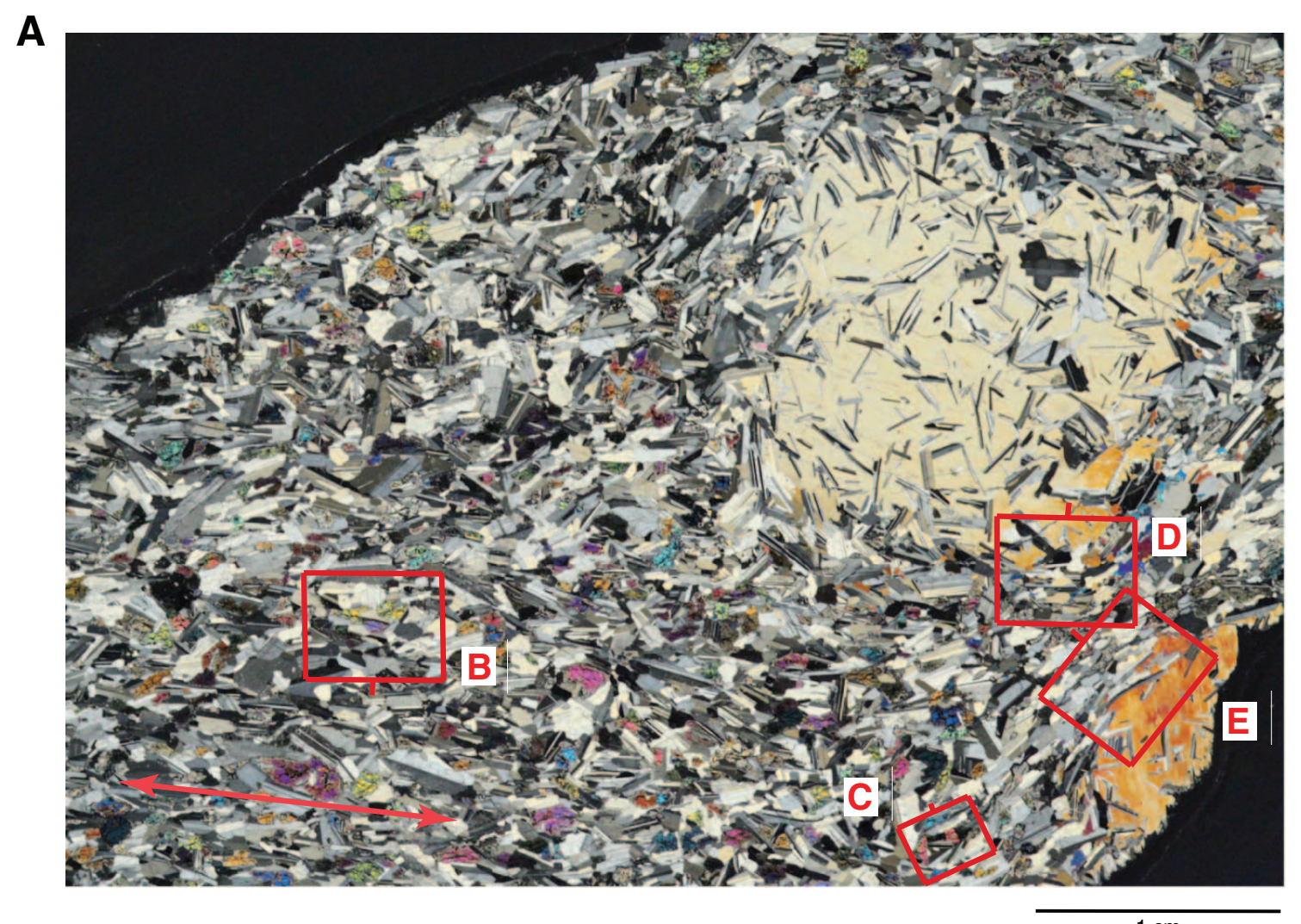

B

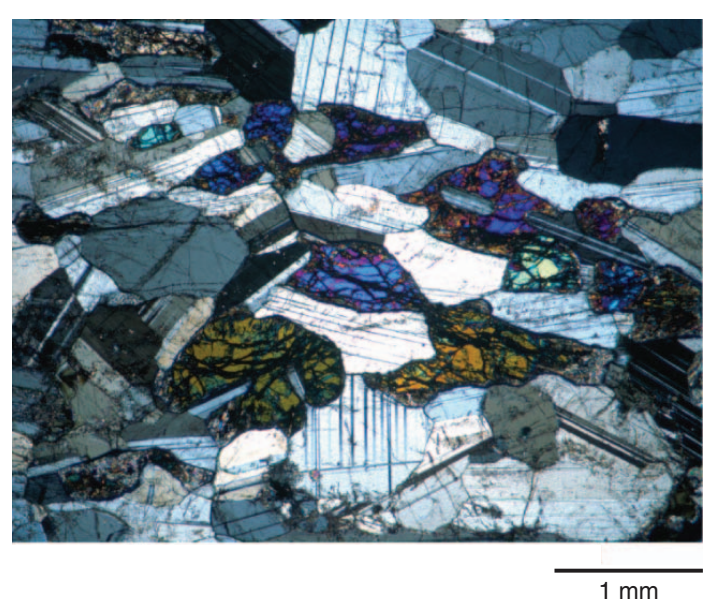

D

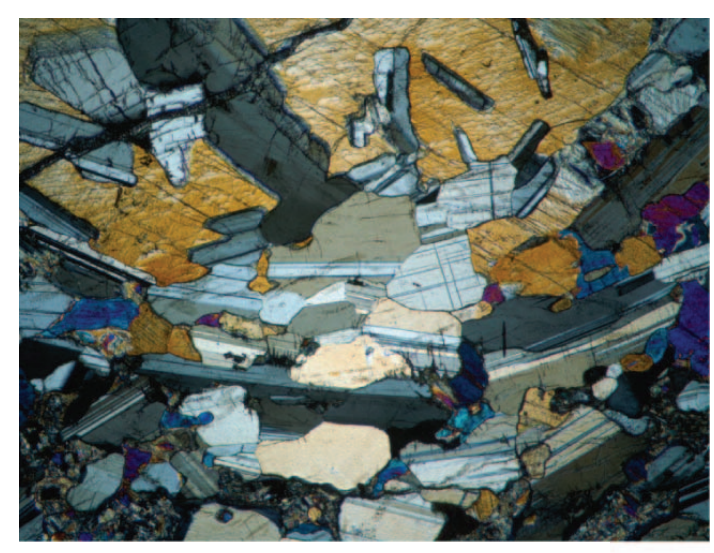

C

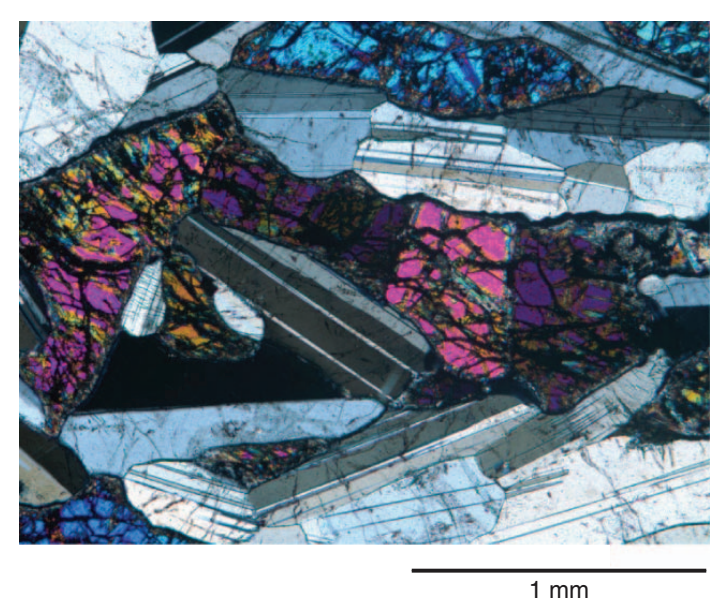

E

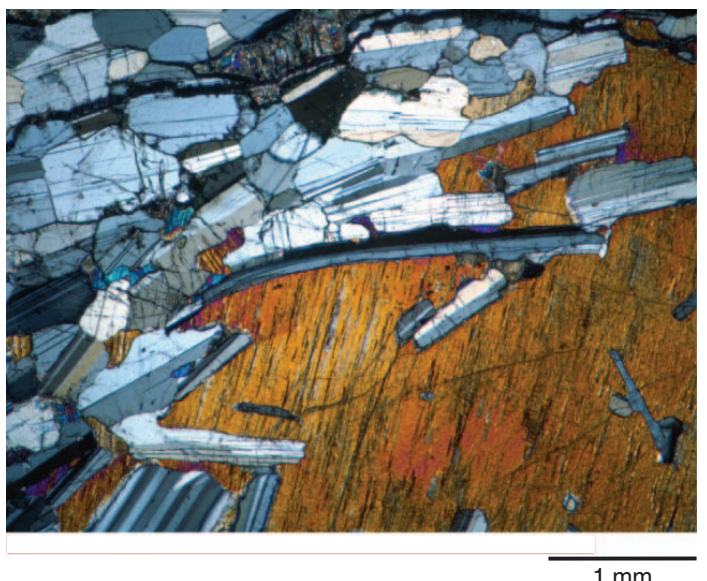


Figure F22. Magmatic textures (under crossed polars). A. Olivine gabbro showing deformation twins in a relatively large and only weakly annealed, zoned plagioclase crystal (Sample 345-U1415I-3R-4, 16-19 cm [Piece 2]). B. Gabbro showing a highly deformed plagioclase crystal with undulose extinction (Sample 345-U1415I4R-1, 136-139 cm [Piece 12]). C. Gabbronorite with plagioclase crystals showing annealed grain boundaries with $120^{\circ}$ triple junctions (Sample 345-U1415I-4R-1, 48-50 cm [Piece 8A]). D. Olivine gabbro with plagioclase crystals showing annealed grain boundaries and deformation twins (Sample 345-U1415I-2R-1, 2-6 cm [Piece 1]). E. Olivine gabbro with plagioclase crystals showing subgrains (Sample 345-U1415I-1R-1, 1-4 cm [Piece 1]) F. Gabbronorite showing irregular, bulging grain boundaries between plagioclase crystals and clinopyroxene, suggesting grain boundary migration and dissolution (Sample 345-U1415I-5G-1, 12-14 cm [Piece 3]).

A

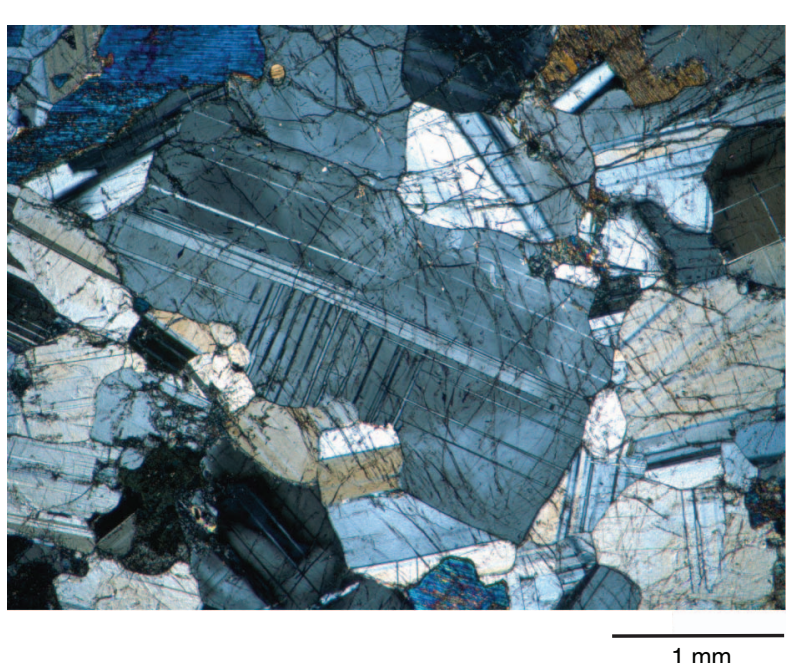

C

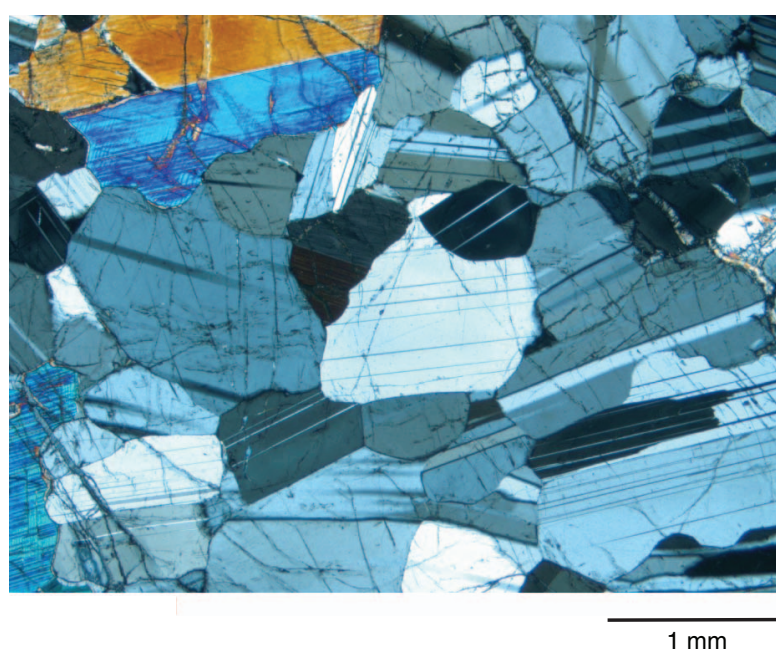

E

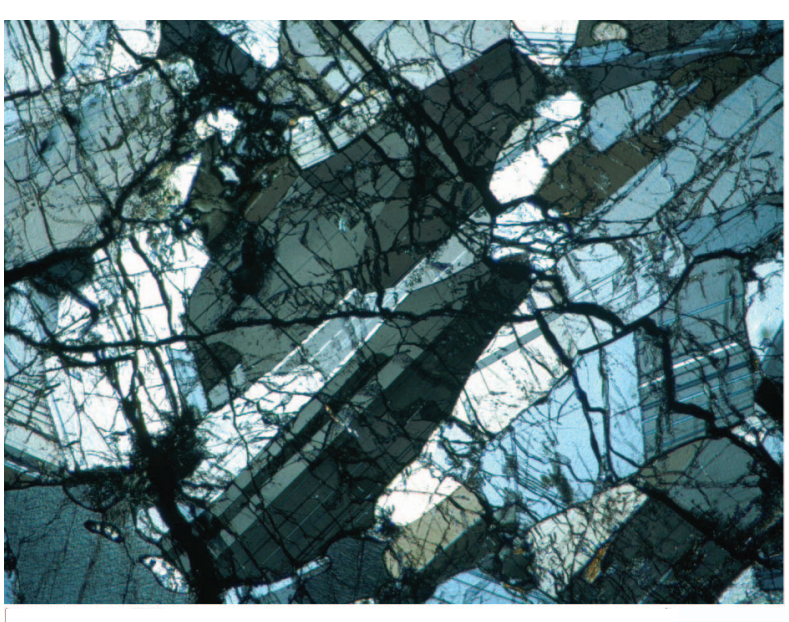

B

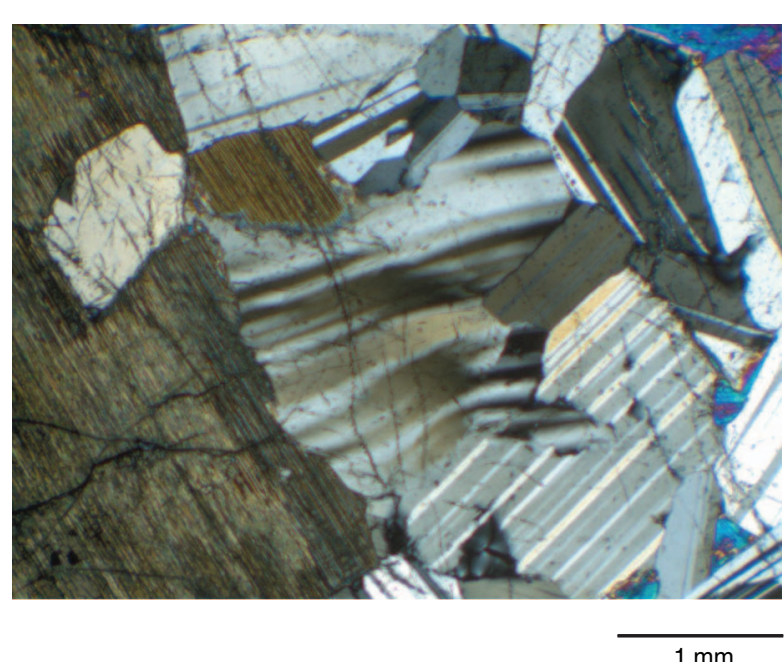

D

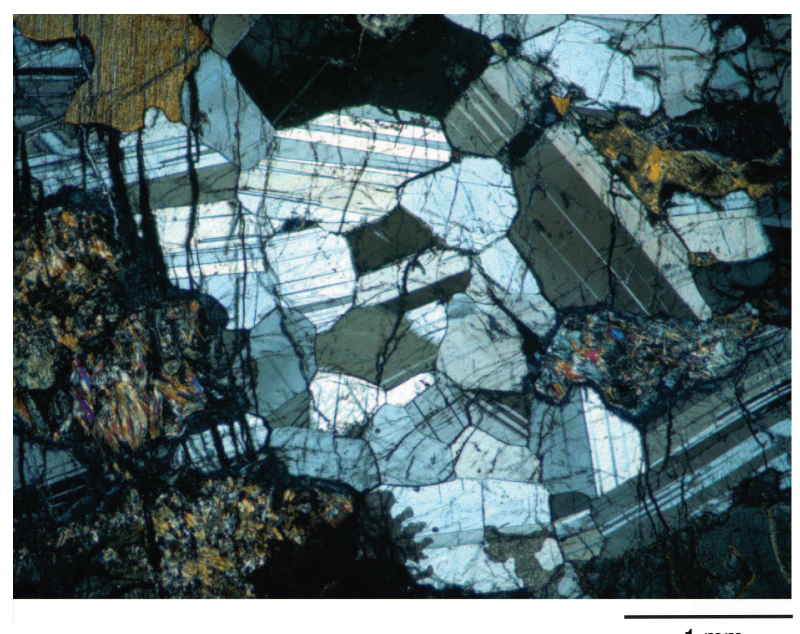

$\mathbf{F}$

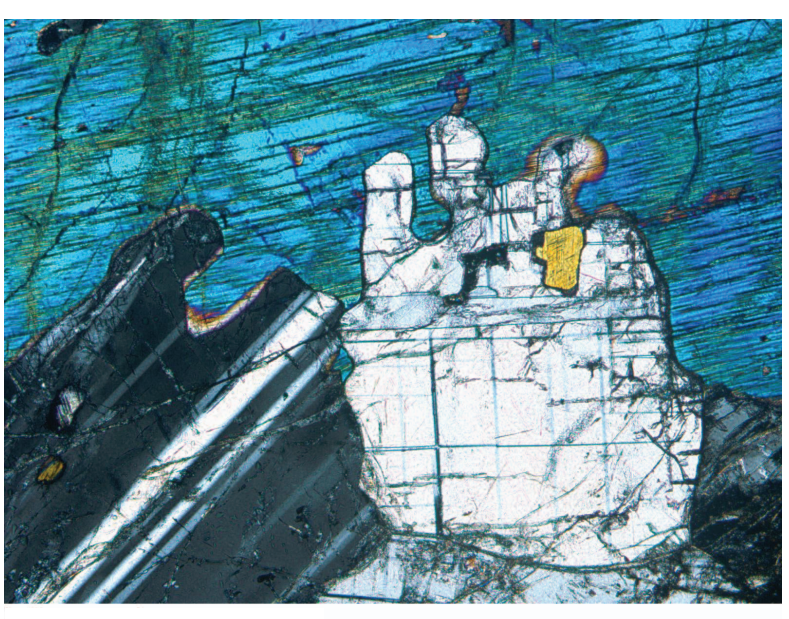

$1 \mathrm{~mm}$

$1 \mathrm{~mm}$ 
Figure F23. Macroscopic brittle structures. A. Thin zone of cataclasis cutting olivine gabbro (lower right) (Sample 345-U1415I-2R-1, 31.5-35 cm [Piece 8]; unoriented). B. Thin zone of subvertical cataclasis cutting olivine gabbro (Sample 345-U1415I-2R-1, 24.5-31 cm [Piece 7]).

A

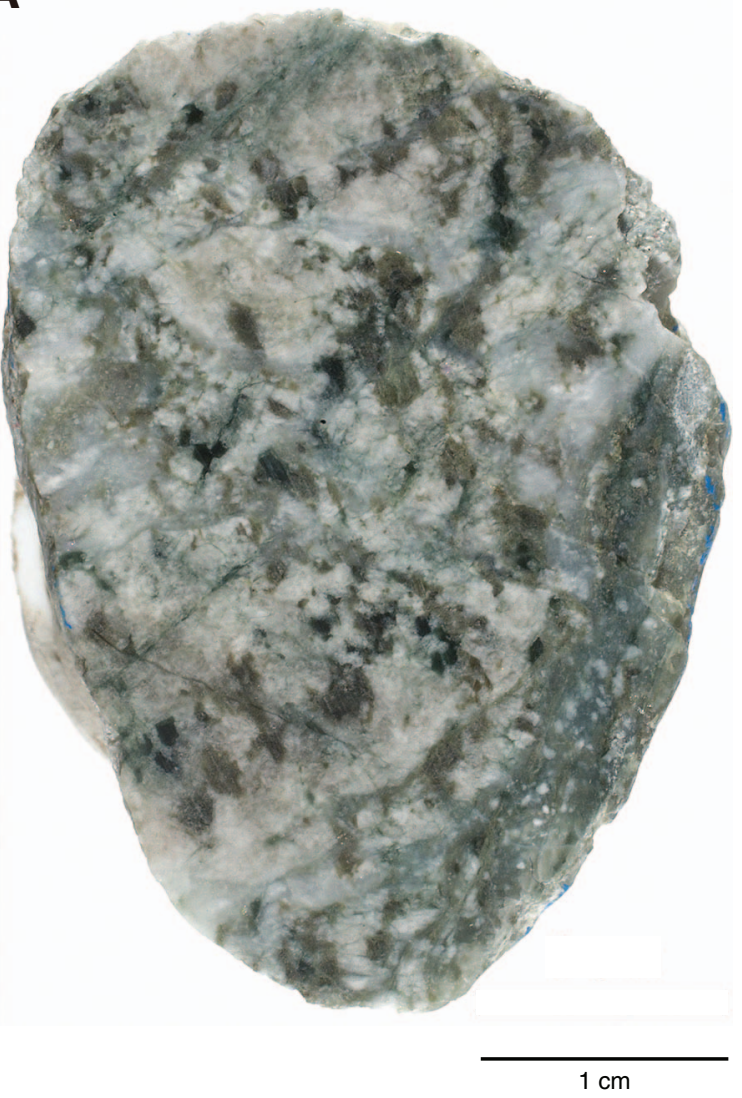

B

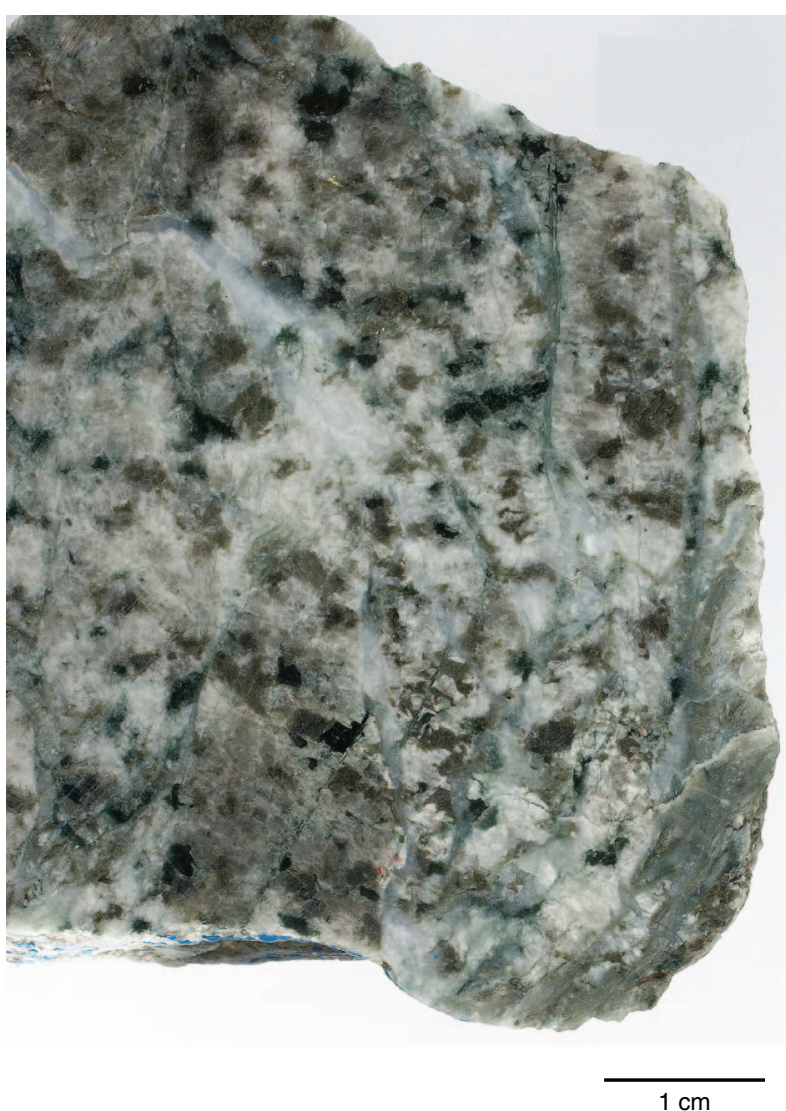


Figure F24. Microscopic cataclastic deformation structures. A. Cataclastic deformation in olivine-bearing gabbro showing grain size reduction, grain rotation, and angular-shaped clasts hosted in a fine clay(?)-rich matrix (Thin Section 20; Sample 345-U1415I-4R-2, 15-17 cm [Piece 3]; plane-polarized light). B, C. Thin Section 13 (Sample 345-U1415I-2R-1, 25-31 cm [Piece 7]; under crossed polars). B. Cataclastic deformation cutting host and a prehnite vein. C. Undeformed prehnite vein cutting a zone of cataclasis.
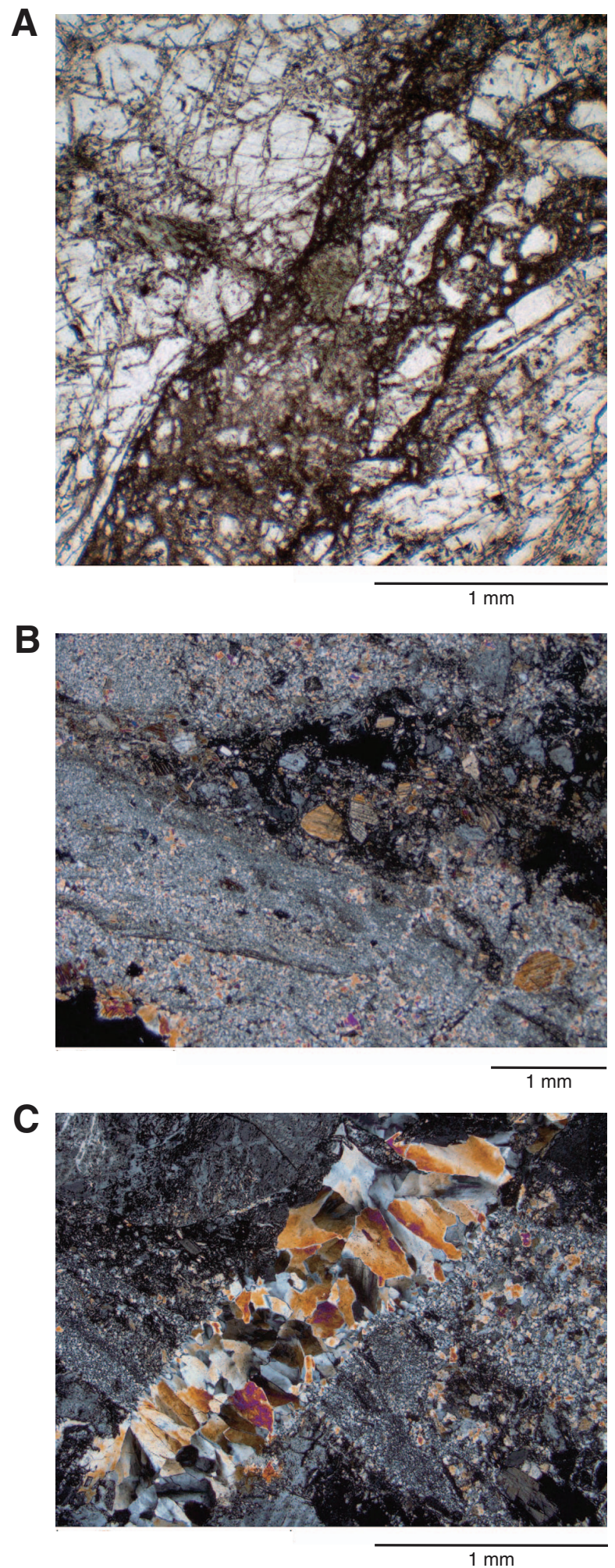
Figure F25. Variation in modal olivine percentage, low-field magnetic susceptibility (measured on the Section Half Multisensor Logger point susceptibility system), and natural remanent magnetization (NRM) intensity (measured on the superconducting rock magnetometer), Section 345-U1415I-4R-1A.

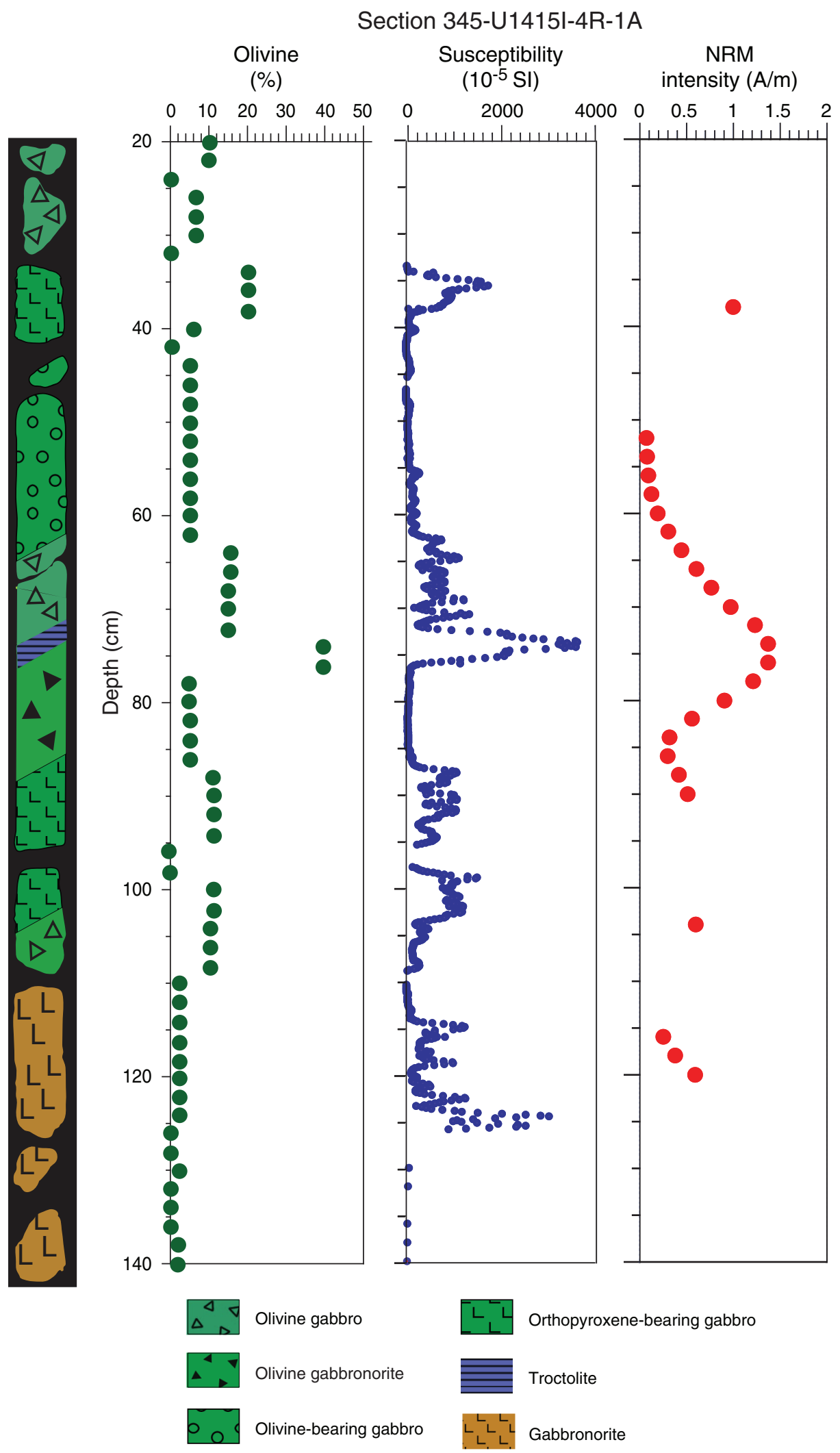


Figure F26. A-E. Representative examples of alternating field demagnetization of archive-half core pieces, Hole U1415I. Note that with the exception of Sample 345-U1415I-2R-1A, $52 \mathrm{~cm}$, which shows a single well-defined remanence component, all samples are affected by acquisition of a spurious anhysteretic remanent magnetization (ARM; red arrows) at higher demagnetizing fields. Right plots are details from circled areas in the left plots. Solid circles $=$ projection onto the horizontal plane, open circles $=$ projection onto the vertical $x-z$ plane. $\mathrm{NRM}=$ natural remanent magnetization .

A U1415I-2R-1A, $52 \mathrm{~cm}$ Orthopyroxene-bearing olivine gabbro $\mathrm{NRM}=112.7 \mathrm{~mA} / \mathrm{m}$

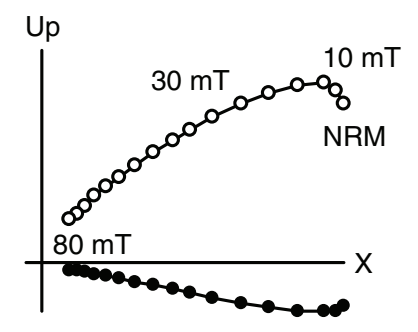

B U1415I-4R-1A, $62 \mathrm{~cm}$ Olivine-bearing gabbronorite $\mathrm{NRM}=307.0 \mathrm{~mA} / \mathrm{m}$

U1415I-4R-1A, $72 \mathrm{~cm}$ Olivine gabbro $\mathrm{NRM}=1230.0 \mathrm{~mA} / \mathrm{m}$

E U1415I-4R-1A, $74 \mathrm{~cm}$ Troctolite $\mathrm{NRM}=905.0 \mathrm{~mA} / \mathrm{m}$
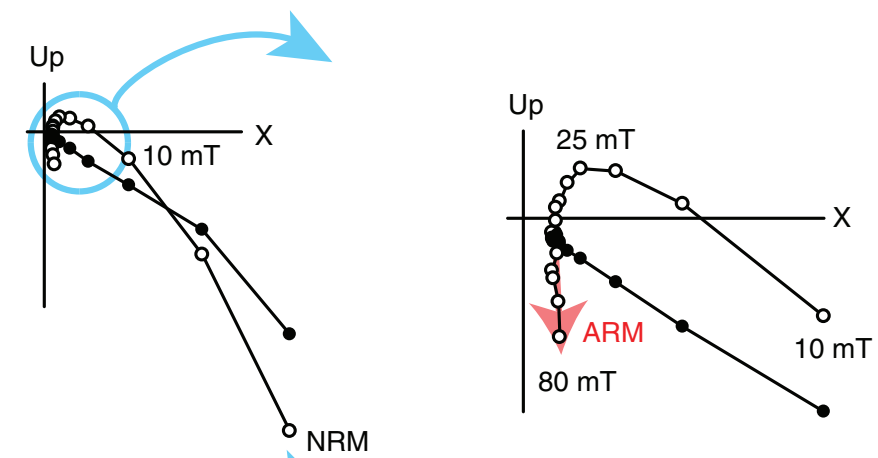

U1415I-4R-1A, $90 \mathrm{~cm}$ Orthopyroxene-bearing olivine gabbro $\mathrm{NRM}=512.0 \mathrm{~mA} / \mathrm{m}$
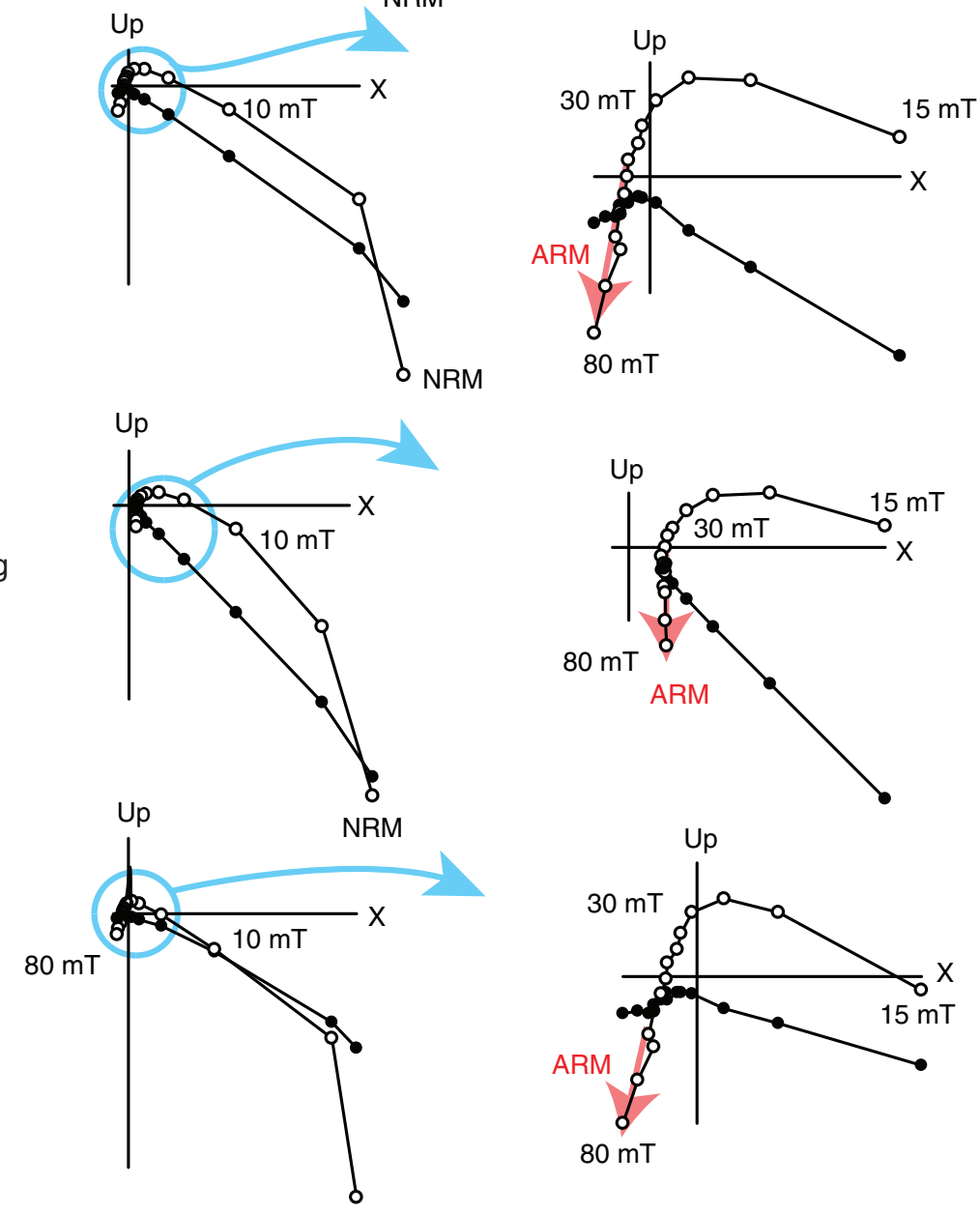
Figure F27. A-C. Demagnetization data from discrete samples from working-half core sections, Hole U1415I. Data were measured using the AGICO JR-6A spinner magnetometer and demagnetized using the DTech D-2000 system. Solid circles = projection onto the horizontal plane, open circles $=$ projection onto either the vertical $x-z$ or $y-z$ planes. NRM $=$ natural remanent magnetization.

A $\quad$ U1415l-2R-1W, $52 \mathrm{~cm}$ $\mathrm{NRM}=113.0 \mathrm{~mA} / \mathrm{m}$

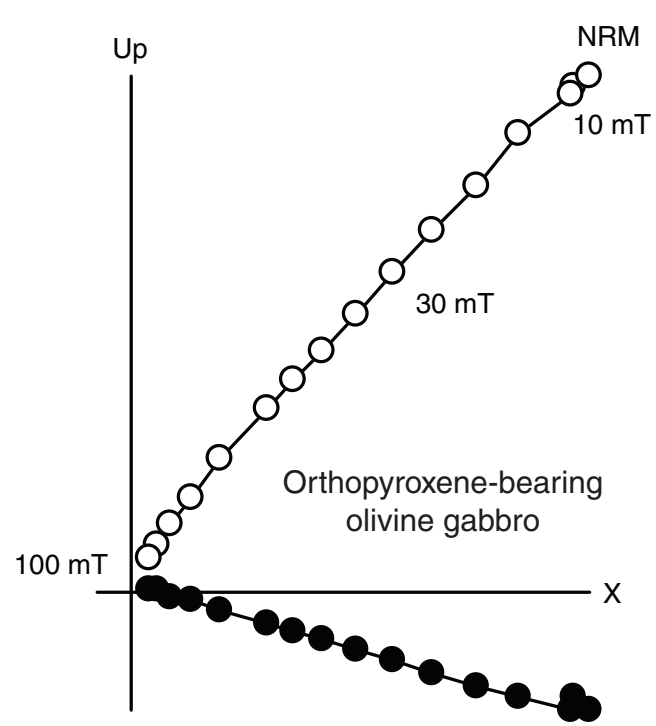

B U1415l-4R-1W, $51 \mathrm{~cm}$ $\mathrm{NRM}=23.9 \mathrm{~mA} / \mathrm{m}$

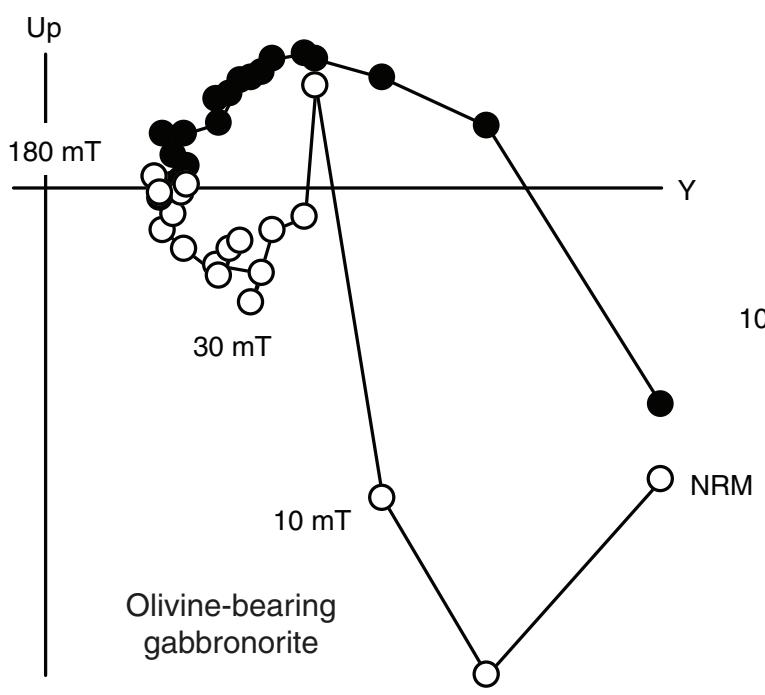

C U1415I-4R-1W, $113 \mathrm{~cm}$ $\mathrm{NRM}=62.9 \mathrm{~mA} / \mathrm{m}$

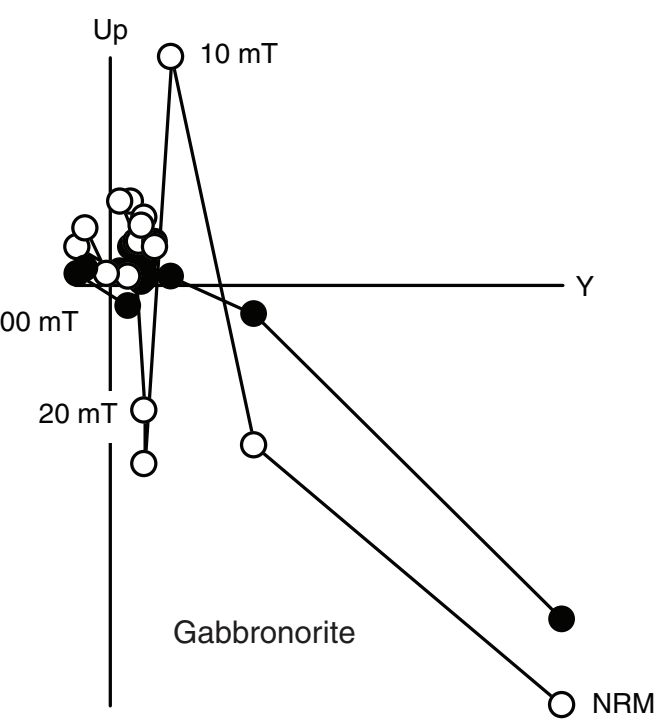


Figure F28. A-C. Anisotropy of low-field magnetic susceptibility data from three discrete samples in Hole U1415I. Projections show statistically distinct bootstrapped mean eigenvectors averaged from three measurements of each discrete sample. Red, green, and blue lines represent 95\% bootstrapped confidence ellipses associated with the maximum, intermediate, and minimum eigenvectors, respectively. Great circles indicate the orientation of magmatic foliations determined from structural observations in the core.

A

U1415l-2R-1W, $52 \mathrm{~cm}$

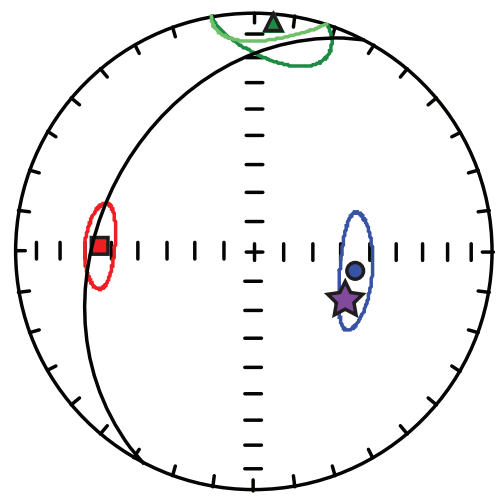

B

U1415I-4R-1W $51 \mathrm{~cm}$

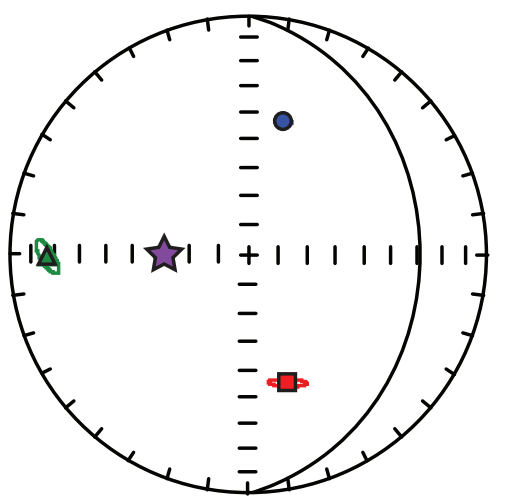

$k_{\max }$

$\Delta k_{\text {int }} \bigcirc k_{\text {min }}$

Magmatic foliation pole
C U1415I-4R-1W, $113 \mathrm{~cm}$

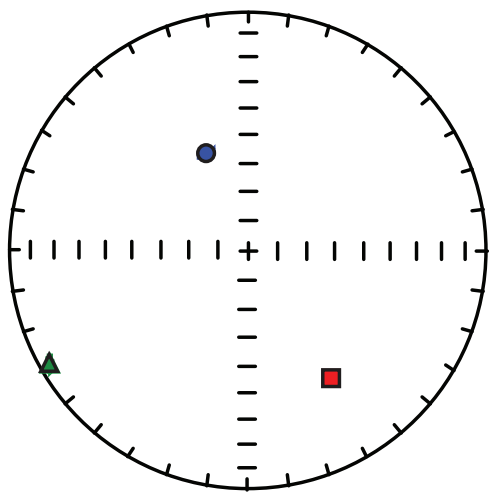


Figure F29. Variations of the measured loss on ignition (LOI) contents vs. (A) $\mathrm{CO}_{2}$ and $(\mathbf{B}) \mathrm{H}_{2} \mathrm{O}$. No correlation between LOI and $\mathrm{CO}_{2}$ can be seen for the studied rocks. A positive correlation can be observed between the LOI composition and the $\mathrm{H}_{2} \mathrm{O}$ content.

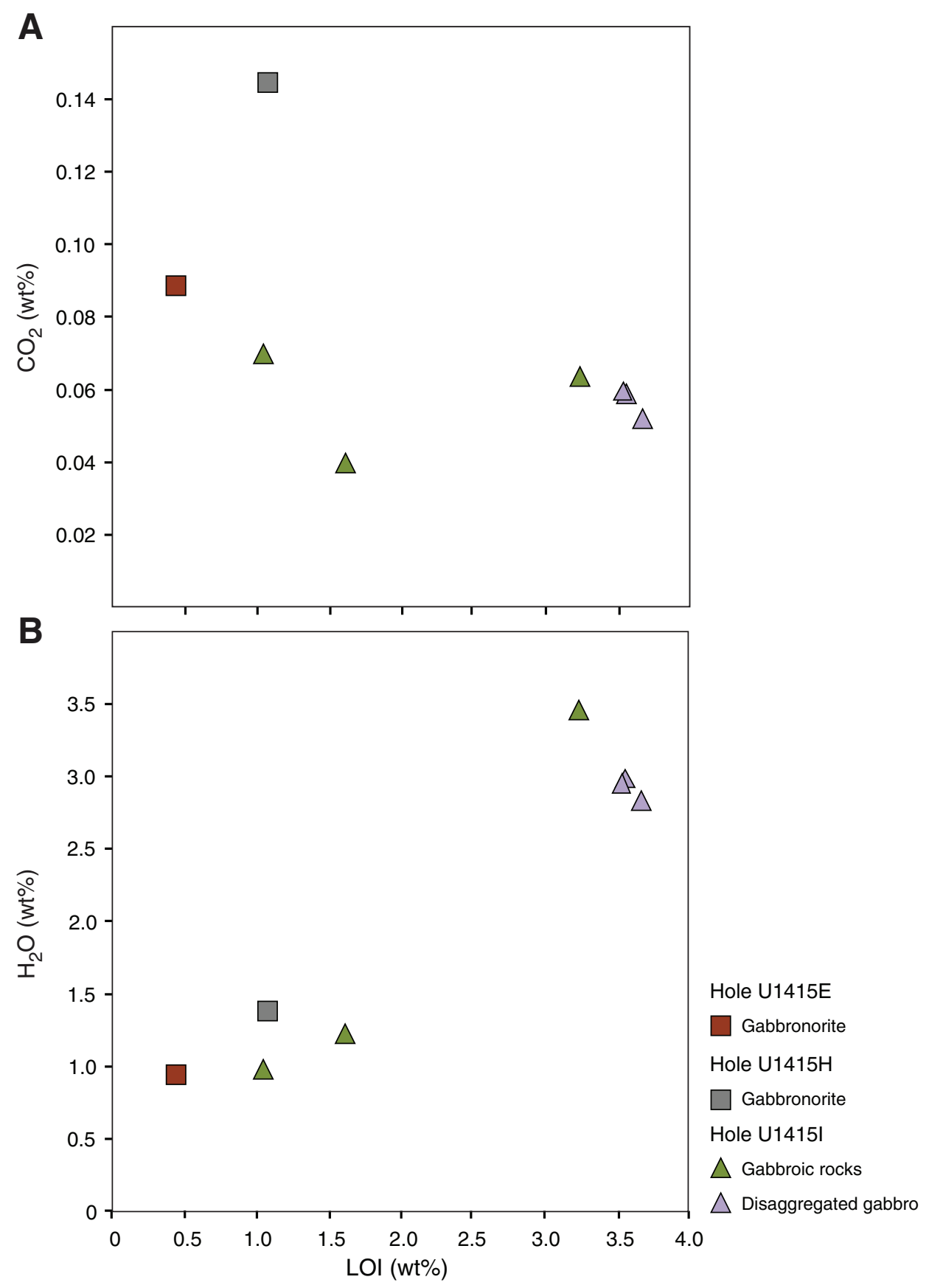


Figure F30. Bulk rock major element systematics in Hole U1415I illustrated on $(\mathrm{A}) \mathrm{Al}_{2} \mathrm{O}_{3},(\mathbf{B}) \mathrm{CaO},(\mathrm{C}) \mathrm{SiO}_{2}$, (D) $\mathrm{TiO}_{2}$, (E) $\mathrm{Zn}$, and (F) Sr vs. $\mathrm{Mg \#} \mathrm{(cationic} \mathrm{Mg} /[\mathrm{Mg}+\mathrm{Fe}]$ with all Fe as $\mathrm{Fe}^{2+}$ ) diagrams. For comparison, a compilation of the plutonic rock sampled along the East Pacific Rise at Hess Deep (Shipboard Scientific Party, 1993; Miller et al., 1996; Natland and Dick, 2009; Pedersen et al., 1996; Hanna, 2004; Kirchner and Gillis, 2012) and Pito Deep (Perk et al., 2007) is shown.
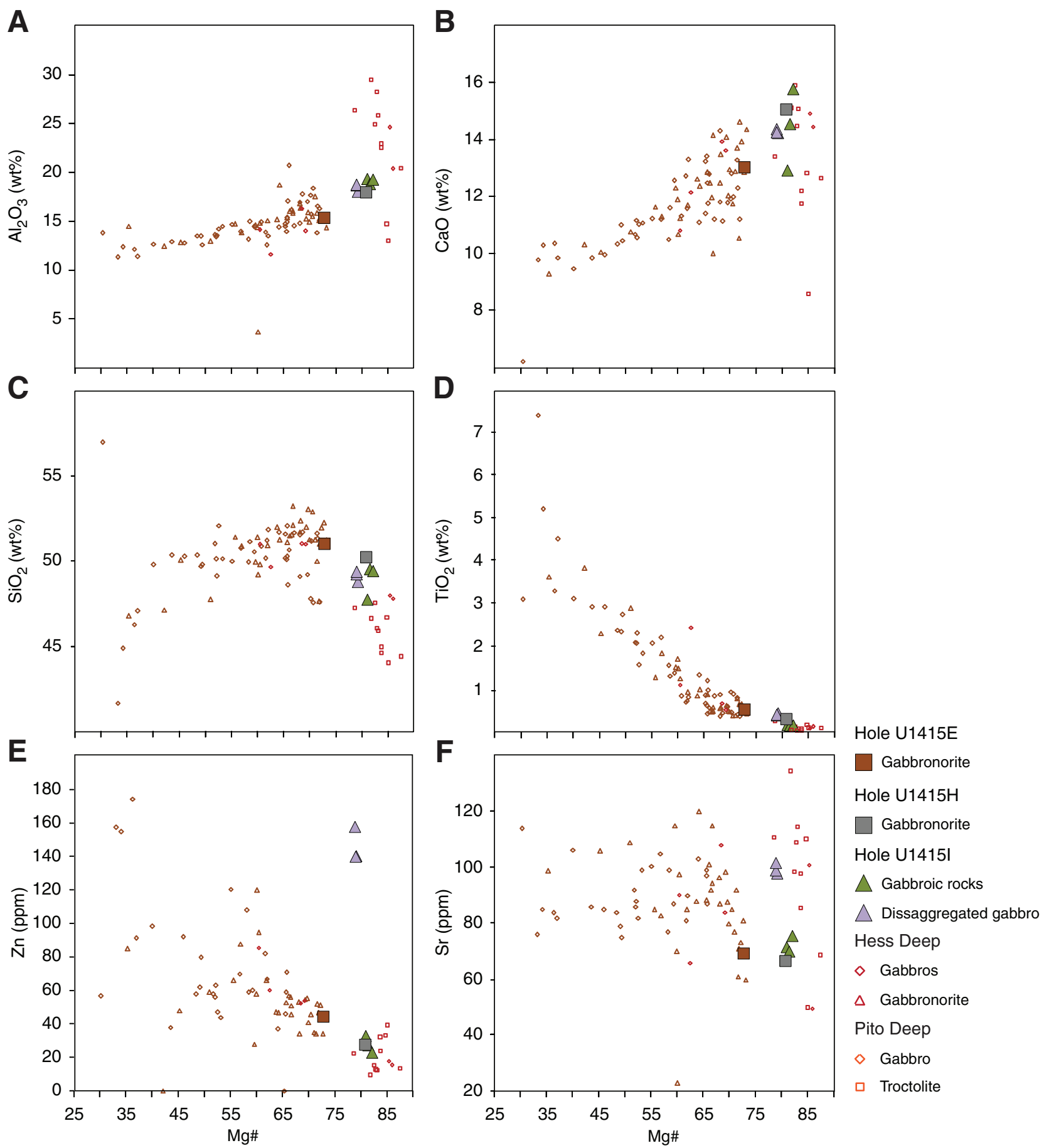
Figure F31. Summary of physical property measurements, Hole U1415I. Plotted gamma ray attenuation (GRA), Whole-Round Multisensor Logger (WRMSL), and Section Half Multisensor Logger (SHMSL) data are filtered (see "Physical properties" in the "Methods" chapter [Gillis et al., 2014e]). NGR = natural gamma radiation, MS = magnetic susceptibility.

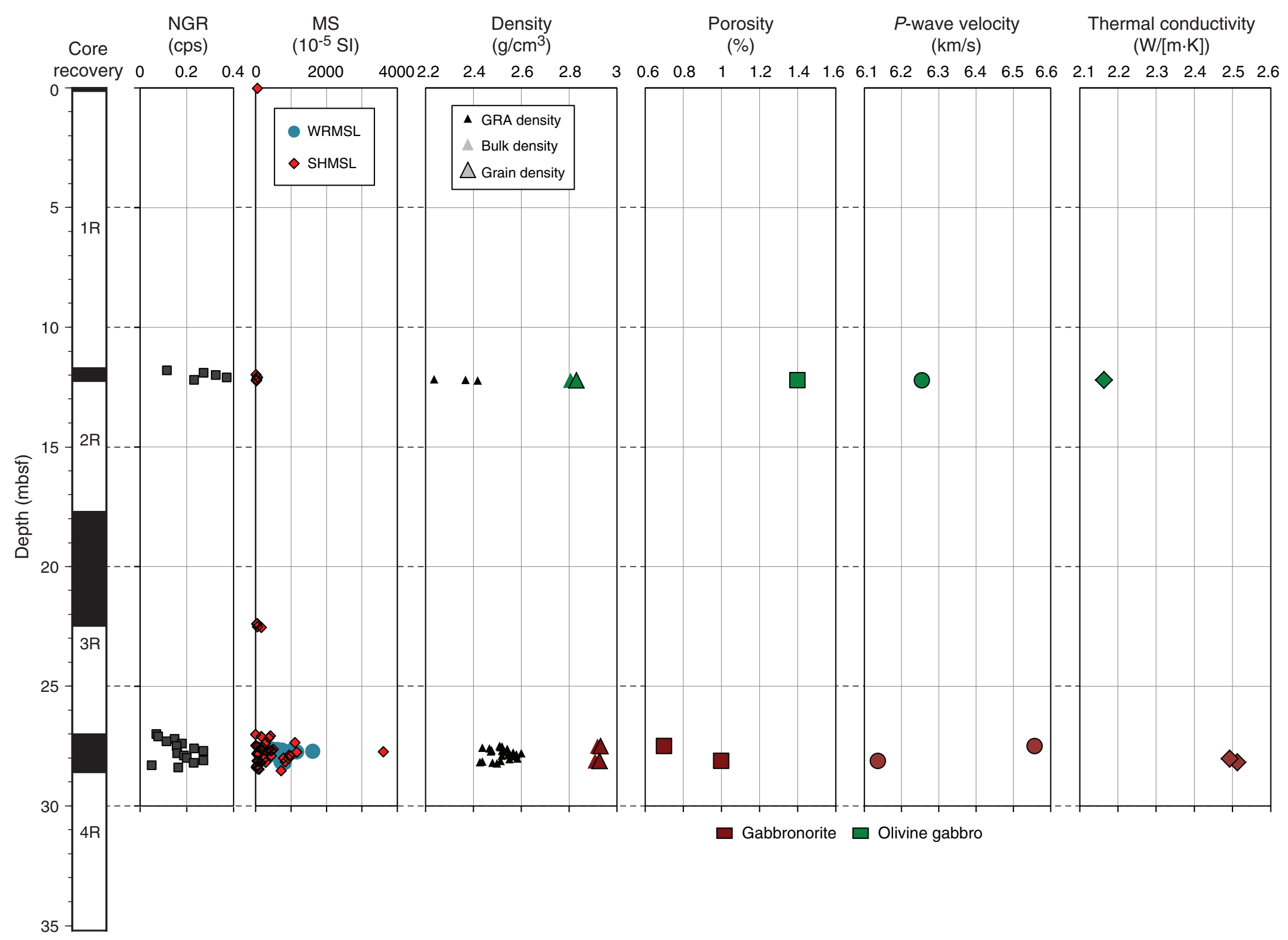


Figure F32. A-C. Color reflectance measurements, interval 345-U1415I-4R-1, 47-125 cm. Light colors $\left(\mathrm{a}^{*}=\right.$ pink, $b^{*}=$ light blue, $L^{*}=$ gray) indicate measurements made before the drifting behavior of the photospectrometer was fixed (see "Physical properties" in the "Methods" chapter [Gillis et al., 2014e]). Dark colors (a* $=$ red, $\mathrm{b}^{*}=$ blue, $\mathrm{L}^{*}=$ black) indicate data acquired after the drifting behavior of the photospectrometer was fixed.
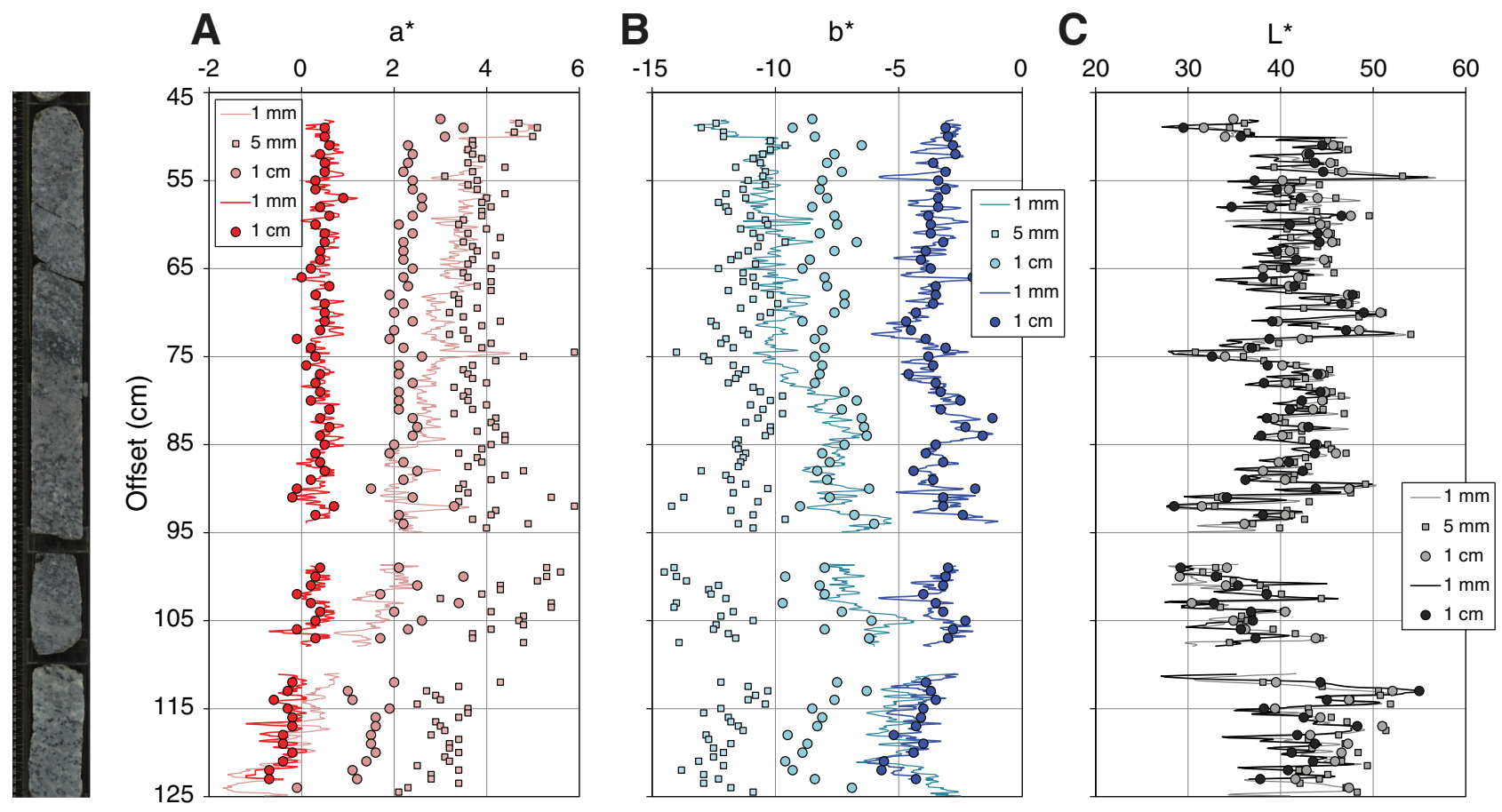
Figure F33. $P$-wave velocity vs. grain density in Hole U1415I compared with previous data from gabbroic rocks from Ocean Drilling Program (ODP) Legs 118 and 176 Hole 735B at the Southwest Indian Ridge, the Mid-Atlantic Ridge at Kane area, the Mid-Atlantic Ridge in the $15^{\circ} \mathrm{N}$ area, Expedition 304/305 Site U1309 (Atlantis Massif) on the Mid-Atlantic Ridge at $30^{\circ} \mathrm{N}$, and Hess Deep at ODP Leg 147 Site 894 (Shipboard Scientific Party, 1989, 1993, 1995, 1999, 2004; Expedition 304/305 Scientists, 2006). The locations of slow-spreading crust hole, site, or leg numbers on the plot indicate average values.

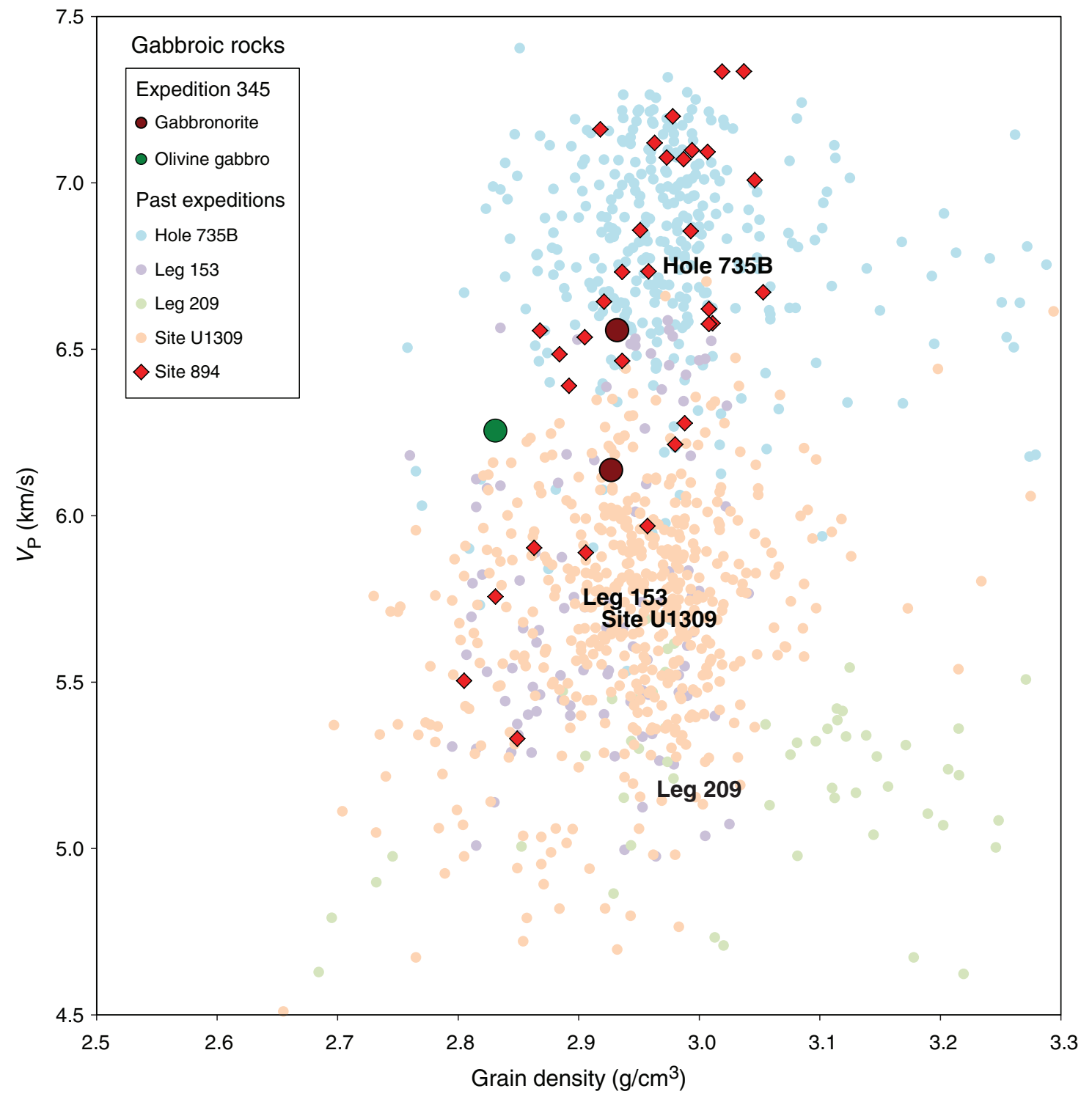


Table T1. Operations summary, Hole U1415I.

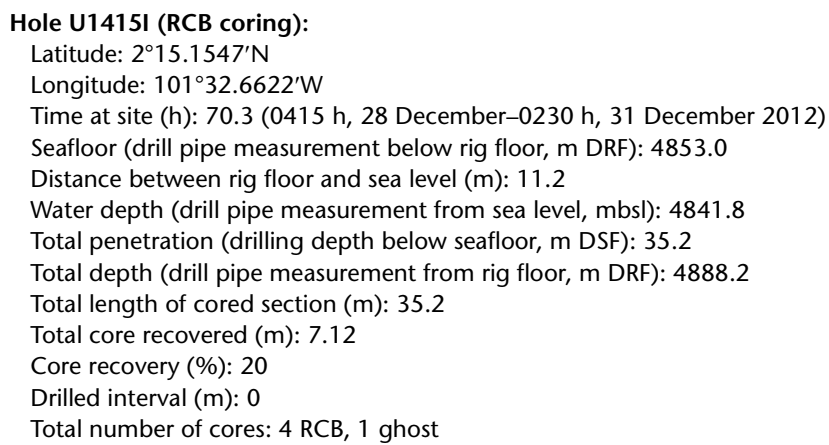

\begin{tabular}{|c|c|c|c|c|c|c|c|c|}
\hline \multirow[b]{2}{*}{ Core } & \multicolumn{2}{|c|}{ Depth (mbsf) } & \multirow{2}{*}{$\begin{array}{l}\text { Interval } \\
\text { cored } \\
(\mathrm{m})\end{array}$} & \multirow{2}{*}{$\begin{array}{l}\text { Core } \\
\text { recovered } \\
(\mathrm{m})\end{array}$} & \multirow{2}{*}{$\begin{array}{l}\text { Curated } \\
\text { length } \\
\text { (m) }\end{array}$} & \multirow[b]{2}{*}{$\begin{array}{c}\text { Recovery } \\
(\%)\end{array}$} & \multirow[b]{2}{*}{$\begin{array}{l}\text { Date } \\
(2012)\end{array}$} & \multirow[b]{2}{*}{$\begin{array}{c}\text { Time UTC } \\
(\mathrm{h})\end{array}$} \\
\hline & $\begin{array}{c}\text { Top of cored } \\
\text { interval }\end{array}$ & $\begin{array}{c}\text { Bottom of } \\
\text { cored interval }\end{array}$ & & & & & & \\
\hline \multicolumn{9}{|c|}{ 345-U1415I- } \\
\hline $1 \mathrm{R}$ & 0.0 & 11.7 & 11.7 & 0.16 & 0.15 & 1 & $29 \mathrm{Dec}$ & 1645 \\
\hline $2 \mathrm{R}$ & 11.7 & 17.7 & 6.0 & 0.56 & 0.58 & 9 & $29 \mathrm{Dec}$ & 2100 \\
\hline $3 R$ & 17.7 & 27.0 & 9.3 & 4.80 & 4.87 & 52 & $30 \mathrm{Dec}$ & 0550 \\
\hline $4 \mathrm{R}$ & 27.0 & 35.2 & 8.2 & 1.60 & 1.60 & 20 & $30 \mathrm{Dec}$ & 1455 \\
\hline \multirow[t]{2}{*}{$5 G$} & 0.0 & 5.0 & 0.0 & 0.21 & 0.24 & - & $30 \mathrm{Dec}$ & 1645 \\
\hline & & Total: & 35.2 & 7.12 & 7.20 & 20 & & \\
\hline
\end{tabular}

Local ship time was UTC $-7 \mathrm{~h}$. Ghost core $(G)$ is not included in totals. DRF = drilling depth below rig floor, DSF = drilling depth below seafloor. $\mathrm{R}=$ rotary core barrel $(\mathrm{RCB})$ system. $-=$ not calculated. 
Table T2. Summary of lithologic intervals and their classification into units, Hole U1415I. (Continued on next page.)

\begin{tabular}{|c|c|c|c|c|c|c|c|c|c|c|}
\hline \multirow[b]{2}{*}{ Unit } & \multirow[b]{2}{*}{ Description } & \multirow{2}{*}{$\begin{array}{l}\text { Core, section, } \\
\text { interval }(\mathrm{cm})\end{array}$} & \multicolumn{2}{|c|}{ Depth (mbsf) } & \multirow[b]{2}{*}{ Pieces } & \multirow{2}{*}{$\begin{array}{l}\text { Lithologic } \\
\text { interval }\end{array}$} & \multirow[b]{2}{*}{ Contact type } & \multirow{2}{*}{$\begin{array}{c}\text { Contact } \\
\text { definition }\end{array}$} & \multirow[b]{2}{*}{ Complete lithology name } & \multirow[b]{2}{*}{ Modal grain size } \\
\hline & & & Top & Bottom & & & & & & \\
\hline & & 345-U1415I- & & & & & & & & \\
\hline \multirow[t]{8}{*}{1} & Surficial rubble & 1R-1A, 0-12 & 0.00 & 0.12 & $1,2,3$ & 1 & Not recovered & & Orthopyroxene-bearing gabbro & Medium grained \\
\hline & & $1 \mathrm{R}-1 \mathrm{~A}, 12-15$ & 0.12 & 0.15 & 4 & 2 & Not recovered & & Gabbro & Medium grained \\
\hline & & $2 \mathrm{R}-1 \mathrm{~A}, 0-57.5$ & 11.70 & 12.28 & $\begin{array}{c}1,2,3,4,5 \\
6,7,8,9 \\
10,11\end{array}$ & 3 & Not recovered & & Orthopyroxene-bearing olivine gabbro & Medium grained \\
\hline & & $3 R-1 A, 0-150$ & 17.70 & 19.20 & & 4 & Not recovered & & Drilling-induced disaggregated gabbro & \\
\hline & & $3 R-2 A, 0-150$ & 19.20 & 20.70 & & 5 & Not recovered & & Drilling-induced disaggregated gabbro & \\
\hline & & $3 R-3 A, 0-150$ & 20.70 & 22.20 & & 6 & Not recovered & & Drilling-induced disaggregated gabbro & \\
\hline & & $3 R-4 A, 0-14$ & 22.20 & 22.34 & 1 & 7 & Not recovered & & Drilling-induced disaggregated gabbro & \\
\hline & & $3 R-4 A, 14-37$ & 22.34 & 22.57 & $2,3,4$ & 8 & Not recovered & & Gabbro & Medium grained \\
\hline \multirow[t]{17}{*}{ II } & Layered Gabbro & $4 R-1 A, 0-5$ & 27.00 & 27.05 & 1 & 9 & Not recovered & & Anorthositic olivine gabbro & Medium grained \\
\hline & Series & 4R-1A, 5-10 & 27.05 & 27.10 & 2 & 10 & Not recovered & & Olivine gabbro & Coarse grained \\
\hline & & $4 \mathrm{R}-1 \mathrm{~A}, 10-13.5$ & 27.10 & 27.14 & 2 & 11 & Not recovered & & Olivine-bearing gabbronorite & Medium grained \\
\hline & & 4R-1A, $13.5-19.5$ & 27.14 & 27.20 & 3 & 12 & Not recovered & & Orthopyroxene-bearing olivine gabbro & Medium grained \\
\hline & & 4R-1A, $19.5-24$ & 27.20 & 27.24 & 4 & 13 & Not recovered & & Olivine gabbro & Medium grained \\
\hline & & 4R-1A, 24-33 & 27.24 & 27.33 & 5 & 14 & Not recovered & & Orthopyroxene-bearing olivine gabbro & Medium grained \\
\hline & & $4 R-1 A, 33-38$ & 27.33 & 27.38 & 6 & 15 & Not recovered & & Troctolitic olivine gabbro & Medium grained \\
\hline & & $4 R-1 A, 38-63$ & 27.38 & 27.63 & $6,7,8$ & 16 & Modal, textural & Sharp & Olivine-bearing gabbronorite & Medium grained \\
\hline & & $4 \mathrm{R}-1 \mathrm{~A}, 63-74$ & 27.63 & 27.74 & 8 & 17 & Modal, textural & Sharp & Olivine gabbro & Medium grained \\
\hline & & $4 \mathrm{R}-1 \mathrm{~A}, 74-76$ & 27.74 & 27.76 & 8 & 18 & Modal, textural, grain size & Sharp & Troctolite & Coarse grained \\
\hline & & $4 R-1 A, 76-87$ & 27.76 & 27.87 & 8 & 19 & Modal, textural, grain size & Sharp & Olivine-bearing gabbronorite & Medium grained \\
\hline & & 4R-1A, 87-104 & 27.87 & 28.04 & 8,9 & 20 & Modal & Sharp & Orthopyroxene-bearing olivine gabbro & Medium grained \\
\hline & & 4R-1A, 104-110 & 28.04 & 28.10 & 9 & 21 & Modal, textural & Sharp & Olivine-bearing gabbronorite & Medium grained \\
\hline & & $4 R-1 A, 110-143$ & 28.10 & 28.43 & $10,11,12$ & 22 & Not recovered & & Gabbronorite & Medium grained \\
\hline & & $4 \mathrm{R}-2 \mathrm{~A}, 0-8.5$ & 28.43 & 28.52 & 1 & 23 & Not recovered & & Olivine-bearing gabbro & Medium grained \\
\hline & & $4 \mathrm{R}-2 \mathrm{~A}, 8.5-13$ & 28.52 & 28.56 & 2 & 24 & Not recovered & & Clinopyroxene-bearing troctolite & Medium grained \\
\hline & & $4 \mathrm{R}-2 \mathrm{~A}, 13-17$ & 28.56 & 28.60 & 3 & 25 & Not recovered & & Anorthositic gabbro & Medium grained \\
\hline \multirow{4}{*}{$\begin{array}{l}\text { Ghost } \\
\text { cores }\end{array}$} & Samples recovered & $5 \mathrm{G}-1 \mathrm{~A}, 0-4$ & 6.00 & 6.04 & 1 & G1 & Not recovered & & Olivine gabbro & Medium grained \\
\hline & from previously & $5 \mathrm{G}-1 \mathrm{~A}, 4-12.5$ & 6.04 & 6.13 & 2 & G2 & Not recovered & & Completely altered felsic material & Coarse grained \\
\hline & core intervals while & $5 \mathrm{G}-1 \mathrm{~A}, 12.5-18$ & 6.13 & 6.18 & 3 & G3 & Not recovered & & Clinopyroxene oikocryst-bearing troctolite & Coarse grained \\
\hline & cleaning the hole & $5 G-1 A, 18-24.5$ & 6.18 & 6.25 & 4 & G4 & Not recovered & & Anorthositic gabbro & Medium grained \\
\hline
\end{tabular}




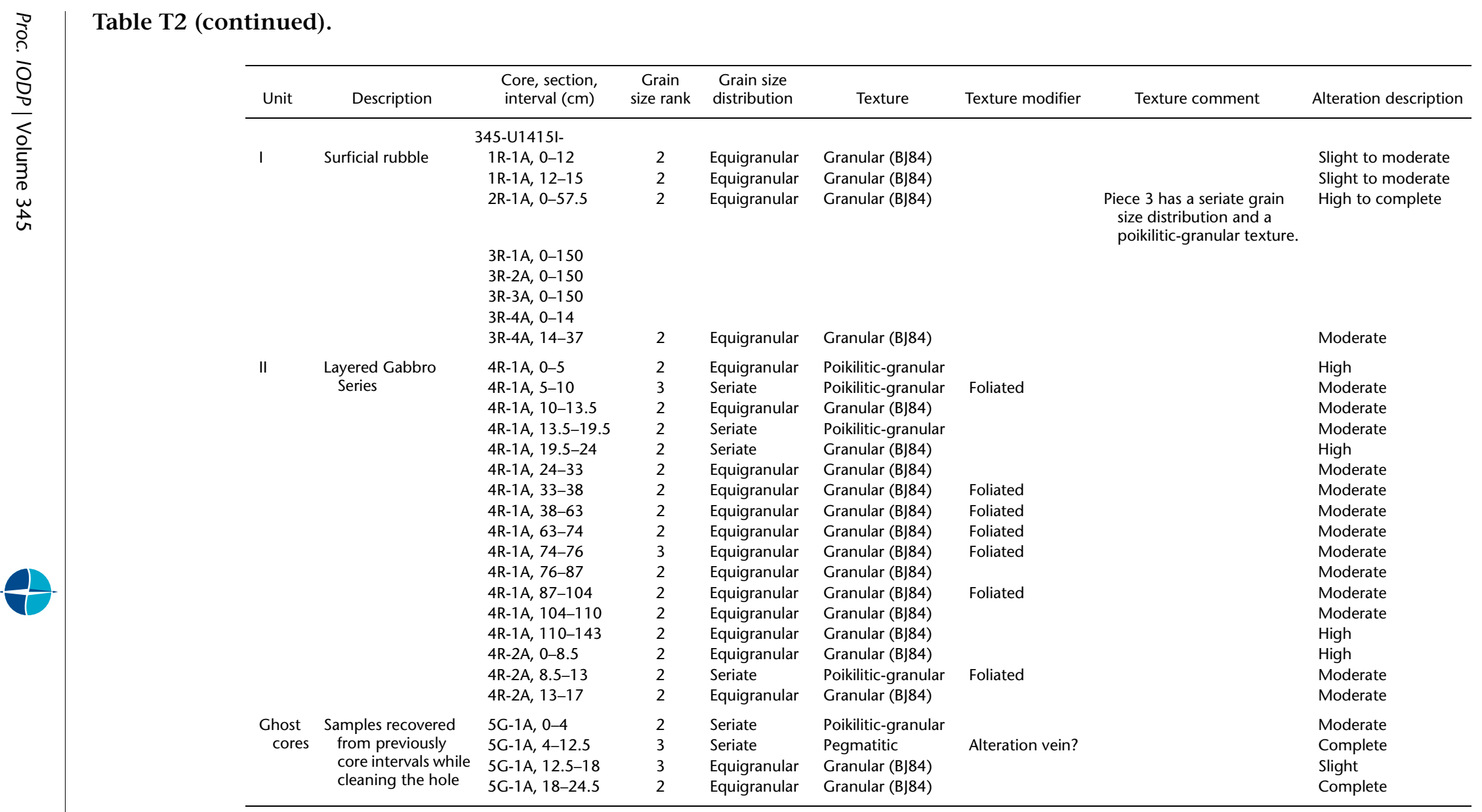


Table T3. Details and explanations for thin sections with two igneous domains, Hole U1415I.

\begin{tabular}{|c|c|c|c|c|c|c|c|c|c|}
\hline $\begin{array}{l}\text { Core, section, } \\
\text { interval }(\mathrm{cm})\end{array}$ & $\begin{array}{l}\text { Thin section } \\
\text { number }\end{array}$ & $\begin{array}{l}\text { Lithologic } \\
\text { interval }\end{array}$ & Rock name & Rock comment & Nature of domains & Contact & $\begin{array}{c}\text { Number } \\
\text { of } \\
\text { domains }\end{array}$ & $\begin{array}{l}\text { Igneous } \\
\text { domain }\end{array}$ & $\begin{array}{c}\text { Domain lithology } \\
\text { name }\end{array}$ \\
\hline \multicolumn{10}{|l|}{ 345-U1415I- } \\
\hline 4R-2W, 9-13 (Piece 2) & 19 (image) & 24 & $\begin{array}{l}\text { Clinopyroxene oikocryst- } \\
\text { bearing troctolite }\end{array}$ & $\begin{array}{l}\text { Contains a } 2 \mathrm{~cm} \\
\text { clinopyroxene } \\
\text { oikocryst }\end{array}$ & Oikocrysts/Matrix & Sutured & 2 & $\begin{array}{l}1 \\
2\end{array}$ & $\begin{array}{l}\text { Troctolite } \\
\text { Clinopyroxene oikocryst }\end{array}$ \\
\hline 4R-1W, 35-38 (Piece 6) & 21 (image) & $15 / 16$ & $\begin{array}{l}\text { Contact between } \\
\text { troctolitic olivine } \\
\text { gabbro and olivine- } \\
\text { bearing gabbro }\end{array}$ & $\begin{array}{l}\text { Contact between Interval } \\
15 \text { and } 16\end{array}$ & $\begin{array}{l}\text { Contact between two } \\
\text { lithologic intervals }\end{array}$ & Sutured & 2 & $\begin{array}{l}1 \\
2\end{array}$ & $\begin{array}{l}\text { Troctolitic olivine gabbro } \\
\text { Olivine-bearing gabbro }\end{array}$ \\
\hline
\end{tabular}


Table T4. Modal proportions for grain mounts of drilling-induced disaggregated gabbro cuttings (Intervals 47), Hole U1415I.

\begin{tabular}{|c|c|c|c|c|c|c|}
\hline \multirow[b]{2}{*}{ Mineral } & \multicolumn{2}{|c|}{ 345-U1415I-3R-1, TS 15} & \multicolumn{2}{|c|}{ 345-U1415I-3R-1, TS 16} & \multicolumn{2}{|c|}{ 345-U1415I-3R-1, TS 17} \\
\hline & $\begin{array}{l}\text { Modal } \\
(\%)\end{array}$ & $\begin{array}{l}\text { Reconstructed } \\
\text { igneous mode }\end{array}$ & $\begin{array}{l}\text { Modal } \\
(\%)\end{array}$ & $\begin{array}{l}\text { Reconstructed } \\
\text { igneous mode }\end{array}$ & $\begin{array}{l}\text { Modal } \\
(\%)\end{array}$ & $\begin{array}{l}\text { Reconstructed } \\
\text { igneous mode }\end{array}$ \\
\hline Plagioclase & 20 & 64.3 & 17 & 57 & 24 & 62.8 \\
\hline Pyroxene & 16 & 31.2 & 16 & 31 & 14 & 30.0 \\
\hline Amphibole after pyroxene & 10 & & 12 & & 11 & \\
\hline Polycrystalline amphibole & 2 & & 6 & & 3 & \\
\hline Secondary plagioclase & 13 & & 13 & & 10 & \\
\hline Zeolite (including veins and plagioclase replacement) & 7 & & 3 & & 3 & \\
\hline Cataclasite & 12 & & 7 & & 12 & \\
\hline Bruised grain of plagioclase or pyroxene & 2 & & 0.6 & & 0.8 & \\
\hline Prehnite vein/Prehnite replacing cataclasite & 5 & & 5 & & 5 & \\
\hline Prehnite replacing plagioclase & 3 & & 7 & & 4 & \\
\hline Chlorite & 4 & & 6 & & 5 & \\
\hline Olivine & & 4 & 0.4 & 12 & & 7 \\
\hline Clay & 1 & & 3 & & 3 & \\
\hline Serpentine & & & 0.2 & & & \\
\hline Sulfide & 0.4 & 0.4 & & & & \\
\hline Volcanic clasts & 2 & 0.0 & 3 & 0 & 5 & 0.0 \\
\hline $\begin{array}{l}\text { Cataclastic (excluding volcanics, including prehnite } \\
\text { replacing cataclasite) }\end{array}$ & 20 & & 13 & & 19 & \\
\hline Altered & 48 & & 58 & & 47 & \\
\hline
\end{tabular}

More than 450 points counted in each slide. Igneous mode is estimated according to the following formula: plagioclase $=$ plagioclase + secondary plagioclase + zeolite + prehnite $+($ cataclasite + bruised grains $) \times 0.7+$ chlorite $\times 0.8$; pyroxene (includes some orthopyroxene $)=$ pyroxene + amphibole after pyroxene + (cataclasite + bruised grains $) \times 0.3$; olivine $=$ olivine + clay minerals + serpentine + polycrystalline amphibole + chlorite $\times 0.2$. The coefficients are derived as follows: cataclasites and bruised grains are assumed to be $70 \%$ plagioclase and $30 \%$ pyroxene; chlorite is assumed to be $80 \%$ replacing plagioclase and $20 \%$ replacing olivine; prehnite is assumed to be replacing plagioclase; clay and serpentine are $100 \%$ replacing olivine. TS $=$ thin section . 


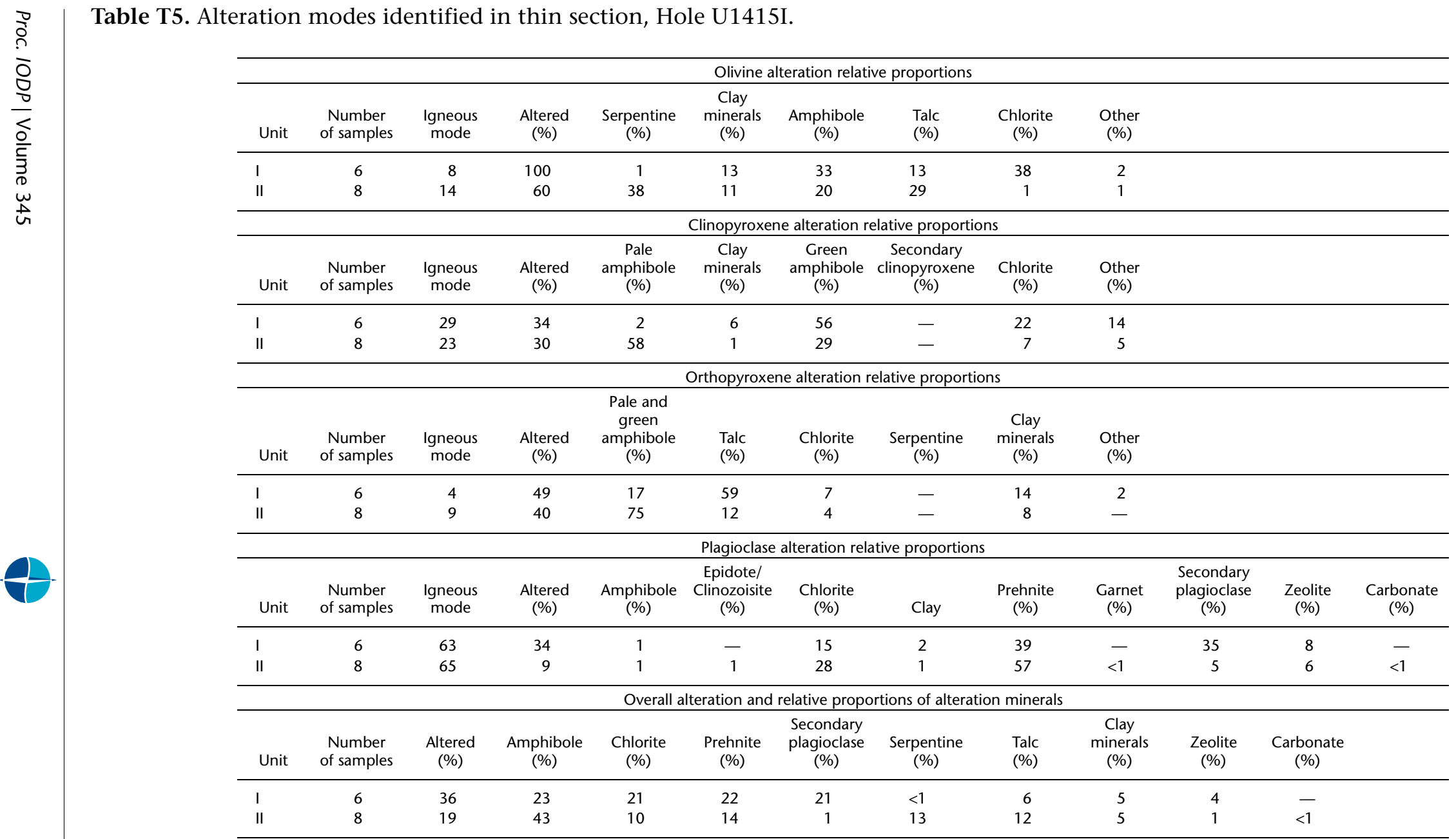

$-=$ not identified . 
Table T6. Results from X-ray diffraction analyses of drilling-induced disaggregated gabbro cuttings and veinfilling material, Hole U1415I.

\begin{tabular}{|c|c|c|c|c|c|}
\hline \multirow{2}{*}{$\begin{array}{l}\text { Core, } \\
\text { section }\end{array}$} & \multicolumn{2}{|c|}{ Depth (mbsf) } & \multirow[b]{2}{*}{ Sample ID } & \multirow[b]{2}{*}{ Primary phase } & \multirow{2}{*}{$\begin{array}{c}\text { Secondary } \\
\text { phases }\end{array}$} \\
\hline & Top & Bottom & & & \\
\hline \multicolumn{6}{|c|}{ 345-U1415I- } \\
\hline $3 \mathrm{R}-1 \mathrm{~W}$ & 18.08 & 18.13 & OTHR4562691 & $\mathrm{An}_{80}$ plagioclase, clinopyroxene, amphibole, & Clinochlor \\
\hline $3 \mathrm{R}-2 \mathrm{~W}$ & 19.90 & 19.96 & OTHR4562721 & $\mathrm{An}_{80}$ plagioclase, clinopyroxene, amphibole, & Clinochlor \\
\hline $3 R-3 W$ & 21.42 & 21.47 & OTHR4562751 & $\mathrm{An}_{80}$ plagioclase, clinopyroxene, amphibole, & Clinochlor \\
\hline $5 G-1 W$ & 0.09 & 0.12 & OTHR4576181 & Prehnite & \\
\hline
\end{tabular}


Table T7. $P$-wave velocity, density, and porosity measurements, Hole U1415I.

\begin{tabular}{|c|c|c|c|c|c|c|c|c|c|c|c|c|c|c|c|c|}
\hline \multirow{3}{*}{$\begin{array}{l}\text { Core, section, } \\
\text { interval }(\mathrm{cm})\end{array}$} & \multirow{3}{*}{$\begin{array}{l}\text { Depth } \\
\text { (mbsf) }\end{array}$} & \multicolumn{11}{|c|}{$P$-wave velocity } & \multirow{3}{*}{$\begin{array}{l}\text { Bulk } \\
\text { density } \\
\left(\mathrm{g} / \mathrm{cm}^{3}\right)\end{array}$} & \multirow{3}{*}{$\begin{array}{l}\text { Grain } \\
\text { density } \\
\left(\mathrm{g} / \mathrm{cm}^{3}\right)\end{array}$} & \multirow{3}{*}{$\begin{array}{l}\text { Porosity } \\
\text { (vol\%) }\end{array}$} & \multirow[b]{3}{*}{ Primary lithology } \\
\hline & & \multicolumn{3}{|c|}{ Mean $(\mathrm{km} / \mathrm{s})$} & \multicolumn{3}{|c|}{ Standard deviation $(\mathrm{km} / \mathrm{s})$} & \multicolumn{3}{|c|}{ Standard deviation (\%) } & \multirow{2}{*}{$\begin{array}{l}\text { Mean } \\
(\mathrm{km} / \mathrm{s})\end{array}$} & \multirow{2}{*}{$\begin{array}{c}\text { Apparent } \\
\text { anisotropy } \\
(\%)\end{array}$} & & & & \\
\hline & & $x$ & $y$ & $z$ & $x$ & y & $z$ & $x$ & $y$ & $z$ & & & & & & \\
\hline \multicolumn{17}{|l|}{ 345-U1415I- } \\
\hline $2 \mathrm{R}-1 \mathrm{~W}, 51-53$ & 12.22 & 6.26 & 6.31 & 6.16 & 0.0025 & 0.0019 & 0.0033 & 0.04 & 0.03 & 0.05 & 6.24 & 2.5 & & & & Orthopyroxene-bearing olivine gabbro \\
\hline $2 \mathrm{R}-1 \mathrm{~W}, 51-53$ & 12.22 & 6.23 & 6.33 & 6.26 & 0.0030 & 0.0041 & 0.0014 & 0.05 & 0.06 & 0.02 & 6.28 & 1.6 & & & & Orthopyroxene-bearing olivine gabbro \\
\hline $2 \mathrm{R}-1 \mathrm{~W}, 51-53$ & 12.22 & 6.24 & 6.32 & 6.20 & 0.0147 & 0.0121 & 0.0513 & 0.24 & 0.19 & 0.83 & 6.26 & 2.0 & 2.81 & 2.83 & 1.4 & Orthopyroxene-bearing olivine gabbro \\
\hline $4 \mathrm{R}-1 \mathrm{~W}, 50-52$ & 27.505 & 6.44 & 6.62 & 6.56 & 0.0065 & 0.0015 & 0.0008 & 0.10 & 0.02 & 0.01 & 6.54 & 2.8 & & & & Olivine-bearing gabbronorite \\
\hline $4 R-1 W, 50-52$ & 27.505 & 6.66 & 6.63 & 6.43 & 0.0074 & 0.0006 & 0.0157 & 0.11 & 0.01 & 0.24 & 6.57 & 3.4 & & & & Olivine-bearing gabbronorite \\
\hline $4 \mathrm{R}-1 \mathrm{~W}, 50-52$ & 27.505 & 6.55 & 6.63 & 6.50 & 0.1140 & 0.0057 & 0.0685 & 1.74 & 0.09 & 1.05 & 6.56 & 2.0 & 2.92 & 2.93 & 0.7 & Olivine-bearing gabbronorite \\
\hline $4 \mathrm{R}-1 \mathrm{~W}, 112-114$ & 28.125 & 6.01 & 6.26 & 6.20 & 0.0015 & 0.0033 & 0.0036 & 0.03 & 0.05 & 0.06 & 6.16 & 4.2 & & & & Gabbronorite \\
\hline $4 \mathrm{R}-1 \mathrm{~W}, 112-114$ & 28.125 & 5.95 & 6.22 & 6.18 & 0.0024 & 0.0041 & 0.0036 & 0.04 & 0.07 & 0.06 & 6.12 & 4.4 & & & & Gabbronorite \\
\hline \multirow[t]{3}{*}{$4 \mathrm{R}-1 \mathrm{~W}, 112-114$} & 28.125 & 5.98 & 6.24 & 6.19 & 0.0291 & 0.0233 & 0.0095 & 0.49 & 0.37 & 0.15 & 6.14 & 4.3 & 2.91 & 2.93 & 1.0 & Gabbronorite \\
\hline & & & & & & & & \multirow{2}{*}{\multicolumn{3}{|c|}{$\begin{array}{r}\text { Mean: } \\
\text { Standard deviation: }\end{array}$}} & 6.32 & 2.79 & 2.88 & 2.90 & 1.03 & \\
\hline & & & & & & & & & & & 0.22 & 1.33 & 0.06 & 0.06 & 0.35 & \\
\hline
\end{tabular}

\begin{tabular}{lccl}
\hline $\begin{array}{c}\text { Core, section, } \\
\text { interval (cm) }\end{array}$ & $\begin{array}{c}\text { Depth } \\
(\mathrm{mbsf})\end{array}$ & $\begin{array}{c}\text { Background } \\
\text { alteration } \\
(\%)\end{array}$ & \multicolumn{1}{c}{ Comment } \\
\hline 345-U1415I- & & & \\
2R-1W, 51-53 & 12.22 & $>90$ & $V_{\mathrm{p}}$ measured Series 1 \\
2R-1W, 51-53 & 12.22 & $>90$ & $V_{\mathrm{p}}$ measured Series 2 \\
2R-1W, 51-53 & 12.22 & $>90$ & $V_{\mathrm{p}}$ measured Series 1 and 2 \\
4R-1W, 50-52 & 27.505 & $30-60$ & $V_{\mathrm{p}}$ measured Series 1 \\
4R-1W, 50-52 & 27.505 & $30-60$ & $V_{\mathrm{p}}$ measured Series 2 \\
4R-1W, 50-52 & 27.505 & $30-60$ & $V_{\mathrm{p}}$ measured Series 1 and 2 \\
4R-1W, 112-114 & 28.125 & $60-90$ & $V_{\mathrm{p}}$ measured Series 1 \\
4R-1W, 112-114 & 28.125 & $60-90$ & $V_{\mathrm{p}}$ measured Series 2 \\
4R-1W, 112-114 & 28.125 & $60-90$ & $V_{\mathrm{p}}$ measured Series 1 and 2 \\
\hline
\end{tabular}


Table T8. Thermal conductivity measurements, Hole U1415I.

\begin{tabular}{|c|c|c|c|c|c|c|c|c|}
\hline Core, section & $\begin{array}{l}\text { Depth } \\
\text { (mbsf) }\end{array}$ & $\begin{array}{c}\text { Number of } \\
\text { measurements }\end{array}$ & $\begin{array}{l}\text { Thermal } \\
\text { conductivity } \\
(\mathrm{W} /[\mathrm{m} \cdot \mathrm{K}])\end{array}$ & $\begin{array}{c}\text { Standard } \\
\text { deviation } \\
(\mathrm{W} /[\mathrm{m} \cdot \mathrm{K}])\end{array}$ & $\begin{array}{c}\text { Standard } \\
\text { deviation } \\
(\%)\end{array}$ & $\begin{array}{c}\text { Apparent } \\
\text { anisotropy } \\
(\%)\end{array}$ & Lithology & Comment \\
\hline \multicolumn{9}{|l|}{ 345-U1415I- } \\
\hline 2R-1A (Piece 11) & 12.21 & 10 & 2.164 & 0.013 & 0.62 & & Orthopyroxene-bearing olivine gabbro & Large probe \\
\hline 4R-1A (Piece 9) & 28.03 & 10 & 2.493 & 0.009 & 0.36 & & Olivine-bearing gabbronorite & Large probe \\
\hline 4R-1A (Piece 10) & 28.18 & 10 & 2.513 & 0.030 & 1.18 & & Gabbronorite & Large probe \\
\hline 4R-1A (Piece 9) & 28.03 & 6 & 2.604 & 0.033 & 1.26 & 0.3 & Olivine-bearing gabbronorite & Small probe (needle parallel to foliation) \\
\hline \multirow[t]{2}{*}{ 4R-1A (Piece 9) } & 28.03 & 9 & 2.596 & 0.039 & 1.50 & & Olivine-bearing gabbronorite & Small probe (needle perpendicular to foliation) \\
\hline & & $\begin{array}{r}\text { Mean: } \\
\text { ndard deviation: }\end{array}$ & $\begin{array}{l}2.390 \\
0.196\end{array}$ & & & & & \\
\hline
\end{tabular}

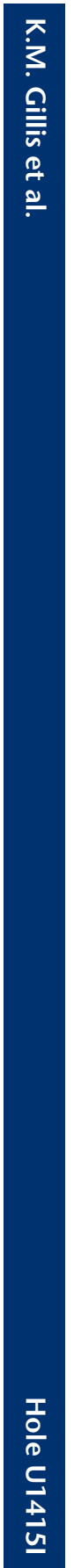

